\title{
7. CENOZOIC DIATOM BIOSTRATIGRAPHY AND PALEOCEANOGRAPHY OF THE ROCKALL PLATEAU REGION, NORTH ATLANTIC, DEEP SEA DRILLING PROJECT LEG 81 ${ }^{1}$
}

\author{
Jack G. Baldauf, U.S. Geological Survey, and Department of Paleontology, University of California, Berkeley²
}

\begin{abstract}
Diatoms are present within the Eocene to Holocene sediments recovered during Deep Sea Drilling Project (DSDP) Leg 81. A late Cenozoic, North Atlantic diatom zonation is developed as a result of the occurrence of common wellpreserved diatoms within middle Miocene to Holocene sediments. This high-latitude diatom zonation correlates with the zonation defined for the low-latitude Pacific.

Two distinct intervals of dissolution are recognized in Leg 81 sediments, a late-Miocene interval associated with the first occurrence of Thalassiosira convexa and T. miocena (6.2 m.y. ago) and a Pliocene-Pleistocene interval associated with oceanographic responses to the onset of Northern Hemisphere glaciation. Detailed analyses of the uppermost 50 $\mathrm{m}$ of Hole $552 \mathrm{~A}$ indicate that diatom abundance within sediments of the Rockall Region is primarily controlled by fluctuations in productivity resulting from latitudinal migration of water masses.
\end{abstract}

\section{INTRODUCTION}

Biostratigraphic and paleoecological studies of diatoms recovered from deep-sea sediments within the North Atlantic are quite limited when compared to the quantity of literature available concerning the diatom flora present in sediments from the North Pacific.

Few siliceous microfossil studies have been completed in the polar region of the North Atlantic. Gran (1904) published a taxonomic study of the phytoplankton of the Arctic Sea. More recently, the biostratigraphic and taxonomic studies of Schrader and Fenner (1976) and Dzinoridze et al. (1976) have been completed from sediments recovered during DSDP Leg 38 within the Norwegian-Greenland Seas.

Studies of the diatom flora in the northwestern Atlantic have been completed by Bukry (1980) for Eocene material recovered from DSDP Sites 417 and 418, Schrader (1979) for Miocene material recovered from DSDP Sites 407 and 408, and Bukry (1978a) for sediments recovered from DSDP Leg 44.

Diatoms in the surface waters of the eastern North Atlantic and the English Channel Region were recorded by Cleve (1900). Other studies within the mid-latitude Atlantic include Lohman (1941), Maynard (1976), and Pokras (1981), in which surface sediments throughout the high-latitude Atlantic were examined for fluctuations in the Pleistocene diatom assemblage. The middle Miocene diatom flora from sediments along the Atlantic margin of North America were documented by Abbott (1978) and Andrews (1978).

Numerous workers have examined the diatom flora from the equatorial Atlantic. These include the studies of Riely (1957), Kolbe (1957), Chyong Ngok (1971), Schrader (1977), and Fenner (1977). In addition, Hass and

\footnotetext{
${ }^{1}$ Roberts, D. G., Schnitker, D., et al., Init. Repts. DSDP, 81: Washington (U.S. Govt. Printing Office).

2 Address: U.S. Geological Survey, 345 Middlefield Road, Menlo Park, CA 94025.
}

Schrader (1979) and Schuette and Schrader (1981) have examined the phytoplankton within the upwelling region off northwest Africa. Furthermore, Wornardt (1974), Burckle (1977), Schrader and Gersonde (1978), Gersonde $(1979,1980)$, and Gardette (1979) have studied the diatom biostratigraphy and paleoecology of the Messinian Stage within the Mediterranean Region.

During DSDP Leg 81, four sites were drilled within the western margin of the Hatton Rockall Plateau (see Fig. 1). The presence of common diatoms in the middle to upper Miocene sediments of Site 555 and the upper Miocene to Holocene sediments of Hole 552A allows correlation of these sites with lower latitudes. Furthermore, the recovery of a well-preserved Pliocene-Pleistocene interval containing diatoms at Hole 552A makes possible the reconstruction of the paleoceanography of the North Atlantic for approximately the last 2.8 m.y.

\section{ZONATION}

Diatom zonations previously established within the mid- and high-latitude North Atlantic consist of zonal schemes developed by Schrader and Fenner (1976) and Dzinoridze et al. (1976) for the Norwegian-Greenland Sea Region, and Abbott (1978) for the continental shelf region of eastern North America. Correlation of these zones appears in Figure 2.

Although the Eocene to Holocene zonation developed by Schrader and Fenner (1976) is partially based on midlatitude oceanic species, the majority of the species used as zonal indicators are endemic to the Arctic Region. These species are not present within the Rockall Plateau Region and therefore only allow partial recognition of Schrader and Fenner's zonation.

Dzinoridze et al. (1976) developed a zonation defined by high-latitude forms such as Denticulopsis hustedtii, $D$. lauta, D. kamtschatica, D. seminae, and Thalassiosira zabelinae. Of these species, only $D$. hustedtii and $D$. lauta consistently occur within the warm-water diatom assemblage that is present in the Rockall Region, there- 


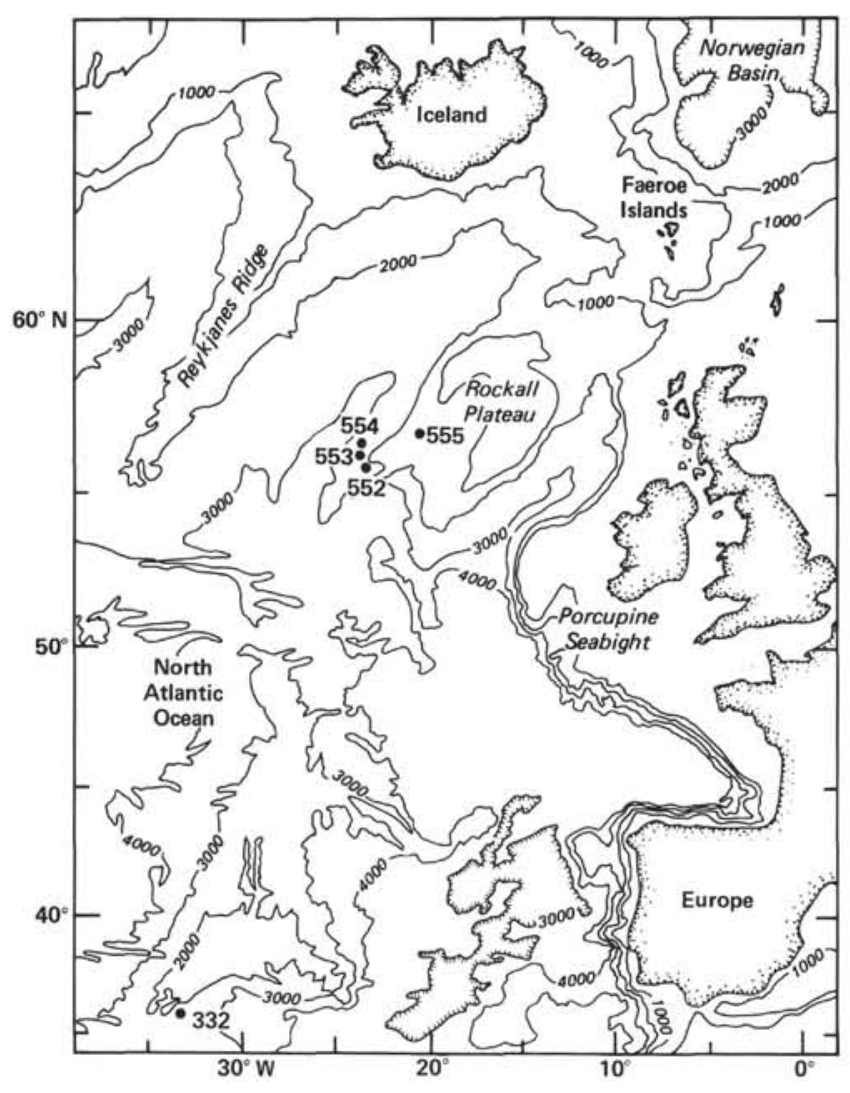

Figure 1. Location of DSDP sites cored during Leg 81 .

fore also rendering their zonation only partially useful in the warmer waters of the Rockall Region.

Similarly, the zonation developed by Abbott (1978) for the Miocene strata along the Atlantic margin of North America is only partially useful in the Rockall Region. This zonation is based primarily on shallow-water coastal forms that do not occur within Leg-81 material.

Diatoms recovered during Leg 37 (Schrader, 1977) in the low-latitude North Atlantic comprise a tropical assemblage including the species Rhizosolenia praebergonii, Nitzschia miocenica, and $N$. porteri. The diatom biostratigraphy of Leg-37 sediments is based on the diatom zonations developed by Burckle $(1969,1972)$.

The warm temperate diatom assemblage present within the late Neogene sediments recovered during Leg 81 also allows recognition and partial usage of the Partial Range Diatom Zones defined by Burckle $(1969,1972)$ for upper Miocene to Holocene sediments of the equatorial Pacific. Although the majority of the index species used to define Burckle's zones are present in the sediments recovered from the Rockall Plateau Region, the extremely rare occurrence of $R$. praebergonii and $N$. miocenica and the preservational or ecological exclusion of $N$. porteri require that Burckle's zonal scheme be modified to be useful within the Hatton-Rockall Region of the North Atlantic (see Fig. 3).

The middle Miocene interval at Site 555 contains wellpreserved diatoms and thus allows the development of a middle Miocene diatom zonation. The development of this zonation is based on the ranges of selected species present at both Sites 555 and 408 (Reykjanes Ridge, see Figs. 1 and 4).

\section{Coscinodiscus lewisianus Interval}

Author: Base, not defined; Top, Schrader (1976).

Definition: The base of this interval is not defined. The top of this interval is placed at the last occurrence of $C$. lewisianus.

Remarks. The Coscinodiscus lewisianus Interval is recognized at DSDP Sites 555, 408, and 338. No base is presently defined for this interval because of dissolution at both Sites 555 and 408 . However, lower middle Miocene sediments at Site 338 contain well-preserved diatoms that stratigraphically range from the first occurrence of Denticulopsis lauta to the last occurrence of $C$. lewisianus. Schrader and Fenner (1976) assigned Cores 338-8 through 338-11 to their middle Miocene Norwegian Sea Zones (Actinocyclus ingens to Rhizosolenia bulbosa Zones) which are based primarily on species endemic to the Norwegian Sea Region.

Recently Barron (1980a, 1981) developed a zonation that has greater geographic applicability and can be recognized at Site 338 . The presence of D. lauta, D. hyalina, D. hustedtii, $A$. ingens, Raphidodiscus marylandicus, C. plicatus, and C. lewisianus allows Cores 338-8 through 338-11 to be assigned to the Denticulopsis lauta and the Denticulopsis hustedtii-Denticulopsis lauta Zones of Barron (1980a, 1981). The Denticulopsis lauta Zone extends from the first occurrence of D. lauta in Sample $338-11-4,85-86 \mathrm{~cm}$ to the first occurrence of $D$. hustedtii recorded by Schrader and Fenner (1976) in Sample $338-11-2,85-86 \mathrm{~cm}$. The first occurrence of $D$. hyalina, which defines the Denticulopsis lauta Subzone " $a$ "/Subzone "b" boundary, is recorded in Sample 338-11-3, $85-86 \mathrm{~cm}$, although the first occurrence of $D$. lauta is recorded in Sample 338-11-4, 85-86 cm. The first occurrence of $D$. punctata, $A$. ingens, and Mederia splendida is also in this sample, suggesting that an unconformity occurs directly below this sample and that the true first occurrence of $D$. lauta is missing.

Barron (1980a, 1981) defined four subzones for the Denticulopsis hustedtii-Denticulopsis lauta Zone. However, only Subzone "a" defined as the interval from the first occurrence of $D$. hustedtii to the first occurrence of $D$. praedimorpha is recognized at Site 338 . Within the uppermost portion of this subzone, the first occurrence of $C$. plicatus and the last occurrence of $C$. lewisianus are observed (Barron, 1981).

The first occurrence of $D$. hustedtii is recorded in Sample 338-11-2, 85-86 cm. The first occurrence of $C$. plicatus and the last occurrence of $C$. lewisianus both occur in Sample 338-8-2, 10-11 cm. Because diatoms are barren above this sample the true last occurrence of $C$. lewisianus is uncertain. However, the first occurrence of $C$. plicatus within this sample suggests that the true last occurrence of $C$. lewisianus should occur only slightly above this sample.

Other useful markers within Subzone "a" are the last occurrence of $R$. marylandicus and the transition from common $D$. hyalina to common $D$. hustedtii. Both are recognized at Site 338 . The last $R$. marylandicus is re- 


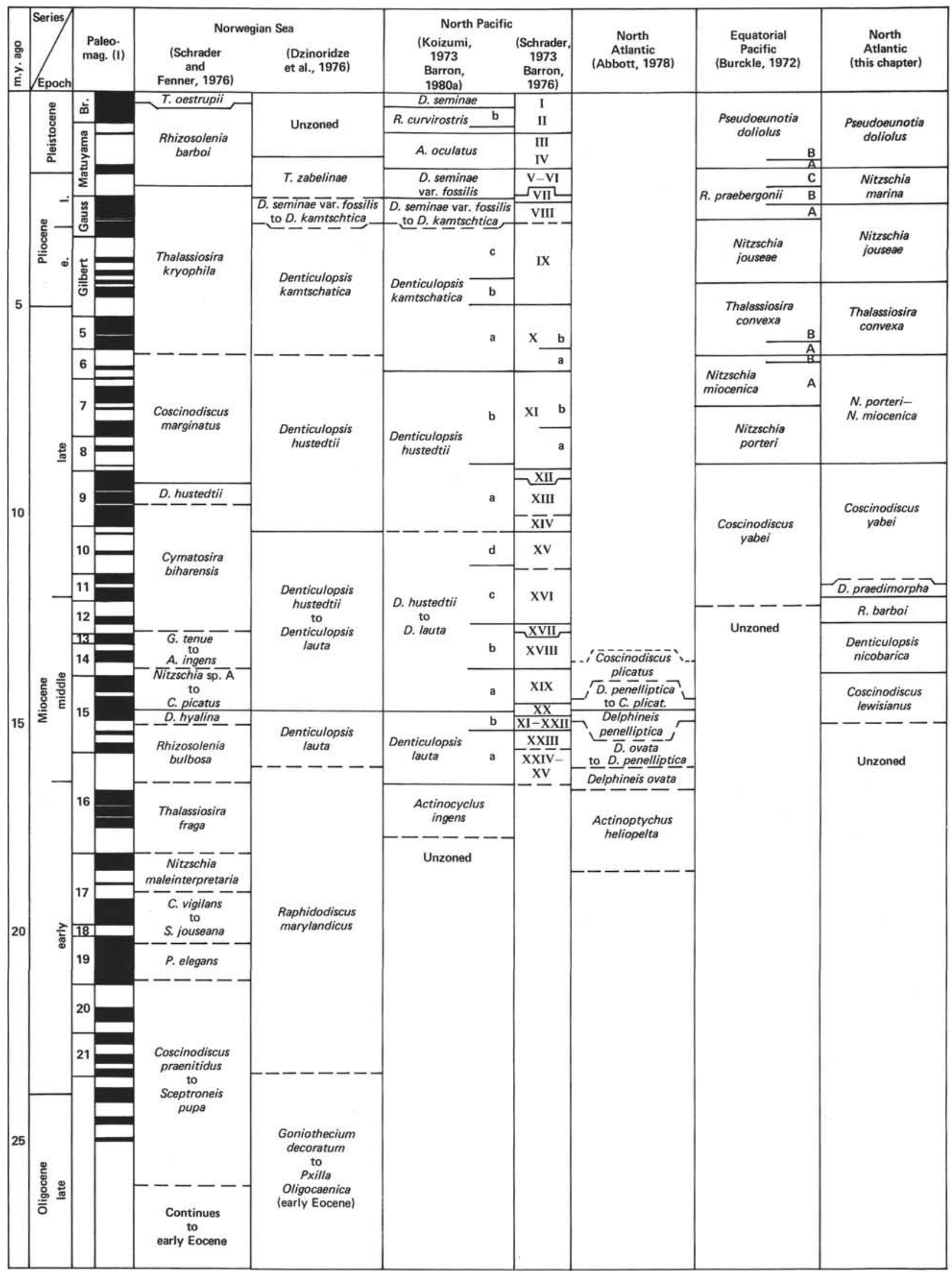

Figure 2. Correlation of the Leg 81 diatom zonation modified from Burckle (1972) with the high-latitude Norwegian Sea diatom zonations of Schrader and Fenner (1976) and Dzinoridze et al. (1976), the middle Miocene western Atlantic margin diatom zonation of Abbott (1978), and the low-latitude Pacific diatom zonation of Burckle (1972). 


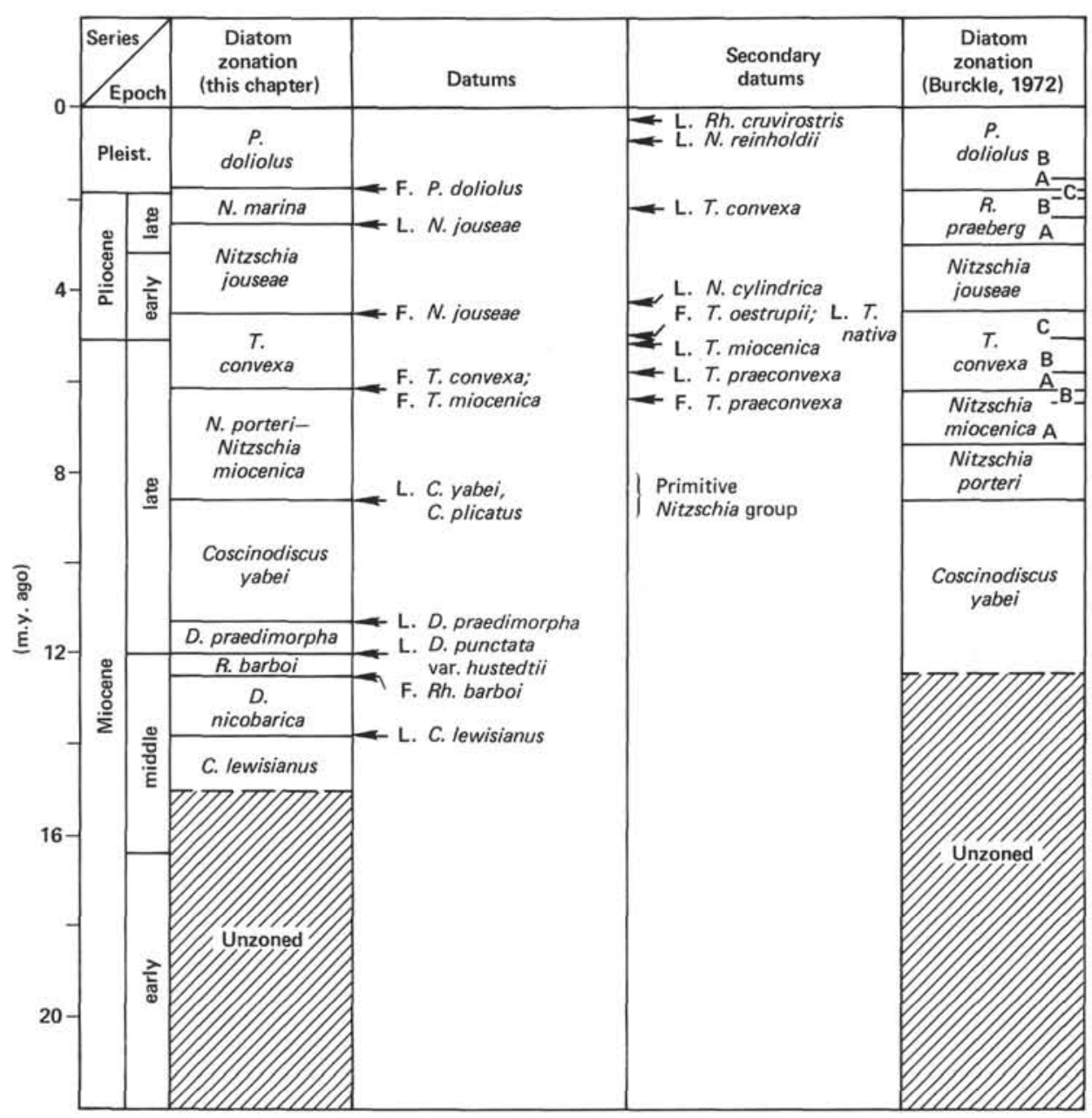

Figure 3. Correlation of the Leg 81 diatom zonation and datum levels with the equatorial Pacific diatom zonation defined by Burckle (1972).

corded in Sample 338-11-1, 65-66 cm, and the D. hyalina-D. hustedtii transition occurs at approximately Sample $338-10-1,135-136 \mathrm{~cm}$.

The ability to distinguish these zones in the Norwegian Sea allows the base of the Coscinodiscus lewisianus Interval to be tentatively placed at the first occurrence of $D$. hustedtii. However, further correlations are required to determine if this datum is time equivalent between high and middle latitudes of the Atlantic. This is especially critical since the first occurrence of $D$. lauta is diachronus between these latitudes.

$D$. lauta first occurs stratigraphically above the last occurrence of $C$. lewisianus (see Fig. 4) at both Sites 555 and 408. This stratigraphic position is similar to the first occurrence of $D$. lauta at mid-latitudes. The first occurrence of D. lauta at Site 338 is recorded stratigraphically below the first $C$. lewisianus. This stratigraphic succession is similar to that of the high-latitude Pacific.

Other floral elements: $A$. ingens, $C$. obscurus, C. plicatus, C. tabularis, C. vetustissimus, Craspedodiscus coscinodiscus, $D$. hustedtii, D. nicobarica, D. punctata, Rhizosolenia miocenica, $R$. praebarboi.

Correlation: The top of this interval approximates the middle Miocene NN6/NN7 calcareous nannofossil zonal boundary as used by Backman (this volume). The Coscinodiscus lewisianus Interval also correlates to Subzone "a" of the Denticulopsis hustedtii-Denticulopsis lauta Zone of Barron (1980a) to North Pacific Diatom Zone XXI (NPDZ XXI) of Schrader (1973), and to the Coscinodiscus lewisianus Zone of Barron (in press).

\section{Denticulopsis nicobarica Zone}

Author: Base, Schrader (1976); Top, Baldauf (this chapter).

Definition: The base of this zone is defined by the last occurrence of Coscinodiscus lewisianus. The top is defined by the first occurrence of Rhizosolenia barboi.

Remarks: This zone is recognized at both Sites 555 and 408. Useful datums within this zone include the first occurrence of Denticulopsis praedimorpha and the last occurrence of $D$. nicobarica. Schrader (1976) defined the top of his Denticulopsis nicobarica Zone by the first occurrence of $D$. hustedtii. This top has been modified here.

Other floral elements: Actinocyclus ingens, Asterolampra marylandica, C. plicatus, C. radiatus, Rossiella paleacea, $D$. praedimorpha, D. hustedtii, D. lauta, D. 


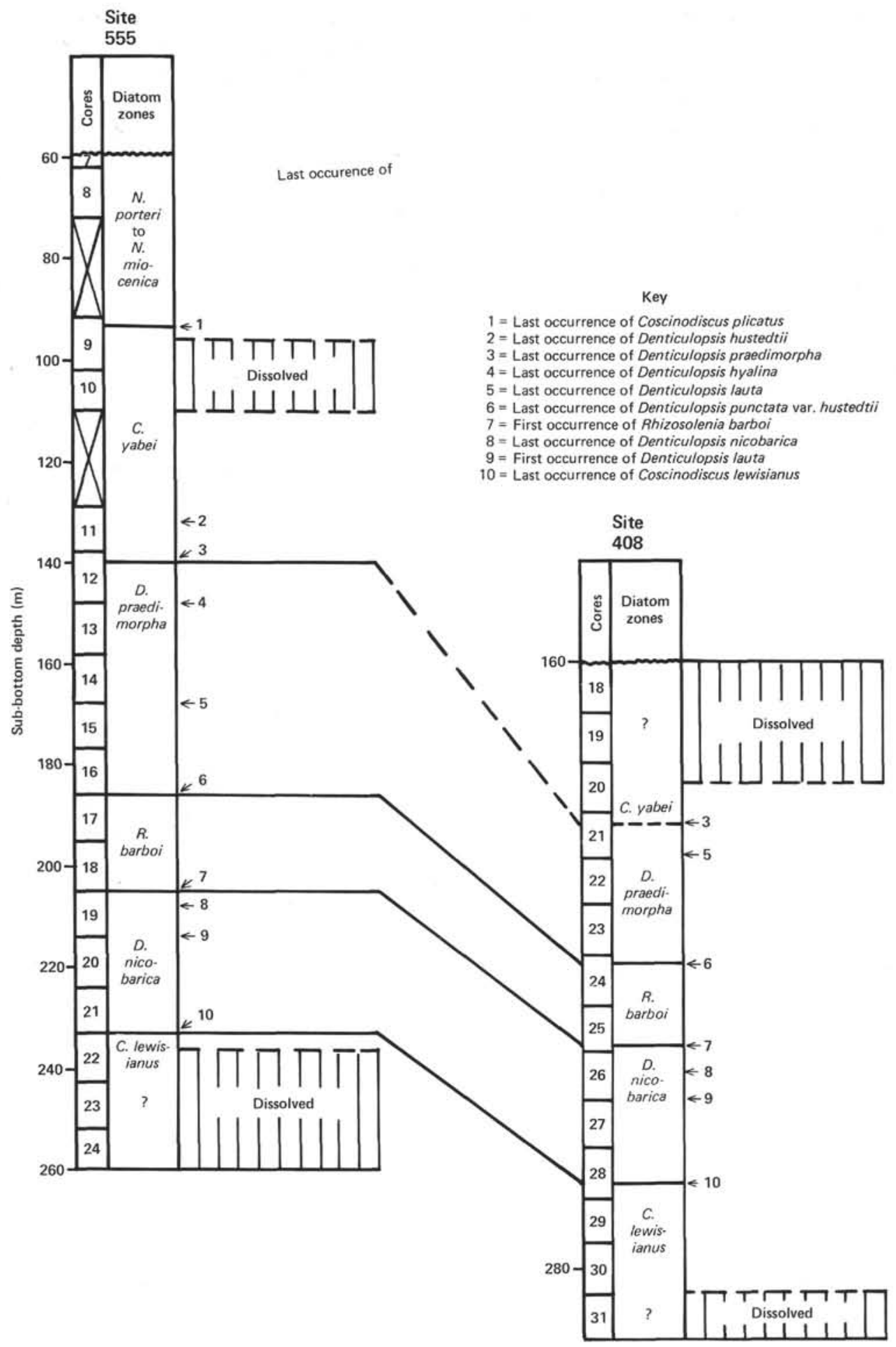

Figure 4. Comparison of stratigraphically useful datums between DSDP Sites 408 and 555.

punctata, D. punctata var. hustedtii, Rhizosolenia praebarboi, Rouxia californica, and Thalassiothrix miocenica.

Correlation: The top of this zone correlates with the lowest portion of the calcareous nannofossil Zone NN9 as recognized by Backman (this volume). The Denticulopsis nicobarica Zone correlates to Subzone " $a$ " and " b" of the Denticulopsis hustedtii-Denticulopsis lauta Zone of Barron (1980a), NPDZ XIX and XX of Schra- der (1973), and the Coscinodiscus gigas var. diorama Zone of Barron (in press).

\section{Rhizosolenia barboi Zone}

Author: Baldauf (this chapter).

Definition: The base of this zone is defined by the first occurrence of $R$. barboi. The top of this zone is 
placed at the last occurrence of Denticulopsis punctata var. hustedtii.

Remarks: This zone is recognized at both Sites 555 and 408. The first occurrence of Hemidiscus cuneiformis at Site 555 is similar to its first occurrence within the mid-latitude Pacific (Barron, 1981) and is a useful datum within this zone. The top of this zone approximates the middle Miocene/late Miocene boundary.

Other floral elements: Actinocyclus ingens, Coscinodiscus salisburyanus, C. yabei, Craspedodiscus coscinodiscus, Coscinodiscus plicatus, D. hustedtii, D. lauta, $D$. praedimorpha, and $R$. praebarboi.

Correlation: This zone correlates to the lowest portion of the Coscinodiscus yabei Zone of Burckle (1972), Subzone "c" of the Denticulopsis hustedtii-Denticulopsis lauta Zone of Barron (1980a), and the Craspedodiscus coscinodiscus Zone of Barron (in press).

\section{Denticulopsis praedimorpha Zone}

Author: Baldauf (this chapter).

Definition: The base of this zone is defined by the last occurrence of $D$. punctata var. hustedtii. The top is defined by last occurrence of $D$. praedimorpha.

Remarks: The last occurrence of $D$. punctata occurs within this zone at both Sites 555 and 408 . However, the range of $D$. punctata is stratigraphically higher at Site 555 , where the last occurrence approximates the last occurrence of $D$. praedimorpha. The last occurrence of $D$. punctata at Site 408 occurs in the middle portion of the Denticulopsis praedimorpha Zone. Therefore, the reliability of $D$. punctata as a secondary datum is doubtful. Useful datums within this zone include the first occurrence of Thalassiosira eccentrica and the last occurrence of Actinocyclus ingens, both of which occur within the upper portion of this zone. The last occurrence of $A$. ingens within this zone is equivalent to the range of this species reported from temperate latitudes of the Pacific (Schrader, 1973, and Barron, 1980a) rather than to the range of this species reported from tropical regions (see Barron, 1981).

Other floral elements: Coscinodiscus plicatus, C. salisburyanus, C. tabularis, C. vetustisimus, C. yabei, D. hyalina, Hemidiscus cuneiformis, Nitzschia praereinholdii, Rhizosolenia barboi, and Synedra jouseana.

Correlation: This zone correlates to the lower portion of the Coscinodiscus yabei Zone of Burckle (1972) and to Subzone "d" of the Denticulopsis hustedtii-Denticulopsis lauta Zone of Barron (1980a).

\section{Coscinodiscus yabei Zone} (1972).

Author: Base, Baldauf (this chapter); Top, Burckle

Definition: The base of this zone is defined by the last occurrence of Denticulopsis praedimorpha. The top of this zone is placed at the last occurrence of $C$. yabei.

Remarks: Although the top of this zone is defined by the last occurrence of $C$. yabei, the range of this species is diachronous between subtropical and temperate assemblages (see Barron, 1980a). At Site 555 the range of C. yabei is comparable to a temperate range; that is the range is similar to the range of $C$. yabei at North Pacific (Barron, 1980a) Site 173. The last occurrence of C. yabei at these sites approximates the last occurrence of $D$. praedimorpha and is older than the last occurrence of C. yabei reported from the tropics by Burckle (1972). Within the tropical region, the last occurrence of $C$. yabei approximates the first occurrences of Nitzschia fossilis, $N$. cylindrica and $N$. reinholdii (Barron, written comm.). Schrader (1977) and Barron (1980a) report that the last occurrence of $C$. plicatus is contemporary with the last occurrence of $C$. yabei within tropical regions.

At Site 555 the last occurrence of $C$. plicatus supports this stratigraphic range since its last occurrence approximates the first occurrence of the younger Nitzschia group. Therefore, in this study the last occurrence of $C$. plicatus is used as the primary datum in defining the top of the Coscinodiscus yabei Zone. The top of this zone is not represented at Site 408 as a result of dissolution. At Sites 552, 553, and 554, dissolution also inhibits the recognition of this zone. However, at Site 554 several cores contain sparse diatoms that are tentatively placed within the Coscinodiscus yabei Zone based on the co-occurrence of the primitive Nitzschia group ( $N$. praefossilis- $N$. praereinholdii) and Thalassiosira eccentrica without the Denticulopsis group. C. plicatus is presumed to be preservationally excluded.

Other floral elements: Actinocyclus ellipticus, C. radiatus, Hemidiscus cuneiformis, Melosira sulcata, and Rhizosolenia barboi.

Correlation: The top of this zone correlates with the lower portion of the $D$. petterssonii radiolarian zone as used by Westberg-Smith and Riedel (this volume). The Coscinodiscus yabei Zone overlaps with Subzone "a" of the Denticulopsis hustedtii Zone and the upper part of Subzone "d" of the Denticulopsis hustedtii-Denticulopsis lauta Zones of Barron (1980a).

\section{Nitzschia porteri-Nitzschia miocenica Interval}

Author: Burckle (1972, 1977).

Definition: The base of this interval is defined by the last occurrence of Coscinodiscus yabei. The top of this interval is defined by the first occurrence of Thalassiosira convexa and T. miocenica.

Remarks: Burckle $(1972,1977)$ defined the Nitzschia porteri and the Nitzschia miocenica Zones based on the last occurrence of $C$. yabei and the first occurrences of $N$. miocenica and $T$. convexa (see Fig. 3). Other useful datums defined within these zones include the last occurrence of $N$. porteri and the first occurrence of $T$. praeconvexa. Within the Rockall Region $N$. porteri is preservationally or ecologically excluded and $N$. mioceni$c a$ is extremely rare. This prevents the recognition of the first occurrence of $N$. miocenica, which defines the boundary between the Nitzschia porteri and Nitzschia miocenica Zones and dictates that these zones be combined. The Nitzschia porteri-Nitzschia miocenica Inter$\mathrm{val}$ is distinguished by the presence of $N$. fossilis, $N$. cylindrica, T. eccentrica, and T. nativa. The first occurrence of $T$. praeconvexa occurs within the upper part of this zone. 
Other floral elements: $C$. tabularis, Hemidiscus $\mathrm{cu}$ neiformis, Melosira sulcata, $N$. reinholdii, and Rhizosolenia barboi.

Correlation: The top of this interval correlates with the top of the calcareous nannofossil Zone NN11 as used by Backman (this volume) and to the lowermost portion of the Stichocorys peregrina radiolarian Zone as used by Westberg-Smith and Riedel (this volume). The Nitzschia porteri-Nitzschia miocenica Interval correlates with Subzone " $a$ " of the Denticulopsis kamtschatica and the upper portion of Subzone "b" of the Denticulopsis hustedtii Zone of Barron (1980a).

\section{Thalassiosira convexa Zone}

Author: Burckle (1972).

Definition: The base of this zone is defined by the first occurrence of $T$. convexa. The top of this zone is defined by the first occurrence of Nitzschia jouseae.

Remarks: Three subzones are recognized by Burckle (1972). The top of Subzone "A" (the oldest) is placed at the last occurrence of $T$. praeconvexa. The top of Subzone " $\mathrm{B}$ " is defined by the last occurrence of $T$. miocen$i c a$, and the top of Subzone " $\mathrm{C}$ " is equivalent to the top of the zone. Other useful datums within this zone include the last occurrence of Thalassiosira sp. 1 and the first occurrence of $T$. oestrupii. The first occurrence of $T$. miocenica is a secondary datum for the base of this zone. The base of this zone approximates the top of a dissolution interval that is present at all sites.

Other floral elements: Coscinodiscus nodulifer, C. tabularis, Hemidiscus cuneiformis, N. cylindrica, N. fossilis, $N$. reinholdii, and $N$. marina.

Correlation: The top of this zone tentatively correlates with the calcareous nannofossil Zones NN13/NN14 as used by Backman (this volume). The Thalassiosira convexa Zone correlates with Subzones " $a$ " and " $b$ " of the Denticulopsis kamtschatica Zone of Barron (1980a).

\section{Nitzschia jouseae Zone} ter).

Author: Base, Burckle (1972); top, Baldauf (this chap-

Definition: The base of this zone is defined by the first occurrence of $N$. jouseae. The top of this zone is defined by the last occurrence of $N$. jouseae.

Remarks: The top of the Nitzschia jouseae Zone as defined by Burckle (1972) is based on the first occurrence of Rhizosolenia praebergonii, which in the eastern Pacific is restricted to the equatorial region (see Burckle, 1972; 1978a). Within the western Pacific, Koizumi (1968) and Burckle (1972) record $R$. praebergonii in upper Tertiary sediments off Japan. Locally, within the Rockall Region, the occurrence of $R$. praebergonii is extremely rare and is not useful as a zonal marker. Therefore the top of the Nitzschia jouseae Zone (Burckle, 1972) is extended and here defined by the last occurrence of $N$. jouseae. The last occurrence of $N$. cylindrica occurs directly above the base of this zone.

Other floral elements: Coscinodiscus nodulifer, C. tabularis, Hemidiscus cuneiformis, Melosira sulcata, $N$. fossilis, N. marina, N. reinholdii, Synedra ulna, Thalassiosira oestrupii, and $T$. convexa.
Correlation: This zone correlates to the Nitzschia jouseae Zone and Subzone " $\mathrm{A}$ " of the Rhizosolenia praebergonii Zone of Burckle (1972). The Nitzschia jouseae Zone also in part correlates to NPDZ VIII and IX of Schrader (1973).

\section{Nitzschia marina Zone}

Author: Baldauf (this chapter).

Definition: The base of this zone is defined by the last occurrence of $N$. jouseae. The top of the zone is defined by the first occurrence of Pseudoeunotia doliolus.

Remarks: This zone is recognized by the occurrence of $N$. marina, $N$. fossilis, $N$. reinholdii, Hemidiscus cuneiformis, and Thalassiosira oestrupii. The last occurrence of $T$. convexa occurs within this zone.

Other floral elements: Coscinodiscus nodulifer, C. tabularis, Ethmodiscus rex, Melosira sulcata, Rhizosolenia barboi, $R$. hebatata, and Stephanopyxis turris.

Correlation: This zone correlates to Subzones "B" and " $\mathrm{C}$ " of the Rhizosolenia praebergonii Zone of Burckle (1972), and in part to NPDZ V and VIII of Schrader (1973).

\section{Pseudoeunotia doliolus Zone}

Author: Burckle (1972).

Definition: The base of this zone is defined by the first occurrence of $P$. doliolus. The top ranges to the present day.

Remarks: Burckle (1972) defined two subzones based on the last occurrence of Rhizosolenia praerbergonii. However, since $R$. praebergonii is so rare in Leg $81 \mathrm{ma}-$ terial, no subzones are recognized. $R$. curvirostris occurs within the upper portion of this zone at both Hole 552A and Site 554.

Other floral elements: Coscinodiscus nodulifer, Nitzschia fossilis, $N$. marina, $N$. pandurformis, $R$. bergonii, and Thalassiosira oestrupii.

Correlation: The base of this zone approximates the calcareous nannofossil boundary NN18/NN19 as used by Backman (this volume). The Pseudoeunotia doliolus Zone correlates to the Rhizosolenia curviostris, Actinocyclus oculatus, and Denticulopsis seminae Zones of Barron (1980a).

\section{EPOCH BOUNDARIES}

Ryan et al. (1974) and Hailwood et al. (1979) place the middle Miocene/late Miocene boundary within the calcareous nannofossil Discoaster hamatus Zone (NN9) of Martini (1971) and correlate this epoch boundary with the lowest normal event of paleomagnetic Epoch 11. The middle Miocene/late Miocene boundary approximates the boundary between the Rhizosolenia barboi and the Denticulopsis praedimorpha zones as defined in this chapter.

The Miocene/Pliocene boundary is placed within the upper portion of the calcareous nannofossil Zone NN12 of Martini (1971) and is correlated to the middle of the lowest magnetically reversed interval of the Gilbert paleomagnetic Epoch by Ryan et al. (1974), Cita (1975), and Van Couvering et al. (1976). Burckle and Opdyke (1977) place the Miocene/Pliocene boundary at a level higher 
than the top of paleomagnetic Epoch 5 but lower than the "c" event of the Gilbert Epoch. This placement agrees with the previously mentioned workers and is based on analysis of the diatom flora from the "Tripoli" in the lower portion of the neostratotype Messinian Stage. The Miocene/Pliocene boundary falls in the upper portion of the Thalassiosira convexa Zone as used in this chapter and is approximated by the last occurrence of $T$. miocenica (Burckle, 1978b).

Burckle and Opdyke (1977) and Haq et al. (1977) place the Pliocene/Pleistocene boundary at the top of the Olduvai Event of the Matuyama paleomagnetic Epoch. Although others suggest that this placement should be slightly lower (see Ryan et al., 1974), the author adheres to the conclusions of Haq et al. (1977) and correlates the Pliocene/Pleistocene boundary with the top of the Olduvai. The Pliocene/Pleistocene boundary correlates with the lower portion of the Pseudoeunotia doliolus Zone as used in this chapter.

The paleomagnetic scale of Hailwood et al. (1979) is used in this chapter for the time interval from 11.0 to $65.0 \mathrm{~m} . \mathrm{y}$. For the younger interval of time (0-11.0 m.y.) the paleomagnetic scale of Ness et al. (1980) is adopted.

\section{METHODS}

Approximately $1.5 \mathrm{~cm}^{3}$ of sample was placed into a 400 -ml beaker. The sample was disaggregated with the addition of $10 \mathrm{ml}$ of $30 \%$ hydrogen peroxide. Upon completion of the resulting reaction, $30 \mathrm{ml}$ of $37 \%$ hydrochloric acid was added. The sample was then gently heated until the liquid became light yellow in color. The sample's acidity was then neutralized by the addition of approximately $300 \mathrm{ml}$ of distilled water, and then the sample was decanted after $2 \mathrm{hr}$. of settling. This decanting process was continued until $\mathrm{pH} 7$ was reached. Strewn slides were prepared on $22 \times 40 \mathrm{~mm}$ cover glasses and mounted in Hyrax on $22 \times 75 \mathrm{~mm}$ glass slides.

Strewn slides of acid-cleaned material prepared aboard the Glomar Challenger were re-examined together with additional samples processed at onshore facilities. One cover glass was examined in its entirety at $\times 500$ with use of an Olympus $\mathrm{BH}-2^{3}$ light microscope. Species identifications were confirmed at $\times 1250$. Species were recorded as abundant if two or more specimens were present within one field of view at $\times 500$; common if one specimen occurred in two fields of view; few if one specimen was observed per horizontal traverse; and rare if specimens were encountered less frequently. Quality of fossil preservation of samples is based on the ratio of finely silicified taxa to robust and heavily silicified forms in each sample.

Samples within the uppermost $55 \mathrm{~m}$ of Hole $552 \mathrm{~A}$ were examined for the fluctuation in diatom abundance, which is based on the average number of diatom frustules observed per field of view. A numeri$\mathrm{cal}$ value was obtained for each sample by dividing the total number of diatoms observed by the field of view encountered. At least 450 fields of view $(0.5 \mathrm{~mm})$ at a magnification of $\times 500$ were observed for each sample. The resulting numerical value for each sample was then placed into one of the following categories: Samples that are barren of diatoms, samples that average one diatom specimen observed per eight fields of view, samples in which at least one specimen was observed in four fields of view, samples in which at least one specimen was observed in two fields of view, samples that contain at least one diatom per field of view, and those samples in which two or more diatoms were observed for each field of view. The counting techniques of Schrader and Gersonde (1978) were employed during this study.

\footnotetext{
${ }^{3}$ Any use of trade names is for descriptive purposes and does not imply endorsement by the U.S. Geological Survey (USGS).
}

\section{BIOSTRATIGRAPHY}

\section{Site 552}

Site 552, located adjacent to DSDP Site 404 on the western margin of the Rockall Plateau, was drilled in hope of determining the chronology of the dipping reflector sequence present beneath the sediment cover. A secondary objective for Site $\mathbf{5 5 2}$ was to document the climatological and oceanographic changes within this region throughout the Tertiary Period.

Diatoms vary in abundance from rare to common in the Eocene to Quaternary sediments recovered from Site 552. Preservation is generally poor in the Eocene sediments, which have a flora dominated by Stephanopyxis grunowii, Melosira clavigeria, and Arachnoidiscus sp. Sponge spicules are common to abundant within the middle and uppermost Eocene sediments. Diatom preservation is usually moderate in the Neogene sediments. However, occasional intervals do occur where well-preserved and abundant diatoms are present.

Table 1 illustrates the zonal assignments of the cores recovered from Site 552 and other sites from Leg 81 . It should be noted that a depth discrepancy of approximately $10 \mathrm{~m}$ exists between the depth of a prominent marker horizon observed in cores from both Holes 552 and 552A. Although the cause of this discrepancy is uncertain, the probable cause may be a miscount in the drill barrel length during the washing operation at Hole 552 .

\section{Hole 552}

Twenty-five cores $(79.19 \mathrm{~m})$ were recovered from Hole $552\left(56^{\circ} 02.56^{\prime} \mathrm{N}, 23^{\circ} 13.88^{\prime} \mathrm{W}, 2311 \mathrm{~m}\right.$ water depth) by rotary drilling. A dissolution interval occurs in Cores $552-1$ and 552-2. This interval is approximately $10 \mathrm{~m}$ stratigraphically higher in Hole 552 than in Hole 552A. Ice-rafted detritus is common throughout this interval. Sample 552-2,CC is Pliocene in age based on the occurrence of Thalassiosira convexa var. aspinosa, and $T$. oestrupii. The base of the Thalassiosira convexa Zone in Section 2 of Core 4 coincides with a dissolution interval that is recognized at all sites (see Fig. 10). In Hole 552 this dissolution interval occurs from Section 2 of Core 4 through Core 9. All samples examined within this interval, with the exception of Sample 552-6-3, 106-107 cm, either contain rare to few poorly preserved diatoms or are barren. Sample 552-6-3, 106-107 cm contains few moderately preserved diatoms and is tentatively placed in the Nitzschia porteri-Nitzschia miocenica Interval. This age assignment is based on the presence of $N$. reinholdii, $N$. marina, and $T$. eccentrica. The absence of T. convexa and Coscinodiscus yabei support this assignment.

One specimen of Triceratium castelliferum was observed in Sample 552-8,CC. This species is reported from the middle Eocene of the South Atlantic (DSDP Site 356; Fenner, 1977) and the late Eocene of Oamaru, New Zealand (Schmidt et al., 1874). The occurrence of this Eocene species suggests that a hiatus exists between the 
Table 1. Diatom zonation of samples from DSDP Leg 81 sites.

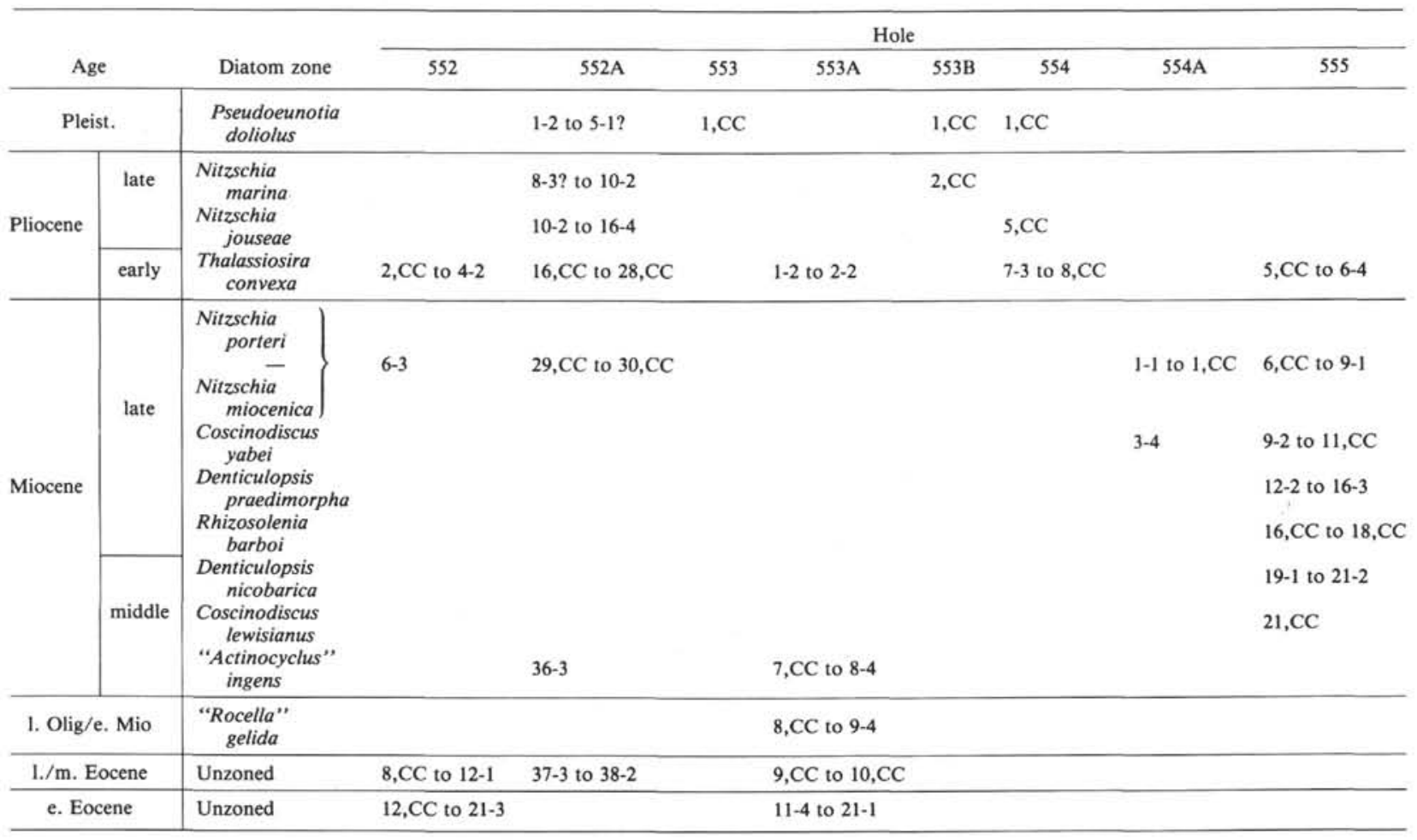

middle Miocene (Sample 552-6-3, 106-107 cm) and the Eocene $(552-8, \mathrm{CC})$. This is in agreement with the nannofossil stratigraphy of Backman (this volume), in which a hiatus of approximately 25 m.y. occurs in Section 4 of Core 8 and separates the middle Miocene from the middle Eocene.

Few moderately preserved Eocene diatoms are present in Sample 552-10,CC. The presence of $T$. castelliferum and Stephenopyxis grunowii suggests a middle to late Eocene age. The absence of Pyxilla reticulata, Trinacria pileolus, T. simulacrum, and T. excavata var. tetragona, which are common within sediments assigned by nannofossil control to the early Eocene (see Hole 553A), supports this age call. The common occurrence of several species of Arachnoidiscus within this sample suggests a shelf environment.

Except for Cores 12, 14, and 21 (Core 11 had no recovery) all other samples examined contain poorly preserved specimens or are barren of diatoms. Cores 12, 14, and 21 are early Eocene in age based on the occurrence of $P$. reticulata, $T$. pileolus, $T$. excavata var. tetragona, and Rhizosolenia interposita. Numerous varieties of Stephanopyxis are common in Sample 552-14-2, 125$126 \mathrm{~cm}$.

\section{Hole 552A}

Hole $552 \mathrm{~A}\left(56^{\circ} 02.56^{\prime} \mathrm{N}, 23^{\circ} 13.88^{\prime} \mathrm{W}, 2311 \mathrm{~m}\right.$ water depth) was hydraulic piston cored (HPC) from 0 to $183.5 \mathrm{~m}$ sub-bottom. Eocene and middle Miocene to Holocene diatoms are present throughout the $183.5 \mathrm{~m}$ of sediment recovered. Table 2 shows the stratigraphic occurrence of selected diatoms. Figure 5 shows the ranges of selected stratigraphically useful species. Reworking of Eocene, early Miocene, and middle Miocene species occurs sporadically throughout the hole.

Cores 1 and 2 are assigned to the Pseudoeunotia doliolus Zone and contain a well-preserved diatom assemblage that includes such species as $P$. doliolus, Rhizosolenia bergonii, Hemidiscus cuneiformis, Thalassiosira oestrupii, and Nitzschia panduriformis. The presence of Rhizosolenia curvirostris in Sample 552A-2-2, $52 \mathrm{~cm}$ through Sample 552A-2-3, $1 \mathrm{~cm}$ suggests that these samples have an age between 0.35 and approximately $1.5 \mathrm{~m} . \mathrm{y}$.

The placement of the base of the Pseudoeunotia doliolus Zone, defined by the first occurrence of $P$. doliolus, is difficult to determine because an interval of dissolution exists between Samples 552A-2-3, $30 \mathrm{~cm}$ and $552 \mathrm{~A}-7-3,119 \mathrm{~cm}$. Samples within this interval are generally barren of diatoms. However, Sample 552A-5-1, $90 \mathrm{~cm}$ contains common well-preserved diatoms. The presence of $P$. doliolus in this sample places the base of the Pseudoeunotia doliolus Zone between this sample and Sample 552A-8-3, 91-92 cm, which is directly below the dissolution interval.

The presence of $N$. reinholdii, $N$. fossilis, and the silicoflagellate Mesocena quadrangula in Sample 552A-5-1, $90 \mathrm{~cm}$, suggests that this sample is older than 0.79 m.y. ago, the age cited by Burckle (1977) for the last occurrence of $M$. quadrangula in the central Pacific.

The presence of $N$. fossilis, which has a last occurrence that approximates the last occurrence of $M$. quadrangula (see Barron, 1980a), supports this age for Sample 552A-5-1, $90 \mathrm{~cm}$. Within the central Pacific, Koizumi and Kanaya (1976) place the last occurrence of $N$. fossilis between the Jaramillo Event of the Matuyama Epoch and the earliest part of the Brunhes Epoch. 
Table 2. Stratigraphic occurrence of selected diatoms in Hole 552A.






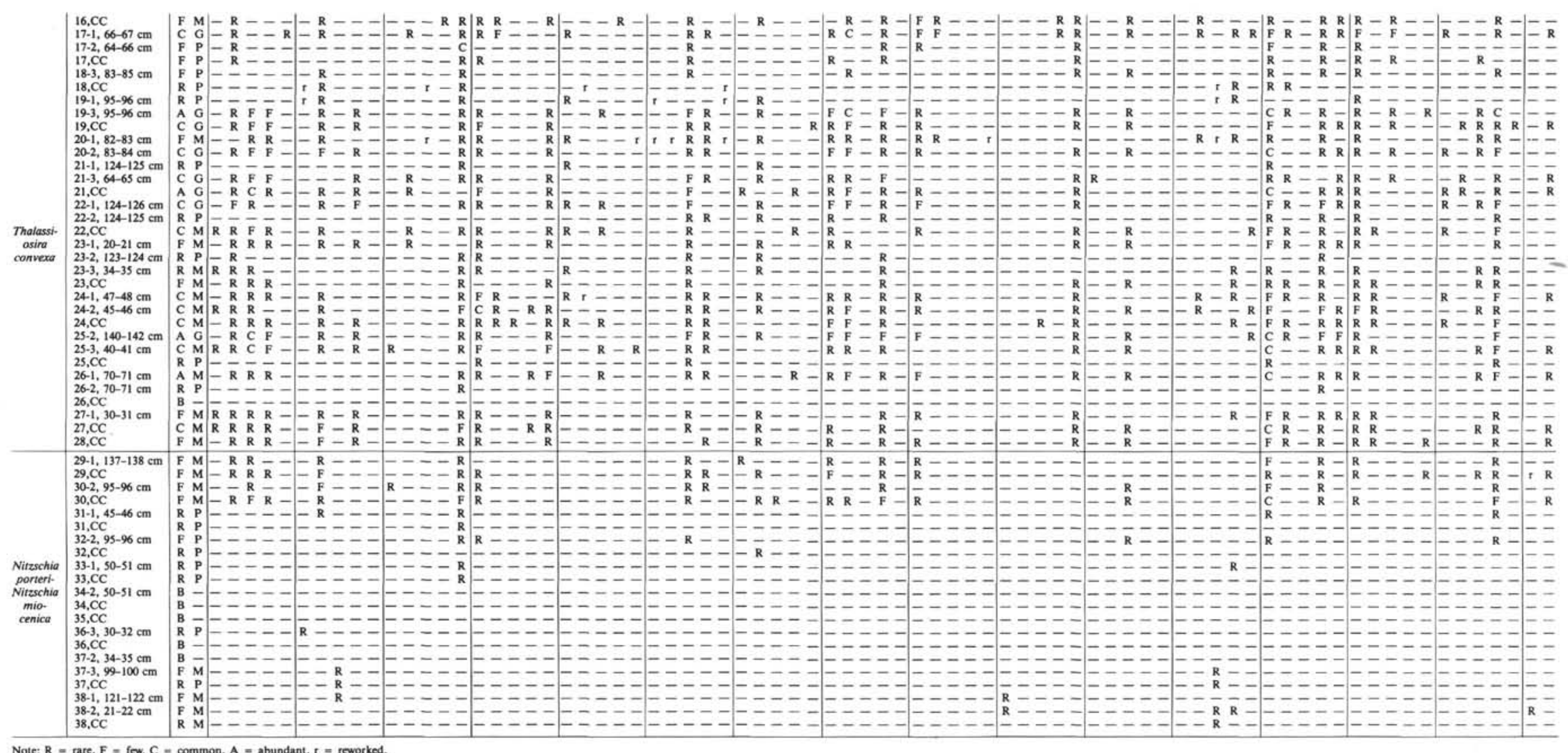

Note: $\mathbf{R}=$ rare, $\mathbf{F}=$ fow, $\mathrm{C}=$ common, $\mathbf{A}=$ abundant, $r=$ reworked 


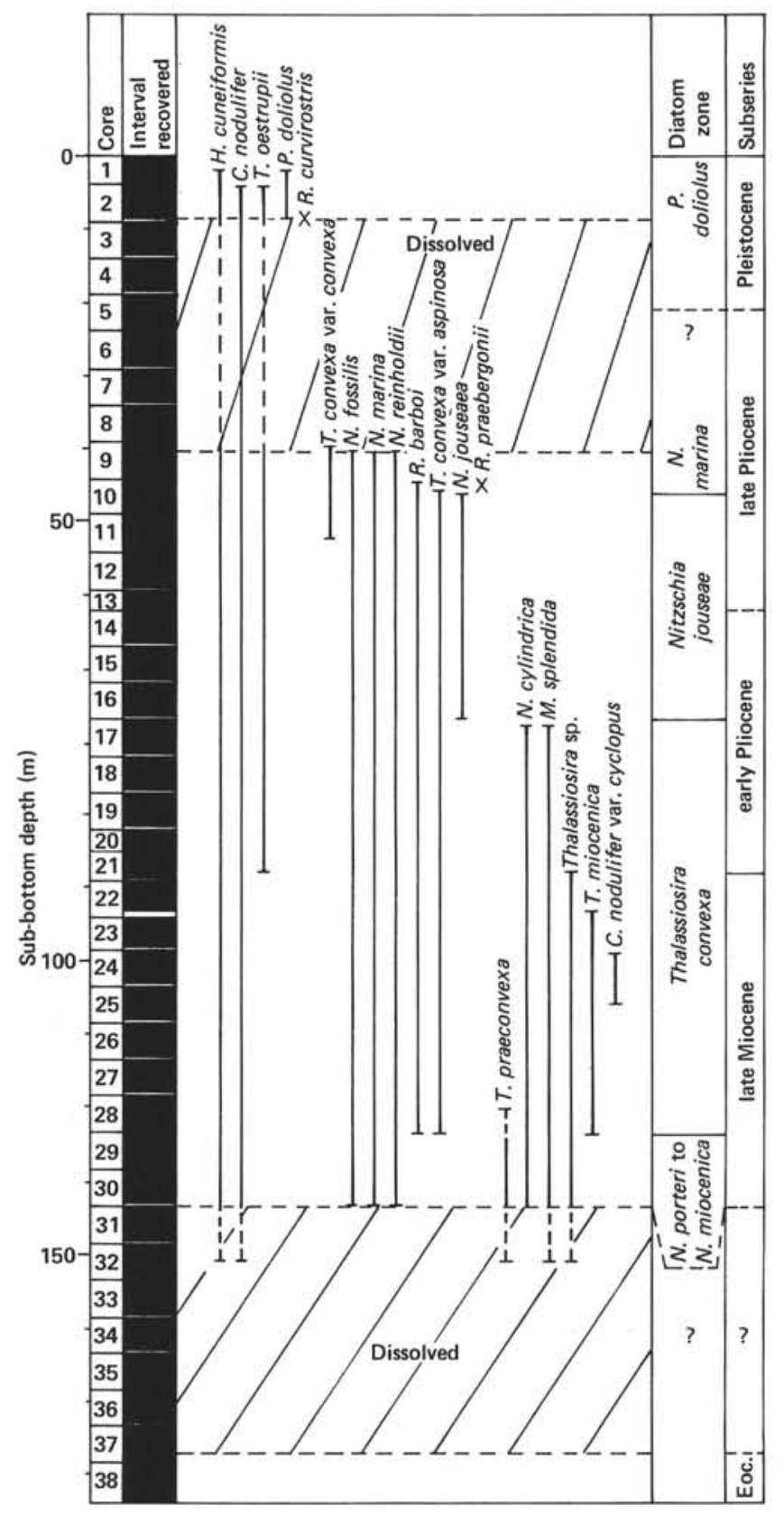

Figure 5. Stratigraphic ranges of selected diatoms at Hole 552A.

The paleomagnetic results of Leg 81 (see Zimmerman et al., this volume) place the base of the Jaramillo Event between Samples 552A-5-1, $85 \mathrm{~cm}$ and 552A-5-1, $112 \mathrm{~cm}$. The Matuyama Brunhes Epoch boundary is placed in Section 1 of Core 4. These data suggest that the presence of $N$. fossilis in Sample $552 \mathrm{~A}-5-1,90 \mathrm{~cm}$ is slightly below the species' last occurrence and that the true last occurrence of $N$. fossilis is not observed because of dissolution.

Other species present in Sample 552A-5-1, $90 \mathrm{~cm}$ include Denticulopsis seminae, D. seminae var. fossilis, and Roperia tesselata. These species are indicative of both higher latitudes $(D$. seminae and $D$. seminae var. fossilis) and lower latitudes ( $R$. tesselata) and may repre- sent the influx of colder polar waters into the temperate waters of the Rockall Region.

The Nitzschia marina Zone is partially represented by a dissolution interval that is dominated by ice-rafted detritus. This interval extends from Sample $552 \mathrm{~A}-2-3,30 \mathrm{~cm}$ through Sample 552A-7-3, $119 \mathrm{~cm}$ and can be correlated to a similar interval present at Hole 552 .

Although the last common occurrence of $T$. convexa occurs at Sample 552A-10-2, 0-3 cm, the true last occurrence of this species is at Sample 552A-9-1, $63 \mathrm{~cm}$. The paleomagnetic results of Leg 81 place this event a third of the way between the Gauss/Matuyama boundary and the Olduvai paleomagnetic Event. The placement of this datum agrees exactly with the results of Burckle and Trainer (1979).

The last occurrence of $N$. jouseae, which defines the base of the Nitzschia marina Zone, occurs between Sample $552 \mathrm{~A}-10-2,30 \mathrm{~cm}$, and $10-2,20 \mathrm{~cm}$. The paleomagnetic results of Leg 81 place these samples approximately midway between the top of the Kaena Event and the Gauss/Matuyama boundary. The age of this datum event therefore agrees well with an age of $2.6 \mathrm{~m}$.y. ago, assigned by Burckle and Trainer (1979) for this event within the central Pacific (see Fig. 6).

The only specimen observed of $R$. praebergonii appears in Sample 552A-10-1, 70-73 cm. The presence of this warm-water species, which is confined typically to the tropics (see Burckle, 1972, 1978b), within the Rockall Region reflects the influence of the North Atlantic Drift within this region.

Koizumi (1968) records $R$. praebergonii in sediments examined from the Oga Peninsula of Japan. Barron (1980a) similarly records this species off the northeast coast of Japan. The presence of this species at high latitude is the result of its having been transported by the warm-water, northward-flowing Kuroshio Current, a situation similar to the North Atlantic Drift influence within the Rockall Region. $R$. praebergonii is also recorded by Schrader (1977) from DSDP Sites 332 and 333 within the central Atlantic.

The Nitzschia jouseae Zone is represented in the interval from Samples 552A-10-2, $30 \mathrm{~cm}$ to 552A-16-4, $7-8 \mathrm{~cm}$. The base of this zone is defined by the first occurrence of $N$. jouseae.

Burckle $(1972,1978 b)$ correlates the first occurrence of $N$. jouseae with the "C" Event of the Gilbert Epoch. Therefore this datum approximates $4.5 \mathrm{~m}$.y. ago. Using this date for the first occurrence of $N$. jouseae in the North Atlantic results in a somewhat uniform sediment accumulation rate (see Fig. 7) which suggests that this datum event at Site 552 is isochronous with the equatorial Pacific.

However, the placement of the first occurrence of $N$. jouseae between Sample 552A-16-4, 7-8 cm and 552A$16, \mathrm{CC}$ is in slight disagreement with the nannofossil results. Backman (this volume) places the calcareous nannofossil NN13/NN14 Zonal Boundary (which approximates 4.3 m.y. ago) between Samples 552A-16,CC and 552A-18,CC based on the occurrence of Amaurolithus primus and Discoaster asymmetricus in Sample 552A$16, \mathrm{CC}$ (Zone NN14) and Ceratolithus rugosus in Sam- 


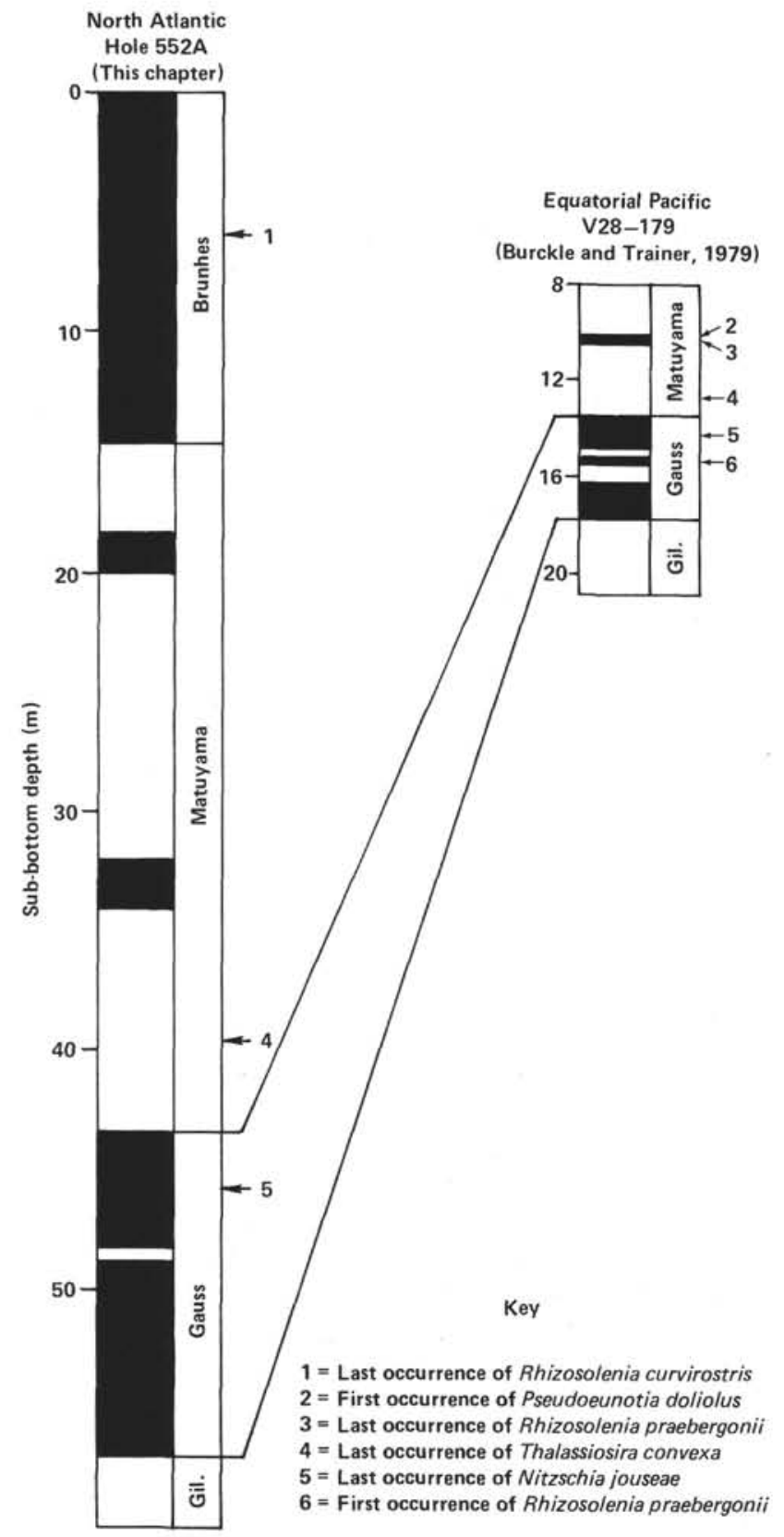

Figure 6. Comparison of the correlation between diatom datums and paleomagnetic results of Hole $552 \mathrm{~A}$ with the correlations completed by Burckle and Trainer (1979) between diatom datums and paleomagnetic stratigraphy from the equatorial Pacific.

ple 552A-18,CC (Zone NN13). The occurrence of $C$. rugosus in Sample 552A-18,CC suggests that the stratigraphic first occurrence of $N$. jouseae should be slightly lower.

The last occurrence of $N$. cylindrica occurs between Sample 552A-17-1, 66-67 cm and 552A-16,CC. Burckle (1978b) places this datum above the "C" Event of the Gilbert Epoch. The first occurrence of $N$. jouseae is placed within the upper portion of the " $C$ " Event of the Gilbert Epoch. If the placement of the last occurrence of $N$. cylindrica is correct, then the last occurrence of $N$. jouseae should be stratigraphically lower. This would also suggest that this datum is not isochronous, although

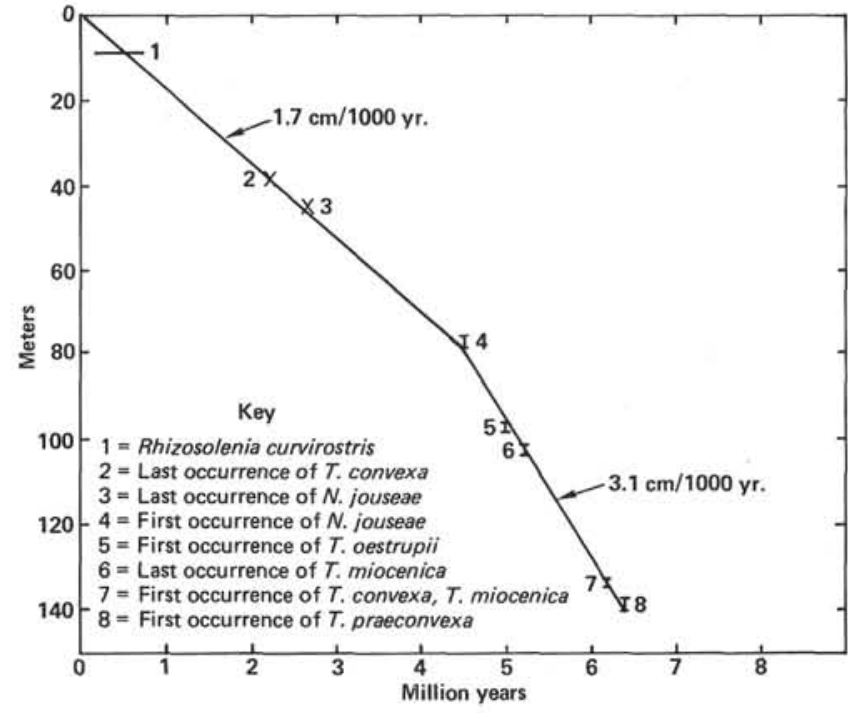

Figure 7. Sediment accumulation rate curve calculated for Hole 552A from diatom datum levels.

this would agree better with the nannofossil data. The reliability of $N$. cylindrica is questionable (see Burckle, $1978 \mathrm{~b}$ ), whereas the isochroneity of the first occurrence of $N$. jouseae between the North Pacific and the Atlantic, as warranted by the sedimentation curve, suggests that the latter datum is more consistent and reliable. Burckle (1978b) suggests that the last appearance of $N$. cylindrica in high latitudes may be diachronous. Furthermore, a rank and reliability factor of third order was assigned to this datum based on the difficulty in identification and the numerous local ecological or geographical restrictions. Contrary to this, the first occurrence of $N$. jouseae is assigned a first-order ranking (Burckle, 1978b) based on the ease of identification and "common and persistent either first rapid evolutionary appearance or highly consistent range." This suggests that this occurrence of $N$. jouseae is the true first occurrence. However, further quantitative studies are required to resolve the disagreement between diatoms and nannofossils.

The base of the Thalassiosira convexa Zone is defined by the first occurrence of $T$. convexa. A secondary marker that is nearly synchronous with the $T$. convexa event is the first occurrence of $T$. miocenica. Both species first appear in Sample 552A-28,CC. The first occurrence of T. oestrupii is in Sample 552A-21-3, 64-64 cm. This datum is placed by Burckle and Opdyke (1977) within the lowest portion of the Gilbert Epoch and is suggested by Barron (1980a) to approximate the Miocene/Pliocene Boundary of Van Couvering et al. (1976).

The last occurrence of $T$. miocenica that also approximates the Miocene/Pliocene boundary is in Sample 552A-22,CC. Burckle (1978b) correlates this event to midway between the " $C$ " Event of the Gilbert Epoch and the top of Epoch 5. T. praeconvexa, which has a very short stratigraphic range, is correlated by Burckle (1978b) to occur from the middle of Epoch 6 to the middle of the lowest normal event of Epoch 5. Within DSDP Hole 552A, $T$. praeconvexa occur from Samples 552A-32-2, 
95-96 cm to Sample 552A-28,CC. The range of this species slightly overlaps the basal boundary of the Thalassiosira convexa Zone and is a useful secondary marker.

The Nitzschia porteri-Nitzschia miocenica Interval is recognized from Sample 552A-32-2, 95-96 cm to Sample 552A-28,CC based on the occurrence of $T$. praeconvexa below the first occurrence of $T$. miocenica and $T$. convexa. $N$. aff. miocenica is also observed within this interval.

The abrupt downcore change in diatom preservation observed at all sites (see Fig. 10) at approximately 6.2 m.y. ago occurs within the uppermost portion of Core 31 . The presence of Actinocyclus ingens in Sample 552A$36-3,30-32 \mathrm{~cm}$ suggests that this sample is middle Miocene in age. Section 3 of Core 37 through Core 38 is Eocene in age and contains an assemblage similar to that found in Cores 552-10 and 552-12. Sponge spicules are common within this interval.

\section{Site $\mathbf{5 5 3}$}

Three holes were rotary cored at Site 553, located northwest of Site 552 on the Hatton Drift, which extends along the western margin of the Rockall Plateau. Preservation of diatoms in the Eocene to Recent sediments recovered is similar to that at Site 552. Preservation is generally moderate, however, two dissolution intervals occur: one is Pliocene-Pleistocene and the other is late Miocene in age. The Pliocene-Pleistocene interval is dominated by ice-rafted detritus. Both dissolution intervals are equivalent in age to similar intervals recognized at Site 552.

A single mudline core taken at Hole 553 contains well-preserved Pleistocene diatoms which are assigned to the Pseudoeunotia doliolus Zone based on the presence of $P$. doliolus.

\section{Hole 553A}

Fifty-nine cores $(531.5 \mathrm{~m})$ were recovered from Hole $553 \mathrm{~A}\left(56^{\circ} 05.32^{\prime} \mathrm{N}, 23^{\circ} 20^{\prime} \mathrm{W}, 2335 \mathrm{~m}\right.$ water depth). A reentry cone set with casing was placed at a subsurface depth of $56.5 \mathrm{~m}$, resulting in a late Miocene-early Pliocene age for both Cores 1 and 2. These cores are assigned to the Thalassiosira convexa Zone. The Miocene/ Pliocene boundary approximates the first occurrence of T. oestrupii in Sample 553A-1,CC.

The interval of dissolution present at the base of the Thalassiosira convexa Zone throughout the Leg 81 sites occurs from Core 2 through Section 3 of Core 7. Actinocyclus ingens and Denticulopsis hyalina are both observed in Sample 553A-7,CC and occur stratigraphically down to Sample 553A-8-3, $103 \mathrm{~cm}$, indicating a middle Miocene age for the interval from Sample 553A-7,CC to Sample 553A-8-3, $103 \mathrm{~cm}$. A hiatus occurs directly below this interval. Diatoms are very rare from Section 4 of Core 8 through Section 3 of Core 9. However, this interval is earliest Miocene in age based on the rare occurrence of Rocella gelida. The frequence of $R$. gelida increases downcore, becoming common in Section 3 of Core 9. Weaver and Gombos (1981) place the Oligocene/Miocene boundary within the range of Bogorovia veniamini just above the acme of $R$. gemma (this species is a synonym for $R$. gelida). Similarly Gombos and Ciesielski (1983) place this boundary above the acme of $R$. gelida.

This would suggest that the Oligocene/Miocene boundary change of La Brecque et al. (1977) can be approximately placed in Section 3 of Core $9(94-95 \mathrm{~cm})$. However, diatoms are rare within the interval and no secondary markers are available. Nannofossil control (Backman, this volume) records the extinction of Dictyococcites bisectus, which approximates the Oligocene/Miocene boundary of Hailwood et al. (1979) between Samples $553 \mathrm{~A}-9-4,5 \mathrm{~cm}$ and 553A-9-4, $15 \mathrm{~cm}$, therefore suggesting a slightly lower stratigraphic placement of this boundary.

A third hiatus is recognized between Samples 553A-9-4, $67-68 \mathrm{~cm}$ (late Oligocene) and Sample 553A-9,CC, which is assigned to the Eocene. An Eocene age is also assigned to samples examined in Cores 10 and 11 . The presence of Coscinodiscus oblongus, Brightwellia coronata, and rare Trinacria species in Core 10 suggests a middle to late Eocene age. The presence of common Trinacria [T. pileolus, T. excavata, T. simulacrum, and T. excavata var. tetragona], Peterotheca aculifera, Stictodiscus angulatus, Pyxilla renticulata, Rhizosolenia interposita, and Sceptroneis gemmata in Core 11 suggests a late Paleocene to early Eocene age. Locally these species are common throughout the interval assigned by nannofossil control (Backman, this volume) to the early Eocene.

All samples examined below Core 11 are barren of diatoms, with the exception of Samples 553A-18,CC, 533A-21,CC, 553A-22, CC, 553A-23,CC, 533A-24,CC, and 553A-37-2, $28 \mathrm{~cm}$. Samples 553A-18,CC, 553A$21, \mathrm{CC}, 553 \mathrm{~A}-22, \mathrm{CC}$, and 553A-23, CC contain nondiagnostic diatom frustules in which silica is replaced by calcite. Samples 553A-24,CC and 553A-37-2, $28 \mathrm{~cm}$ contain pyritized diatom frustules of Triceratium sp. and Coscinodiscus sp.

\section{Hole 553B}

Of the four cores recovered from Hole 553B $\left(56^{\circ}\right.$ $05.32^{\prime} \mathrm{N}, 23^{\circ} 20.61^{\prime} \mathrm{W}, 2399 \mathrm{~m}$ water depth) only Core 1 contains moderately preserved diatoms. This core is assigned to the Pseudoeunotia doliolus Zone. Cores 2 through 4 contain either nondiagnostic specimens or are barren of diatoms. Ice-rafted detritus is present throughout these cores. This interval correlates to a similar interval of dissolution present within the Nitzschia marina Zone at Site 552.

\section{Site 554}

Site 554 , located slightly northwest of Sites 552 and 553 , was rotary cored to examine the nature of the outer high which forms the western boundary of a suite of dipping reflectors (see Roberts, this volume). Diatoms are generally poor to moderately preserved within the sediments recovered.

\section{Hole 554}

Eight cores $(76 \mathrm{~m})$ of upper Miocene to Holocene sediments were recovered from Hole $554\left(56^{\circ} 17.41^{\prime} \mathrm{N}, 23^{\circ}\right.$ $31.69^{\prime} \mathrm{W}, 2584 \mathrm{~m}$ water depth). Diatoms are poor to 
moderately preserved. Samples examined from Core 1 are assigned to the Pleistocene Pseudoeunotia doliolus Zone based on the presence of $P$. doliolus. The occurrence of Rhizosolenia curvirostris in Sample 554-1,CC suggests that this sample has an age between 0.35 and $1.5 \mathrm{~m} . \mathrm{y}$.

The Pliocene-Pleistocene dissolution interval observed at both Sites 552 and 553 occurs within Cores 2-6 of Hole 554. With the exception of Sample 554-5,CC, all samples examined from this interval are either barren or contain rare nondiagnostic specimens. Sample $554-5, \mathrm{CC}$ is tentatively assigned to the Nitzschia jouseae Zone based on the very rare occurrence of $N$. jouseae. Other species present include Thalassiosira oestrupii, Nitzschia fossilis, $N$. reinholdii, Coscinodiscus nodulifer, and $R$. barboi.

Cores 7 and 8 are placed in the late Miocene portion of the Thalassiosira convexa Zone based on the presence of T. convexa, T. miocenica, and Thalassiosira sp. 1. The occurrence of $T$. praeconvexa in Sample 5548 ,CC suggests that this sample approximates the base of the Thalassiosira convexa Zone.

\section{Hole 554A}

Hole 554 was abandoned because of deteriorating weather conditions. After approximately a 5-hr. delay, weather conditions improved enough for drilling operations of Hole $554 \mathrm{~A}\left(56^{\circ} 17.4^{\prime} \mathrm{N}, 23^{\circ} 31.65^{\prime} \mathrm{W}, 2584 \mathrm{~m}\right.$ water depth) to commence. The top $76 \mathrm{~m}$ of sediment was washed down to reach the approximate level where drilling was stopped at Hole 554. Six cores $(137 \mathrm{~m})$ of lower Eocene to upper Miocene sediments were recovered. Diatom preservation throughout this hole is generally poor although several samples were observed that contain common moderately preserved diatoms.

Sample 554A-1-1, 15-17 cm is placed in the uppermost portion of the Nitzschia miocenica Zone of Burckle (1972). This age assignment is based on the presence of Thalassiosira praeconvexa below the first occurrence of $T$. convexa and T. miocenica within Sample 554$8, \mathrm{CC}$. Therefore the base of the Thalassiosira convexa Zone, defined by the first appearance of $T$. convexa, occurs between Sample 554-8, CC and 554A-1-1, 15-17 cm. Burckle and Trainer (1979) correlate the first occurrence of these datums with the upper portion of Epoch 6, which suggests that these samples have an age of approximately $6.2 \mathrm{~m}$.y. Nannofossil biostratigraphy places the NN11/NN12 boundary (approximately 6.0 m.y.) between Sample 554A-6-5, $46 \mathrm{~cm}$ and Sample 554A-6,CC. The calcareous nannofossil Zone NN11 extends from Sample 554-6,CC through Sample 554A-1,CC. This sample interval is assigned by Backman (this volume) to the Discoaster neorectus subzone of Bukry (1973) which correlates with the lowest portion of Zone NN11 (approximately 9.6-10.3 m.y.). Although this discrepancy between diatom and nannofossil biostratigraphy is present, further work is required to explain what factors are responsible. Radiolarian biostratigraphy (WestbergSmith and Riedel, this volume) for Samples 554-8,CC and 554A-1-1, 18-20 cm suggests that these samples are near the evolutionary transition between $S$. delmontensis and $S$. peregrina and therefore approximate the $S$.
perigerna-D. pentultima Zonal boundary (approximately 6.5 m.y.).

Sample 554A-1,CC contains few moderately preserved diatoms. However, no age diagnostic forms were observed. The presence of numerous varieties of the genus Nitzschia suggests that this sample is younger than 9.0 m.y.

Sample $554 \mathrm{~A}-3-4,90-92 \mathrm{~cm}$ is tentatively placed within the Coscinodiscus yabei Zone. This zonal assignment is based on the presence of Hemidiscus cuneiformis, which has a first occurrence at approximately 12.0 m.y. ago, and the absence of the numerous Nitzschia species, which have an approximate first occurrence at 9.0 m.y. ago. Supporting this zonal assignment is the presence of Thalassiosira sp. 1 of Barron (1980a). All other samples examined from Hole 554A contain no age-diagnostic specimens or are barren of diatoms.

\section{Site 555}

Site 555 is located northeast of Site 554 within the shallow water of Hatton Bank. This location was selected in an effort to complete the dipping reflector transect from oceanic to continental crust. Furthermore, plans were made to HPC the Pliocene-Pleistocene sediments within this region for paleoceanographic reconstruction. However, time restrictions permitted only the rotary coring of a single hole.

\section{Hole 555}

Ninety-eight cores $(505 \mathrm{~m})$ of upper Paleocene to Pleistocene sediments were recovered from Hole $555\left(56^{\circ}\right.$ $33.70^{\prime} \mathrm{N}, 20^{\circ} 46.93^{\prime} \mathrm{W}, 1669 \mathrm{~m}$ water depth). No siliceous upper Pliocene or Pleistocene sediments are present. Diatoms are generally rare to abundant throughout the upper 28 cores recovered. However, within this interval occasional samples are barren of diatoms. Generally samples examined stratigraphically below Core 22 are barren of siliceous material. Diatoms are especially common throughout several intervals within middle Miocene sediments. Table 3 shows the stratigraphic occurrence of selected diatom species. The ranges of selected stratigraphically important species are recorded in Figure 8.

Samples examined from Cores 555-1 through 555-4 are either barren or contain no age-diagnostic species. Species observed include Hemidiscus cuneiformis, Actinoptychus undulatus, Thalassiosira eccentrica, and Nitzschia reinholdii.

Common moderately preserved diatoms are observed in Core 555-5 through Section 555-6-4. This late Miocene interval is assigned to the Thalassiosira convexa Zone based on the presence of Thalassiosira convexa s. ampl., T. miocenica, and Thalassiosira sp. 1. The inter$\mathrm{val}$ of dissolution presence at the base of this zone at all other Leg 81 sites occurs from Core 555-6 through Section 555-8-4.

Sample 555-8,CC contains $N$. cylindrica, H. cuneiformis, N. marina-reinholdii, and Rhizosolenia barboi. This sample is assigned to the Nitzschia porteri-Nitzschia miocenica Interval.

The Coscinodiscus yabei Zone is assigned to the interval from Section 555-9-2 through Section 555-11-2 based on the occurrence of $C$. plicatus, Denticulopsis 
Table 3. Stratigraphic occurrence of selected diatoms in Hole 555.

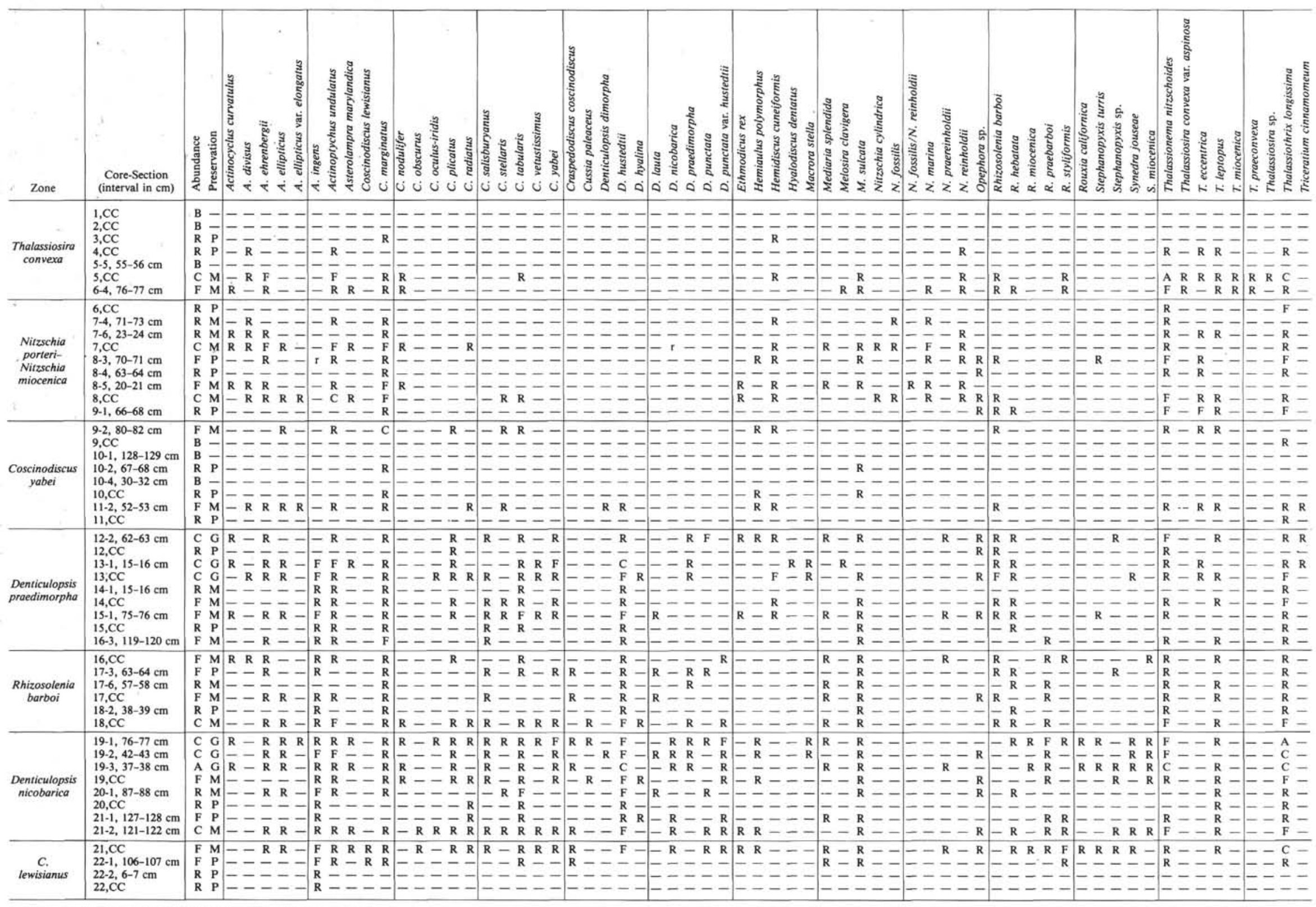

Note: $\mathbf{R}=$ rare, $\mathbf{F}=$ few, $\mathrm{C}=$ common, $\mathrm{A}=$ abundant, $\mathrm{r}=$ reworked 


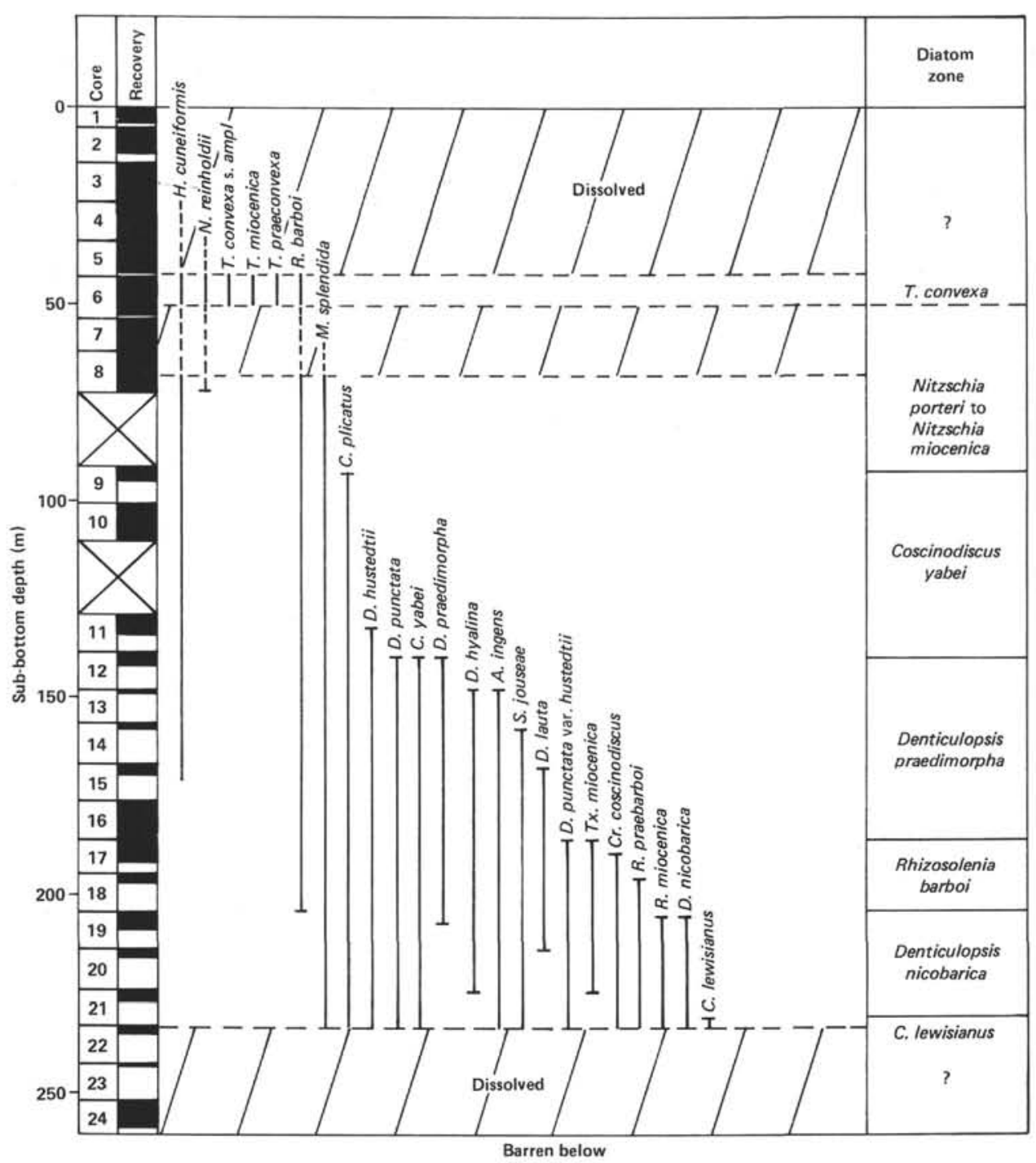

Figure 8. Stratigraphic ranges of selected diatoms from Hole 555.

hustedtii, and $H$. cuneiformis. Preservation within this interval is poor to moderate.

Few to common, moderately to well-preserved diatoms occur in Cores 12 through 16. Species present within this interval include $D$. hustedtii, $D$. punctata, $D$. praedimorpha, D. hyalina, C. yabei, C. plicatus, Actinocyclus ingens, and $H$. cuneiformis. This late middle Miocene assemblage is assigned to the Denticulopsis praedimorpha Zone.

The Rhizosolenia barboi Zone occurs in Cores 17 and 18 . The base of this zone is defined by the first occurrence of $R$. barboi, which occurs in Sample 555$18, C C$. Other species present include $D$. punctata var. hustedtii, $R$. praebarboi, $A$. ingens, and $A$. ellipticus.

Cores 19 through 21 are assigned to the Denticulopsis nicobarica Zone based on the presence of $D$. nicobarica and $D$. punctata var. hustedtii below the first occurrence of $R$. barboi. Additional species present include Asterolampra marylandica, $R$. miocenica, Craspedodiscus coscinodiscus, and Actinocyclus ingens.

Rare specimens of C. lewisianus are found in Samples 555-21,CC and 555-22-1, $106 \mathrm{~cm}$. Therefore these samples are placed within the Coscinodiscus lewisianus Interval. The remaining portion of Core 22 is poorly preserved, and only specimens of $A$. ingens are observed.

All other samples below Core 22 with the following exceptions are barren of diatoms. Core 27 contains fragments of the Eocene diatom Stephanopyxis sp. Samples 555-32,CC, 555-41,CC, 555-48, CC, 555-58, CC, 555$59, \mathrm{CC}, 555-61, \mathrm{CC}$, and 555-67, CC contain undiagnostic pyritized diatom frustules. Figure 9 shows that an average sedimentation accumulation rate of $2.5 \mathrm{~cm} / 1000 \mathrm{yr}$. occurs for the middle and late Miocene of Hole 555.

\section{PALEOCEANOGRAPHY}

The eight holes drilled during Leg 81 can be correlated by diatom datums (see Fig. 10). With the exception of Hole 552A, which was hydraulically piston cored, all holes were rotary drilled. Diagnostic diatoms occur in the lower Eocene to Holocene sediments.

With the exception of an unconformity in the Pliocene of Hole 555 (see Backman, this volume), all recognized unconformities are early Miocene or older in age. Unconformities are concentrated in the middle Eocene 


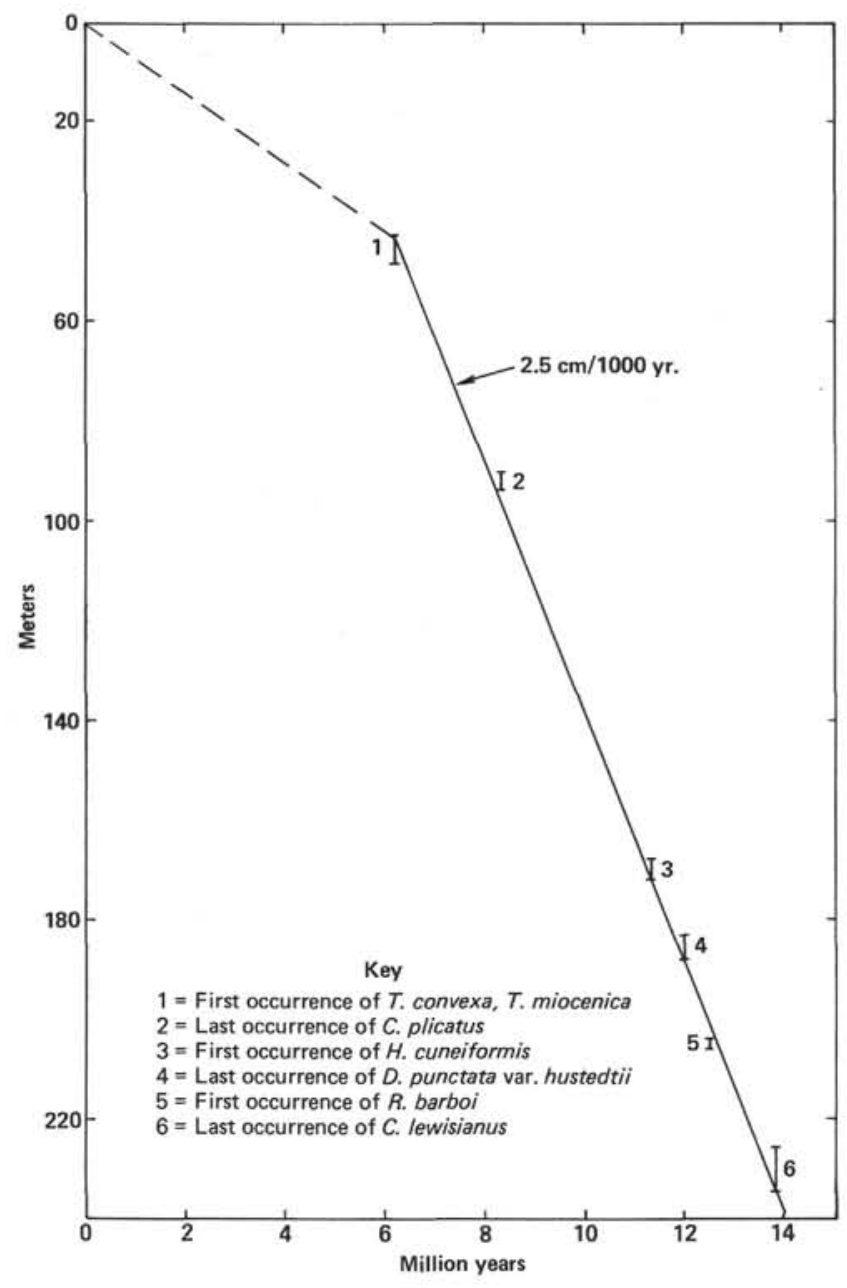

Figure 9. Sediment accumulation rate curve calculated for Hole 555 from diatom datum levels.

to middle Miocene sediments of Hole 553A. Samples observed within this interval are partially dissolved of diatoms. However, the presence of Actinocyclus ingens and Rocella gelida in this interval allows recognition of upper Oligocene to middle Miocene sediments. The concentration of unconformities within this $30-\mathrm{m}$ interval may reflect the subsidence of the Iceland Faroe Ridge and erosion of sediments at Hole 553A by the southward-flowing Norwegian Sea Bottom Water.

Two distinct intervals of dissolution are present within Leg 81 material. The oldest occurs in the late Miocene Nitzschia porteri-Nitzschia miocenica Interval and the youngest occurs in the late Pliocene to Pleistocene Nitzschia marina and Pseudoeunotia doliolus Zones. With the exception of middle Eocene sediments at Holes 552, $552 \mathrm{~A}$, and 553A, and middle to upper Miocene sediments at Hole 555, samples examined below the base of the Thalassiosira convexa Zone are generally barren of diatoms. This abrupt change in diatom preservation from samples containing a well-preserved assemblage above to samples dissolved or barren of diatoms below correlates with the interval between the first occurrence of $T$. praeconvexa and the first occurrence of $T$. convexa and $T$. miocenica. These datums allow this preservational change to be correlated with the uppermost portion of Epoch 6 and assigned an age of approximately $6.2 \mathrm{~m}$.y. ago. This assigned age corresponds to the age suggested by Haq et al. (1980) for a late Miocene marine carbonisotope shift. This carbon shift, which is a decrease in the concentration of benthic foraminiferal ${ }^{13} \mathrm{C}$, is recorded in sediments from the Pacific (Keigwin, 1979; Bender and Keigwin, 1979), the Indian (Vincent et al., 1980), and the South Atlantic (Haq et al., 1980) oceans. At present this carbon shift is not recorded in North Atlantic sediment (Shackleton and Cita, 1979; Keigwin, pers. comm., 1984).

The change in diatom preservation within the late Miocene of the Rockall Plateau Region may reflect an increase in the nutrient supply within the surface waters resulting from changes in oceanic circulation. Such changes are conclusive to an increase in phytoplankton productivity, resulting in an increase in the supply rate of diatom frustules to the ocean floor, which would be reflected by an increase in diatom preservation.

The second interval of dissolution occurs within the Pliocene-Pleistocene, Nitzschia marina, and Pseudoeunotia doliolus Zones. Samples examined within this interval contain abundant ice-rafted detritus. The first major occurrence of ice-rafted detritus within the lower portion of this interval suggests that the base of this interval approximates the initiation of Northern Hemispheric glaciation within the Rockall Plateau Region. Within the Rockall Plateau Region this event has an age slightly younger than the last occurrence of $N$. jouseae at $2.65 \mathrm{~m} . \mathrm{y}$. ago.

Although occasional samples in this dissolution interval contain a well-preserved diatom flora, the majority of samples examined are barren of diatoms. This dissolution interval is included in a detailed study completed on the upper $50 \mathrm{~m}$ of sediment recovered from Hole 552A (see Zimmerman et al., this volume).

Figure 11 compares the fluctuation in diatom abundance to the fluctuation in ${ }^{18} \mathrm{O}(\%)$, as obtained from the test of benthic foraminifers for the upper $55 \mathrm{~m}$ of Hole 552A. The interval from approximately 24 to $29 \mathrm{~m}$ (Core 6) is not included within this study because of the disturbed nature of the sediment.

Useful biostratigraphic datums for this study are as follows: Datum 1 (see Fig. 11) - the presence of the silicoflagellate species Mesocena quadrangula and the diatom species $N$. fossilis in Sample 552A-5-1, $90 \mathrm{~cm}(19.9 \mathrm{~m}$ depth) suggests that this sample is older than the last occurrence of these species, which occurs at approximately 0.79 m.y. ago. This sample occurs at the base of the Jaramillo Event and therefore can be assigned a more precise age of approximately 0.91 m.y. ago. Datum 2 (see Fig. 11)-the last occurrence of $T$. convexa at Sample 552A-9-1, $63 \mathrm{~cm}$ (39.6 m depth) occurs between the Gauss/Matuyama boundary and the Olduvai Event, which indicates an age of approximate $2.2 \mathrm{~m}$.y. ago for this datum. This age agrees with the results of Burckle and Trainer (1979), who assigned an age of 2.2 m.y. ago for this event in Core V28-179 from the central equatorial Pacific. Datum 3 (see Fig. 11) - the last occurrence of $N$. jouseae in Sample 552A-10-1, $30 \mathrm{~cm}(40.8 \mathrm{~m}$ 


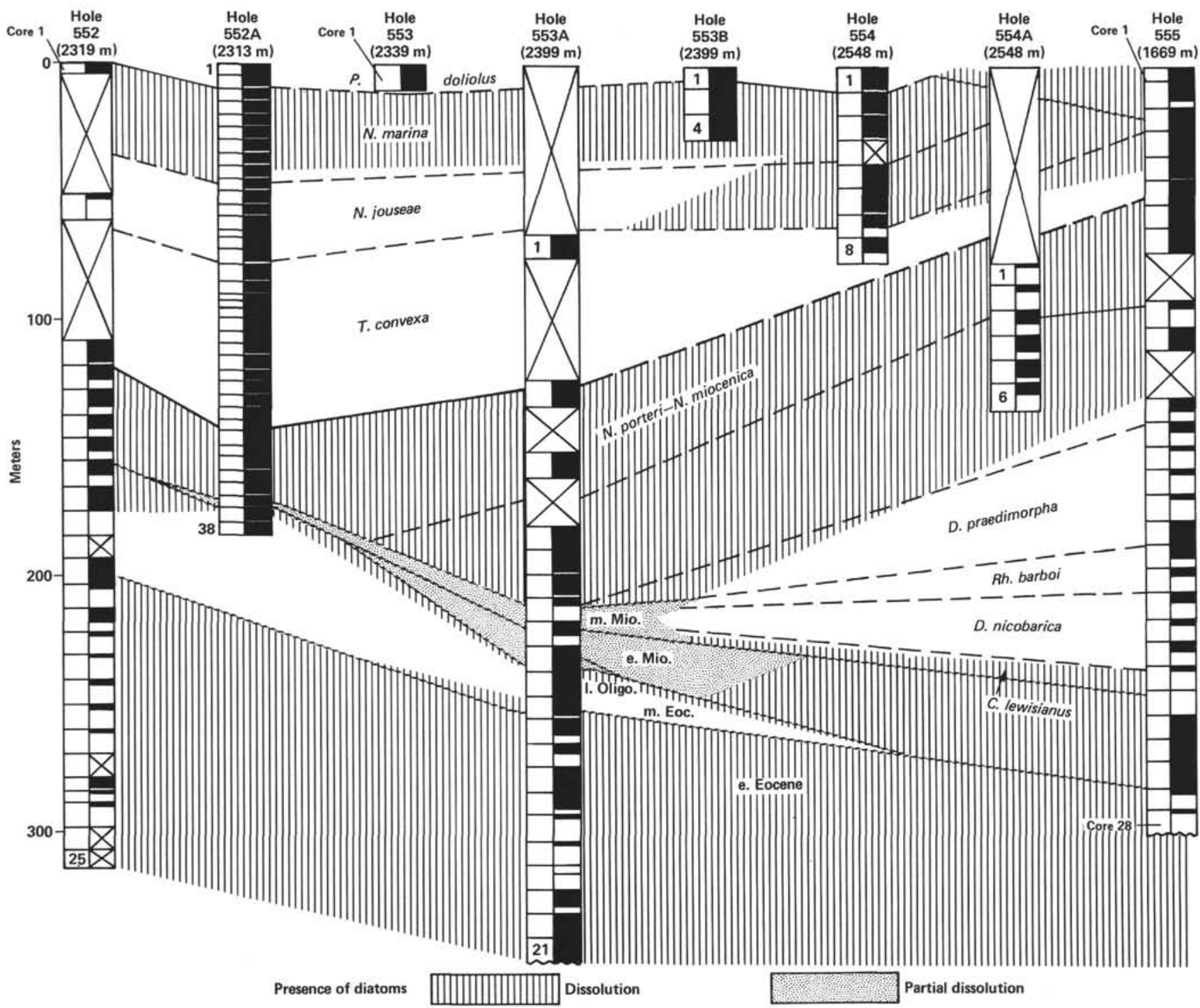

Figure 10. Correlation of age and zonal determinations between Leg 81 holes. (Correlations of zonal boundaries used during Leg 81 are represented by horizontal lines. Solid lines indicate that zonal boundaries are observed in both holes. Dashed lines indicated correlations that are tentative because dissolution and the lack of recovered material prevented accurate placement of zonal boundaries. Shaded areas represent intervals of generally poor preservation.)

depth) falls within the upper portion of the Gauss Paleomagnetic Epoch and has an approximate age of 2.65 $\mathrm{m} . y$. ago. Once again this is in agreement with the results of Burckle and Trainer (1979) (see Fig. 6). Datum A represents the last occurrence of Rhizosolenia curvirostris within the Rockall Plateau Region. Donahue (1970) and Schrader (1973) have estimated the extinction of $R$. curvirostris to occur in the North Pacific at approximately 0.26 m.y. ago. Kanaya and Koizumi (1970) have assigned an age of 0.25 m.y. ago for this datum. Within the Rockall Region the last occurrence of $R$. curvirostris in Sample 552A-2-2, $52 \mathrm{~cm}$ is older than previously estimated for the North Pacific Region, as it correlates with oxygen isotope Stage 10 in the North Atlantic. Shackleton and Opdyke $(1973,1976)$ have estimated the isotope $9 / 10$ stage boundary at 0.35 m.y. ago and the $10 / 11$ isotope stage boundary at $0.37 \mathrm{~m} . \mathrm{y}$. ago. Therefore, by extrapolation, the last occurrence of $R$. cur- virostris within the Rockall Region occurs at approximately $0.36 \mathrm{~m} . y$. ago. The paleomagnetic results figured here (Fig. 11) for the uppermost portion of Hole 552A are from a study by Kent (see Zimmerman et al., this volume).

The diatom abundance curve (Fig. 11) generally compares with Shackleton's oxygen-isotope curve. Samples with common diatoms compare to samples that have a low ${ }^{18} \mathrm{O}$ content, whereas samples barren of diatoms correspond to samples with a higher ${ }^{18} \mathrm{O}$ content. However, this is only true for the interval (Interval 1) above $7.2 \mathrm{~m}$ (younger than approximately $0.44 \mathrm{~m}$.y. ago) and the interval (Interval 3) below $33 \mathrm{~m}$ (older than approximately 1.8 m.y. ago). The intermediate interval (Interval 2) is generally barren of diatoms.

Within Intervals 1 and 3, samples that are fairly abundant of diatoms correspond to samples representing interglacial conditions. Samples within these intervals that 


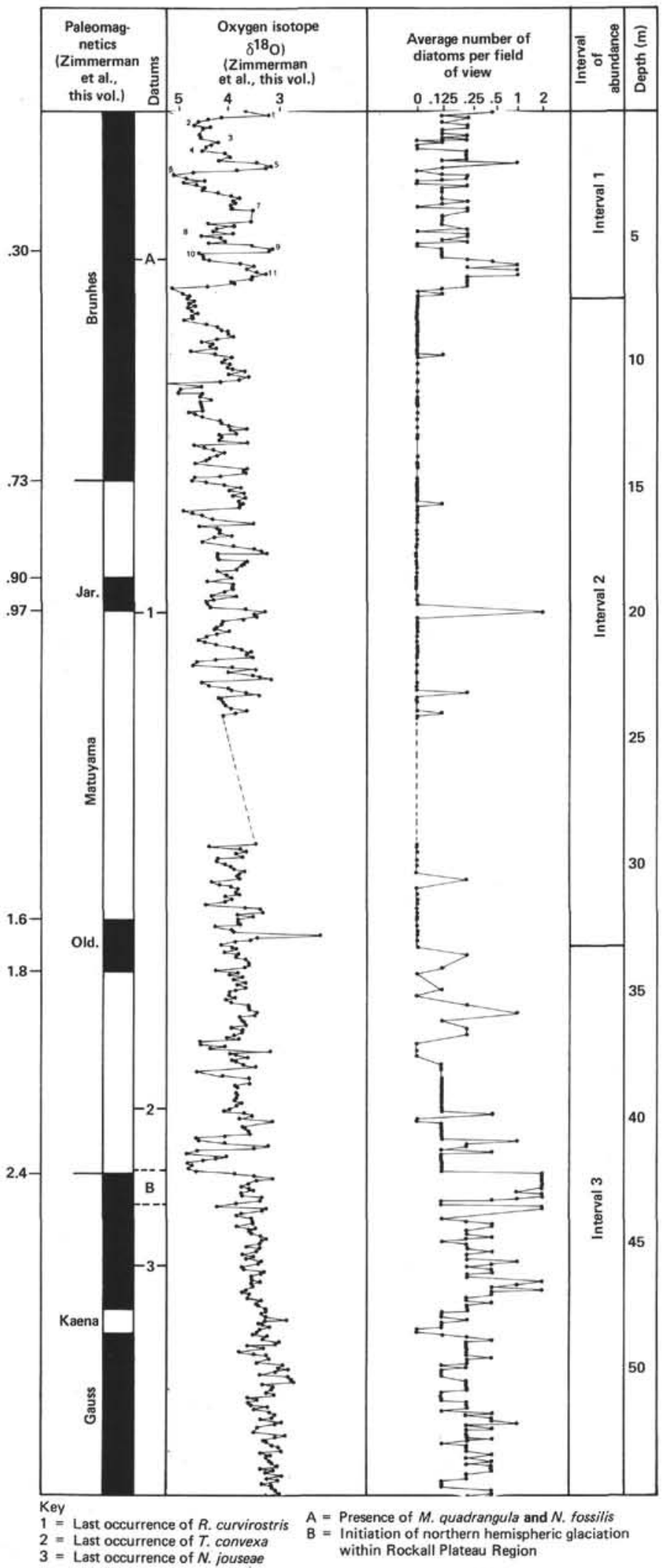

Figure 11. Correlation between the paleomagnetic results of Kent (see Zimmerman et al., this volume), the oxygen-isotope results of Shackleton (this volume), and the diatom abundance for Hole 552A. 
contain rare (or are barren of) diatoms correspond to samples representing glacial conditions. This can be readily seen by comparing the interglacial oxygen isotope Stages 1,5 , and 11 with samples that have a high diatom abundance. However, isotope Stage 9 does not correspond with the diatom-abundance curve. Likewise, glacial isotope Stages 2 through 10 correlate with samples having rare diatoms or samples that are barren of diatoms.

Similar correspondence occurs in Interval 3. The lowest portion $(45-55 \mathrm{~m})$ of this interval is characterized by comparatively small isotope fluctuations with a similar and somewhat less fluctuating diatom-abundance curve. The $\mathrm{O}^{18}$ curve first begins to have larger variability at approximately a depth of $44 \mathrm{~m}$ (Datum B), with the first major isotope shift occurring at a depth of $42 \mathrm{~m}$. This shift may represent the initiation of northern hemispheric glaciation which would have an approximate age of 2.4 m.y. ago within the Rockall Region. At exactly the same depth, a major shift occurs from samples abundant in diatoms (preglacial) to samples barren of diatoms at the glacial event.

The correspondence within Intervals 1 and 3 (Fig. 11), between samples containing abundant diatoms with interglacial conditions and samples barren of diatoms with glacial conditions, suggests that diatom abundance within the Rockall Region is controlled by the latitudinal migration of surficial water masses during climatic cycling. This interpretation is not new and has been cited by numerous workers involving several microfossil groups (McIntyre et al., 1972; CLIMAP, 1976; Ruddiman, 1977; Ruddiman and McIntyre, 1976, 1981; Ruddiman et al., 1977, 1980).

However, the diatom abundance within Interval 2 (Fig. 11) does not correspond to the isotope curve. Although the majority of samples examined from this interval are barren of diatoms, occasional samples do contain a well-preserved diatom assemblage. Interval 2 extends from the middle of the Olduvai Event to the oxygen isotope Stage 11/12 boundary. Therefore an approximate age of 1.8-0.44 m.y. can be extrapolated for this interval.

It appears reasonable to suggest that the pattern observed in Interval 2 is caused by alterations in productivity and/or preservational factors. These alterations are the probable result of a set of complex changing oceanographic and climatic conditions. Any hypothesis proposed at this time to explain this pattern would be pure speculation because of the very limited data available.

However, one should point out that a "glacial sequence" that may be similar to Interval 2 is recorded by Schrader and Fenner (1976) at Sites 336, 346, 348, and 349 in the Norwegian Sea. Samples examined from these sequences are typically barren of diatoms but contain abundant terrigenous material. Occasional samples are recorded that contain a warm temperate diatom assemblage. Schrader and Fenner (1976) suggested these occasional samples represent periods when North Atlantic Drift waters penetrated into the Norwegian Sea Region.

Further studies are required to determine the relationship between these "glacial sequences" from the Nor- wegian Sea and Interval 2 from the Rockall Region. A positive relationship between these sequences would suggest that these intervals are the result of wide geographic changes rather than the result of local isolated events.

\section{CONCLUSION}

A middle Miocene to Holocene diatom zonation is developed from material recovered from the Rockall Plateau Region. This zonation is partially adapted from the diatom zonation defined by Burckle (1972) for the equatorial Pacific and is correlated to both the low-latitude Atlantic and Pacific oceans.

Two intervals of dissolution are recognized within the Rockall Region. A late-Miocene interval is associated with the base of the Thalassiosira convexa Zone and is present at all sites. The top of this interval correlates with the uppermost portion of paleomagnetic Epoch 6 and is assigned an age of approximately $6.2 \mathrm{~m}$.y ago. This preservational change may correspond to alteration of oceanic circulation resulting in changes in the rate of productivity.

An interval of dissolution is recognized in PliocenePleistocene material examined from Hole 552A. Diatom abundance in Hole 552A typically corresponds to fluctuating climatic conditions. Diatoms are most abundant during interglacial intervals and rare or absent during glacial intervals. However, diatom abundance in the Rockall Region for the interval from approximately 1.8 to 0.44 m.y. ago does not correspond to climatic fluctuations. Samples examined within this interval are typically barren of diatoms. However, rare samples were observed to contain a well-preserved diatom assemblage.

Although further work is required to explain the Pliocene-Pleistocene Interval, this interval may correspond to a "glacial sequence" recognized by Schrader and Fenner (1976) within the Norwegian Sea.

\section{ACKNOWLEDGMENTS}

I wish to thank John Barron, Jan Backman, Charolette Brunner, Lloyd Burckle, and James Gardner for helpful discussion throughout the course of this study and for taking the time to review this manuscript. Furthermore I wish to thank Dave Roberts, Detmar Schnitker, and all Leg 81 participants for the productive, rewarding experience aboard the Glomar Challenger. Appreciation is due further to Kenji Sakamoto and Karen Baldauf for photography and to Marion Anderson for typing. I also wish to thank John Barron for use of comparative material from DSDP Site 408 and the National Science Foundation for providing material from DSDP Hole 332.

\section{REFERENCES}

Abbott, W. H., 1978. Correlation and zonation of Miocene strata along the Atlantic margin of North America using diatoms and silicoflagellates. Mar. Micropaleontol., 3:15-34.

Akiba, F., 1979. The morphologies of Denticula dimorpha and its allied species, and the Neogene diatom biostratigraphy of Japan. Japan Petroleum Exploration Company, Tech. Res. Inst. Rep., 22: 148-189.

Andrews, G. W., 1978. Marine diatom sequence in Miocene strata of the Chesapeake Bay region, Maryland. Micropaleontol., 24(4): 371-406, pls. 1-8.

Azpeitia, D. F. Moros, 1911. La Diatomologia Espanola en los Comienzos des Siglo XX. Assoc. espanola para el progreso de las ciencias, Congr. de Zaragoza 4.

Bailey, J. W., 1842. A sketch of the infusioia of the family Bacillaria, etc. Am. J. Sci., 42:88-105. 
1856. Notice of microscopic forms in the Sounding of the Sea of Kamatschatka. Am. J. Sci., 22(Ser. 2):1-6.

Baldauf, J. G., and Barron, J. A., 1980. Actinocyclus ingens var. nodus: A new stratigraphically useful diatom of the circum-North Pacific. Micropaleontol., 26(1):103-110, pl. 1.

1982. Diatom biostratigraphy and paleoecology of the type section of the Luisian Stage, central California. Micropaleontol., 28(1):59-84, 7 pls.

Barron, J. A., 1976. Revised Miocene and Pliocene diatom biostratigraphy of upper Newport Bay, Newport Beach, California. Mar. Micropaleontol., 1:27-63.

1980a. Lower Miocene to Quaternary diatom biostratigraphy of Leg 57, off Northeastern Japan. In Scientific Party, Init. Repts. DSDP, 56, 57, Pt. 2: Washington (U.S. Govt. Printing Office), 641-685.

1980b. Upper Pliocene and Quaternary diatom biostratigraphy of Deep Sea Drilling Project Leg 54, Tropical Eastern Pacific. In Rosendahl, B. R., Hekinian, R., et al., Init. Repts. DSDP, 54: Washington (U.S. Govt. Printing Office), 455-462.

1981. Late Cenozoic diatom biostratigraphy and paleoceanography of the middle-latitude eastern North Pacific, Deep Sea Drilling Project Leg 63. In Yeats, R. S., Haq, B. U., et al., Init. Repts. DSDP, 63: Washington (U.S. Govt. Printing Office), 507-538.

in press. Neogene planktonic diatom biostratigraphy. In Saunders, J. B., and Bolli, H. M. (Eds.), Biostratigraphy by Marine Plankton: Cambridge (Cambridge University Press).

Bender, M. L., and Keigwin, L. D., Jr., 1979. Speculations about the upper Miocene change in Abyssal Pacific dissolved bicarbonate ${ }^{13} \mathrm{C}$. Earth Planet. Sci. Lett., 45:383-393.

Brightwell, T., 1858. Remarks on the genus Rhizosolenia of Ehrenberg. Quart. J. Microsc. Sci. 1, 6:93-95.

1860. On some of the rarer or undescribed species of Diatomaceae. Part 1. Quat. J. Microsc. Sci., 7:179-181, pl. 9. Part 2, Vol. 8 , pp. 93-96, pl. 5, 6 .

Brun, J., 1890-1893. Le Diatomiste (Vol. I), (Journal special s'occupant exclusivement des Diatomees et de tout ce qui s'y rattache.) 1891. Diatomees especes nouvelles marines, fossiles ou pelagiques. Soc. Phys. Hist. Nat. Geneve Mem., 31:1-47.

Brun, J., and Tempère, J., 1889. Diatomees fossiles du Japon. Especes marines and nouvelles des calcaires argileux des Sendai et de Yedo. Soc. Phys. Hist. Nat. Geneve Mem., 30:1-75.

Bukry, D., 1973. Coccolith stratigraphy eastern equatorial Pacific, Leg 16 Deep Sea Drilling Project. In Van Andel, Tj. H., Heath, G. R., et al., Init. Repts. DSDP, 16: Washington (U.S. Govt. Printing Office), 653-711.

1978a. Cenozoic coccolith silicoflagellate, and diatom stratigraphy, Deep Sea Drilling Project Leg 44. In Benson, W. E., Sheridan, R. E., et al., Init. Repts. DSDP, 44: Washington (U.S. Govt. Printing Office), 807-863.

1978b. Cenozoic silicoflagellate and coccolith stratigraphy, north western Atlantic Ocean, DSDP Leg 43. In Benson, W. E., Sheridan, R. E., et al., Init. Repts. DSDP, 44: Washington (U.S. Govt. Printing Office), 775-805.

1980. Eocene diatom and siliceous sponge spicules from the Northwestern Atlantic Ocean, DSDP Site 417 and 418. In Donnelly, T., Francheteau, J., Bryan, W., Robinson, P., Flower, M., Salisbury, M., et al., Init. Repts. DSDP, 51, 52, 53, Pt. 2: Washington (U.S. Govt. Printing Office), 851-855.

Burckle, L. H., 1969. Late Cenozoic planktonic diatom zones in equatorial Pacific sediments. Geol. Soc. Am. Bull., 7:24. (Abstract)

1972. Late Cenozoic planktonic diatom zones from the eastern equatorial Pacific. Nova Hedw., Beihft., 39:217-250.

1977. Pliocene and Pleistocene diatom datums from the equatorial Pacific. Republic of Indonesia. Geol. Res. Devel. Centre, Spec. Publ., 1:25-44.

, 1978a. Marine diatoms. In Haq, B., and Boerisma, A. (Eds.), Introduction to Marine Micropaleontology: New York (Elsevier, North Holland Inc.), pp. 245-266.

1978b. Early Miocene to Pliocene diatom datum levels for the equatorial Pacific. Republic of Indonesia. Geol. Res. Devel. Centre, Spec. Publ., 1:25-44.
Burckle, L. H., and Opdyke, N. D., 1977. Late Neogene diatom correlations in the circum-Pacific. Proc. First Intl. Congr. Pacific Neogene Stratigraphy, Tokyo, 1976, pp. 255-284.

Burckle, L. H., and Trainer, J., 1979. Middle and late Pliocene diatom datum levels from the central Pacific. Micropaleontol., 25(3): 281-293.

Castracane, C. A., 1886. Report on the scientific results of the voyage of H.M.S. Challenger during the years 1873-76. Repts. Voy. Challenger, Botany, 2:1-178, pls. 1-23.

Chyong Ngok, A., 1971. Tropic Atlantic phytoplankton. Oceanology, 11:896-901.

Cita, M. B., 1975. The Miocene/Pliocene boundary: History and definition. In Saito, T., and Burckle, L. H. (Eds.), Late Neogene Epoch Boundaries: New York (Micropaleontology Press), pp. 1-30.

Cleve, P. T., 1900. The plankton of the North Sea, the English Channel and the Skagerak in 1899. K. Sven. Vetenskapsakad. Handl. Bandet, 34(2).

1904. Plankton table for the North Sea. Cons. Expl. Mer. Bull., 1903-1904.

Cleve, P. T., and Grunow, A., 1880. Beitrage zur Kenntnis der arktischen Diatomeen. K. Sven. Vetenskapsakad. Handl., 17:3-122.

Cleve, P. T., and Moller, J. D., 1877-1882. Diatoms (Exsiccata): Uppsala.

CLIMAP Project Members, 1976. The surface of the ice-age Earth. Science, 191:1131-1144.

DeToni, J. B., 1891-1894. Sylloge algarum omnium hucusque cognitarum (Vol. 2), Bacillarieae, Sectio I, Raphideae, pp. 1-490 (1891). Sectio II, Pseudoraphideae, pp. 491-817 (1892)., Sectio III, Cryptoraphideae, pp. 818-1556 (1894), Typis Seminarii, Patavii.

Donahue, J. G., 1970. Pleistocene diatoms as climatic indicators in Nortn Pacific sediments. Mem. Geol. Soc. Am., 126:121-138.

Dzinoridze, R. N., Jousé, A. P., Koroleva-Golikova, G. S., Kozlova, G. E., Nagaeva, G. S., Petraschvskaya, M. G., and Strelinikova, N. I., 1979. Diatom and radiolarian Cenozoic stratigraphy, Norwegian basin, DSDP Leg 38. In Supko, P. R., Perch-Nielsen, K., et al., Init. Repts. DSDP, Suppl. to Vols. $38,39,40$, and 41 : Washington (U.S. Govt. Printing Office), 289-427.

Ehrenberg, C. G., 1838. Die infusionsthierchen als vollkommende Organismen. Ein Blick in das tiefere organische Leben der Natur: Leipzig (Leopold Voss), 1-548, pls. 1-64.

1839. Uber nach jetzt zahlreich lebende Thierarten der Kreidebildung und den Organismus der Polythalamien. $A b h$. Akad. Wiss. Berlin, pp. 81-174.

1841a. Uber Verbreitung und Einfluss des mikroskopischen Lebens in Sudund Nord-Amerika. Verh. K. Preuss. Akad. Wiss. Berlin, pp. 139-144.

1841b. Verbreitung und Einfluss des mikroskopischen Lebens in Sud- und Nord-Amerika. Abh. Akad. Wiss. Berlin, 1:291442, 4 Taf. (Sonderabdruck 154 S.).

1844a. Uber zwei neue Lager von Gebirgsmassen aus Infusorien als Meeres-Absatz in Nord-Amerika und eine Vergleichung derselben mit den organischen Kreide-Gebiden in Europa und Afrika. Verh. Akad. Wiss. Berlin, 1844:57-97.

1844b. Untersuchungen uber die kleinsten Lebensformen im Quellenlande des Euphrats und Araxes, so wie uber eine and neuen Tormen sehr reiche, marine Tripelbildung von den Bermuda-Inseln. Verh. Akad. Wiss. Berlin, 1844:253-275.

$1844 \mathrm{c}$. Einige vorlaufige Resultate der Untersuchungen der von der Sudpolreise des Capitain Ross, so wie in den Herren Schayer und Darwin zugekommenen materialien Uber das verhalten des kleinsten Lebens in den Oceanen und den grossten bisher zuganglichen Tiefen des Weltmeers vor. Bericht Uber die zur Bekanntmachung geeigneten. Verh. Akad. Wiss. Berlin, pp. 182-207.

1854-1856. Mikrogeologie Das Erden und felsen schaffende Wirken des unsichtbar kleinenselbststandigen Lebens auf der Erde: Leipzig (Leopold Voss) (1854).

Fenner, J., 1977. Cenozoic diatom biostratigraphy of the equatorial and southern Atlantic Ocean. In Supko, P. R., Perch-Nielsen, K., et al., Init. Repts. DSDP, Suppl. to Vols. 38, 39, 40, and 41: Washington (U.S. Govt. Printing Office), 491-623.

Forti, D. A., 1909. Studi per una monografia del genere Pyxilla (diatomee) e dei generi affini. Nuova Notarisia, 20:5-24. 
Frenguelli, J., 1949. Diatomeas fosiles de los yacimientos chilenos de Tiltil y Mejillones. Darwiniana, 9:97-157.

Gardette, D., 1979. Arport de laetude des diatomees et des silicoflagettes a la Biostratigraphic et a la reconstitution du msessinjen de mediterranee: Analyse de grelgnes tripolis du passage Mio-Miocene a chypre, en crete et an maroc [Ph.D. dissert.]. Université de Paris and Centre d'Orsay, Paris.

Gersonde, R., 1979. Diatoms in the Mediterranean Neogene, a short review. In Bizon, G. and Muller, C. (Eds.), Report of the Working Group on Micropaleontology, Ann. Geol. Pays Hell, Tome hors serie, Fasc. E, pp. 1348-1362.

1980. Palaookologsche und biostratigraphische Auswertung von diatomeenassoziationen aus dem Messinium des Caltauissettabeck ens (Sizilien) und einiger Vergleichs-profile in So-Spainen, NW-Algerien und Auf-Kreta. [Dissertation zur Erlangung des Doktorgrades der Mathematisch-Naturwissenschaftlizhen Fakultat]. Christian-Albrechts-Universitat za kiel.

Gombos, A. M., Jr., and Ciesielski, P., 1983. Late Eocene to early Miocene diatoms from the southwest Atlantic. In Ludwig, W. J., Krasheninnikov, V. A., et al., Init. Repts. DSDP, 71: Washington (U.S. Govt. Printing Office), 583-634.

Gran, H. H., 1904. Die Diatomeen der Arktischen Meere, I. Die Diatomeen des Planktons in "Fauna Arctica" auf Grund der Erg. der deutschen Expedition in das Nordliche Eismeer im Jahre 1898. Bd. 4, 511-554.

Gregory, W., 1857. On new forms of marine Diatomaceae found in the Firth of Clyde and in Loch Fyne, illustrated by numerous fig ures drawn by R. K. Greville. R. Soc. Edinburgh, Trans., 21: 473-542.

Greville, R. K., 1859. Descriptions of diatomaceae observed in Californian Guano. Quat. J. Microsc. Sci., 7:155-166. 1866. Descriptions of new and rare diatoms. Microsc. Soc. London Trans., 14:1-9, 77-86, 121-130.

Greville, R., and Arnott, G. W., 1857. On new forms of marine Diatomaceae found in the Firth of Clyde and in Loch Fyne. R. Soc. Edinburgh, Trans., 21:473-542.

Grove, E., and Sturt, G., 1887. On a fossil marine diatomaceous deposit from Oamaru, Otago, New Zealand-Appendix. J. Queckett Microsc. Club, 2nd ser., 3:131-148.

Grunow, A., 1866. Uber Stephanogonia danica n. sp. Grun. Hedwigia, 5:146.

1868. Algae in Reise Seiner Majestat Fregatte "Novara" um die Erde in den Jahren 1857, 1858, 1859. Bot. Teil, 1:1-104. 1884. Die Diatomeen von Franz-Josefs-Land. Denkschr.

Math.-Naturw. Classe Kaiserl. Akad. Wiss., 48:53-112. 1886. Diatomaceae. In U. Martelli (Ed.), Florula Bogosensis, Firenze.

Hailwood, E., Bock, W., Costa, L., Dupeuble, P., Müller, C., and Schnitker, D., 1979. Chronology and biostratigraphy of Northeast Atlantic sediments DSDP Leg 48. In Montadert, L., Roberts, D. G., et al., Init. Repts. DSDP, 48: Washington (U.S. Govt. Printing Office), 1119-1142.

Hajós, M., 1976. Upper Eocene and lower Oligocene diatomaceae, Archaeomoaaduzeae, and Silicoflagellate in Southwestern Pacific sediments, DSDP Leg 29. In Hollister, C. D., Craddock, C., et al., Init. Repts. DSDP, 35: Washington (U.S. Govt. Printing Office), 817-883.

Hanna, G., 1930. A review of the genus Rouxia. J. Paleontol., 2: 179-188.

1932. The diatoms of Sharktooth Hill, Kern County, California. Calif. Acad. Sci. Proc., 20:161-263.

Haq, B. U., Berggren, W. A., and Van Couvering, J. A., 1977. Correct age of the Pliocene-Pleistocene Boundary. Nature, 269:483-488.

Haq, B. U., Worsley, T. R., Burckle, C. H., Douglas, R. G., Keigwin, L. D., Jr., Opdyke, N. D., Savin, S. M., Sommer, M. A., II, Vincent, E., and Woodruff, F., 1980. Late Miocene marine carbonisotope shift and synchroneity of some phytoplanktonic biostratigraphic events. Geology, 8:427-431.

Hasle, G. R., 1960. Phytoplankton and ciliate species from the tropical Pacific. Skr. Nor. Videns. Akad. [Kl.] 1 Mat. Naturvidensk Kl $1960,2: 1-50$.

Hasle, G. R., and Fryxell, G., 1977. The genus Thalassiosira and some species with a linear aveola array. Nova Hedwigia Beih., 54:15-66.
Hass, D., and Schrader, H. J., 1979. Neogene coastal upwelling history off northwest and southwest Africa. Marine Geol., 29:39-53.

Hendey, N. I., 1969. Pyrgapyxis a new genus of diatom from a South Atlantic Eocene core. Occ. Pap. Calif. Acad. Sci., San Francisco, 72:1-5.

Hustedt, F., 1927-1966. Die Kieselalgen Deutschlands, Osterreichs und der Schweiz. Band 7 of Rabenhorst, F. L., Kryptogamenflora. Leipzig: Akad. Verlagsges., Pt. 1:1-920, figs. 1-542, 1927-1930; Pt. 2: 1-845, figs. 543-1179, 1931-1959; Pt. 3:1-816, figs. 1180-1788, $1962-1966$.

Jorgensen, E. G., 1905. The Protist plankton and the diatoms in bottom samples. In O. Nordgaard (Ed.), Hydrographical and Biological Investigations in Norwegian Fiords: Bergens Museum Skrift. Bergen (John Grieg).

Jousé, A. P., 1959. Principal development stages of marine diatoms of the far east in the Tertiary and Quaternary periods. Bot. Zh. (Botanical Journal), 44(1):44-55.

(Ed), 1977. Atlas of Microorganisms in Bottom Sediments of the Oceans: Moscow (Nauka).

Kanaya, T., 1959. Miocene diatom assemblages from the Onnagawa Formation and their distribution in the correlative formations in northeast Japan. Sci. Rept. Tohoku Univ., 30:130.

1971. Some aspects of pre-Quaternary diatoms in the oceans. In Funnell, B. M., and Riedel, W. R. (Eds.), The Micropaleontology of Oceans: Cambridge (Cambridge Univ. Press), pp. 545-565.

Kanaya, T., and Koizumi, I., 1970. The progress in the younger Cenozoic diatom biostratigraphy in the Northern Circum-Pacific region. J. Mar. Geol. (Japan), 6(2):47.

Keigwin, L., 1979. Late Cenozoic stable isotope stratigraphy and paleoceanography of DSDP sites from the east equatorial and north central Pacific Ocean. Earth Planet. Sci. Lett., 45:361-382.

Kitton, I. A., 1870-1871. On diatomaceous deposits from Jutland. $J$. Queckett Microsc. Club, 2:99-102 (Pt. 1), pp. 168-171.

Koizumi, I., 1968. Tertiary diatom flora of Oga Peninsula, Akita Prefecture, northeast Japan. Sci. Rept. Tohoku Univ., 2nd ser. (Geology), 40:171-225.

1973. The late Cenozoic diatoms of Sites 183-193, Leg 19. In Creager, J. S., Scholl, D. W., et al., Init. Repts. DSDP, 19: Washington (U.S. Govt. Printing Office), 805-855.

1975a. Neogene diatoms from the western margin of the Pacific Ocean, Leg 31, Deep Sea Drilling Project. In Karig, D. E. Ingle, J. C., Jr., et al., Init. Repts. DSDP, 31: Washington (U.S. Govt. Printing Office), 779-819.

1975b. Neogene diatoms from the northwestern Pacific Ocean, Deep Sea Drilling Project. In Larson, R. L., Moberly, R., et al., Init. Repts. DSDP, 32: Washington (U.S. Govt. Printing Office), $865-889$.

1980. Neogene diatoms from the Emperor Seamount chain, Leg 55, Deep Sea Drilling Project. In Jackson, E. D., Koizumi, I., et al., Init. Repts. DSDP, 55: Washington (U.S. Govt. Printing Office), 387-407.

Koizumi, I., and Kanaya, T., 1976. Late Cenozoic marine diatom sequence from Chosi district, Pacific coast, central Japan. In Takayanagi, Y., and Saito, T., (Eds.), Progress in Micropaleontology: New York (Micropaleontology Press), pp. 144-159.

Kolbe, R. W., 1954. Diatoms from equatorial Pacific cores. In Petterson, H. (Ed.), Rept. Swed. Deep-Sea Exped. 1947-1948, 6(1): $3-57$.

1957. Fresh-water diatoms from Atlantic deep-sea sediments. Science, 126(3282):1053-1056.

Korotkevicz, O., 1964. Species novae diatomacearum e Neogene Peninsulae Kamszatka. Nov. System. Plant. non Vascularium (Akademia Scientiarum U.R.S.S., Institutum Botanicum Nomine V. L. Komarovii), 1964, pp. 104-114.

Kutzing, F., 1844. Die kieselschaligen Bacillarien oder Diatomeen. Nordhausen.

LaBrecque, J. L., Kent, D. V., and Cande, S. C., 1977. Revised magnetic polarity time scale for late Cretaceous and Cenozoic time. Geology, 5:330-335.

Lauder, H. S., 1864. On New Diatoms. Trans. Microsc. Soc. London, 12:6-8, pl. III. 
Lohman, K. E., 1938. Pliocene Diatoms from the Kettleman Hills, California. U.S. Geol. Surv., Prof. Pap., 189-C, pp. 81-102. 1941. Geology and Biology of North Atlantic Deep-Sea Cores, etc. Pt. 3: Diatomaceae. U.S. Geol. Surv. Prof. Pap., 196-B, pp. 55-86.

McIntyre, A., Ruddiman, W. F., and Tantzen, R., 1972. Southward penetrations of the North Atlantic Polar Front: Faunal and floral evidence of large scale surface water mass movements over the last 225,000 years. Deep-Sea Res., 19:61-77.

Martini, E., 1971. Standard Tertiary and Quaternary calcareous nannoplankton zonation. In Farinacci, A. (Ed.), Proc. Second Planktonic Conf., Roma, 1970 (Vol. 2): Rome (Edizioni Tecnoscienza), 739-777.

Maynard, N. G., 1976. Relationship between diatoms in surface sediments of the Atlantic Ocean and the biological and physical oceanography of overlying waters. Paleobiology, 2:99-121.

Muchina, V. V., 1965. New species of diatoms from the bottom sediments of the equatorial region of the Pacific (in Russian). Nov. System. Plant. non Vascularium, Bot. Inst. Adad. Nauk SSSR, pp. 22-25.

Ness, G., Shaul, L., and Coach, R., 1980. Marine magnetic anomaly timescale for the Cenozoic and Late Cretaceous: A precis, critique, and synthesis. Rev. Geophys. Space Phys., 18(4):753-770.

Nitzsch, C. L., 1817. Beitrag zur Infusorienkunde oder Naturbeschreibung der Zerkarien und Bazillarien. Neue Schriften der naturforschenden Gesellschaft zu Halle, Bd. 3, Heft 1, 128 S., 6 Tab. Handel's Verlag, Halle.

O'Mears, E., 1869. On new forms of Diatomaceae from dredgings off the Arran Islands, Co. Galway. Quat. J. Microsc. Sci., new ser., 9: 150-151, pl. 12.

1876. Report on the Irish Diatomaceae. Proc. Roy. Irish Acad., second ser., 2:235-425, pl. 26-34.

Ostenfeld, C. H., 1900. Plankton. In M. Kundsen and C. Ostenfeld (Eds.), Iagttagelser over Overfladevandets Temperature, Saltholdighed og Plankton paa islandske og gronlandske Skibsrouter in 1899: Kjobenhavn (Wandel), pp. 45-93.

Peragallo, H., 1892. Monographie du genre Rhizosolenia. Le Diatomiste, 1:99-117.

Pokras, E., 1981. Late Pleistocene paleo-oceanography of the Northern North Atlantic: Diatom evidence. Geol. Soc. of Amer., 94th annual meeting, 13(7):530. (Abstract with programs)

Proshkina-Lavrenko, A. J., 1949. Diatomovyj Analiz. Centrales Mediales. Bot. Inst. Akad. Nauk SSSR, 2:1-238.

Ralfs, J., 1861. In Pritchard, A. (Ed.), A History of Infusoria, Living and Fossil: London (Whittaker). (Edition IV, revised and enlarged by J. T. Arlidge, W. Archer, J. Ralfs, W. C. Williamson and the author).

Rattray, J., 1980a. A revision of the genus Actinocyclus Ehrenberg. J. Queckett Microsc. Club, 4:137-212.

$1890 \mathrm{~b}$. A revision of the genus Coscinodiscus Ehrb., and some allied genera. R. Soc. Edinburgh, Proc., 16:449-692.

Reinhold, T., 1937. Fossil diatoms from the Neogene of Java and their zonal distribution. Verh. Geol. Mijibouwokd. Genoot, Ned. Kolon, Gel., Ser. 12:93-133.

Riely, G., 1957. Phytoplankton of the North central Sargasso Sea. Limnol. Oceanogr., 2:252-270.

Roper, F. C., 1858. Notes on some species and varieties of British marine Diatomaceae. Ouat. J. Microsc. Sci., 6:17.

Ruddiman, W. F., 1977. Late Quaternary deposition of ice-rafted sand in the subpolar North Atlantic (1st $40^{\circ}$ to $65^{\circ} \mathrm{N}$ ). Geol. Soc. Am. Bull., 88:1813-1827.

Ruddiman, W. F., and McIntyre, A., 1976. Northeast Atlantic paleoclimatic changes over the past 600,000 years. In Cline, R. M., and Hays, J. D., (Eds.), Investigation of Late Quaternary Paleoceanography and Paleoclimatology, Mem. Geol. Soc. Am., 145, 201-220. 1981. The North Atlantic during the last deglaciation. $\mathrm{Pa}$ laeogeog., Palaeoclimatol., Palaeoecol., 35:145-214.

Ruddiman, W. F., Molfino, B., Esmay, A., and Pokras, E., 1980. Evidence bearing on the mechanism of rapid deglaciation. Clim. Change, 3:65-87.

Ruddiman, W. F., Sancetta, C. D., and McIntyre, A., 1977. Glacial/ interglacial response rate of subpolar North Atlantic waters to cli- matic change: The record left in deep-sea sediments. Philos. Trans. $R$. Soc. London B, 280:119-142.

Ryan, W. B. F., Cita, M. B., Rawson, M., Burckle, L. H., and Saito, T., 1974. A paleomagnetic assignment of Neogene stage boundaries and the development of isochronous datum planes between the Mediterranean, the Pacific and Indian Oceans in order to investigate the response of the world ocean to the Mediterranean "salinity crisis." Riv. Ital. Paleontol., 80:631-688.

Schmidt, A., et al., 1874. Atlas der Diatomaceenkunde: Leipzig (R. Reisland), Heft 1-120, Tafeln 1-460 (Taf. 1-216 A. Schmidt, 213216 M. Schmidt, 217-240 F. Fricke, 241-244 H. Heiden, 245-246 O. Muller, 247-256 F. Fricke, 257-264 H. Heiden, 265-268 F. Fricke, 269-472 F. Hustedt).

Schrader, H. J., 1973. Cenozoic diatoms from the northeast Pacific, Leg 18. In Kulm, L. D., von Huene, R., et al., Init. Repts. DSDP, 18: Washington (U.S. Govt. Printing Office), 673-797. 1974a. Cenozoic marine planktonic diatom stratigraphy of the tropical Indian Ocean. In Fisher, R. L., Bunce, E. T., et al., Init. Repts. DSDP, 24: Washington (U.S. Govt. Printing Office), 887-967.

1974b. Revised diatom stratigraphy of the experimental Mohole drilling, Gaudalupe Site. Calif. Acad. Sci., Proc., 39: 517-562.

1976. Cenozoic marine planktonic diatom biostratigraphy of the southern Pacific Ocean. In Hollister, C. D., Craddock, C., et al., Init. Repts. DSDP, 35: Washington (U.S. Govt. Printing Office), 605-671.

1977. Diatom biostratigraphy DSDP Project, Leg 37. In Aumento, F., Melson, W. G., et al., Init. Repts. DSDP, 37: Washington (U.S. Govt. Printing Office), 967-975.

1979. Opal phytoplankton in DSDP Leg 49 Samples. In Luyendyk, B. P., Cann, J. R., et al., Init. Repts. DSDP, 49: Washington (U.S. Govt. Printing Office), 589-593.

Schrader, H. J., and Fenner, J., 1976. Norwegian diatom biostratigraphy and taxonomy. In Talwani, M., Udintsev, G., et al., Init. Repts. DSDP, 38: Washington (U.S. Govt. Printing Office), 921-1098.

Schrader, J. J., and Gersonde, R., 1978. Diatoms and silicoflagellate. Utrecht Micropaleontol. Bull., 17:129-176.

Schuette, G., and Schrader, H. J., 1981. Diatom taphocoenoses in the coastal upwelling area off southwest Africa. Mar. Micropaleontol., 6:131-155.

Shackleton, N. J., and Cita, M. B., 1979. Oxygen and carbon isotope stratigraphy of benthic foraminifers at Site 397, detailed history of climatic change during the late Neogene. In von Rad, U., Ryan, W. B. F., et al., Init. Repts. DSDP, 47, Pt. 1: Washington (U.S. Govt. Printing Office), 433-445.

Shackleton, N. J., and Opdyke, N. D., 1973. Oxygen isotope and paleomagnetic stratigraphy of equatorial pacific Core V28-238, oxygen isotope temperatures and ice volumes on a $10^{5}$ year and $10^{6}$ year scale. Quat. Res. (N.Y.), 3:39-55.

1976. Oxygen-isotope and paleomagnetic stratigraphy of Pacific core V28-239, late Pliocene to latest Pliocene. Mem. Geol. Soc. Am., 145:449-464.

Sheshukova-Poretzkaya, V. S., 1962. Novie i redkie Bacillariophyta iz diatomovoi sviti Sakhalin. Uchenie Zapiski lgu, Ser. Biol. Nauk (Leningrad Univ.), 49:203-211.

1967. Neogenowye morskie diatomowye wodorosli sachalina i Kamuatki. Leningrak, pp. 1-432.

Simonsen, R., 1979. The diatom system: Ideas on phylogeny. Bacillaria 2. Germany (Braunschweig), J. Carmer, 9-79.

Simonsen, R., and Kanaya, T., 1961. Notes on the marine species of the diatom genus Denticula Kutz. Interl. Rev. Ges. Hydrobiol., 46(4):498-513.

Strelnikova, N. J., 1960. Diatomovye vodorosli i kremneveye zhgutikovye iz paleogenovyh otlozhenij Obsko-purskogo mezhdyrechya. Tr. VNIGRI, 158:33-45.

Tempère, J., and Peragallo, H., 1907-1915. Diatomees du Monde Entier, Edition 2, 30 fasc. Arcachon, Grez-sur-loing (S.-et-M.). Fasciculel, pp. $1-16,1907 ; 2-7$, pp. $17-112,1908 ; 8-12$, pp. 113-208, $1909 ; 13-16$, pp. $209-256,1910 ; 17-19$, pp. $257-304,1911 ; 20-23$, pp. 305-352, 1912; 24-28. pp. 353-448, 1913; 29-30, pp. 449-480, 1914; Tables, p. 1-68, 1915). (Exsicatta, slides 1-1000, 1915). 
Van Couvering, J. A., Berggren, W. A., Drake, R. F., Aguirre, F., and Curtin, G. H., 1976. The terminal Miocene event. Mar. Micropaleontol., 1:263-286.

Van Heurck, H., 1880-1896. Synopsis des Diatomees de Belgique. Atlas, pl. 1-30 (1880); pl. 31-77 (1881); pl. 78-103 (1882); pl. 104-132 (1883); pl. A,B,C (1885): (Ducaju et Cie), Anvers. Table Alphabetique, (J. F. Dieltjens), Anvers 120 pp. (1884). Texte, (Brouwors \& Co.). Anvers, 235 pp. (1885). 1896. A Treatise on the Diatomaceae, Trans. W. E. Baxter, 556 pp.

Vincent, E., Killingley, J., and Berger, W., 1980. The Magnetic Epoch 6 carbon shift: a change in the oceans ${ }^{13} \mathrm{C} /{ }^{12} \mathrm{C}$ ratio 6.2 million years ago. Mar. Micropaleontol., 5:185-203.

Wallich, G. C., 1860. On the siliceous organisms found in the digestive cavities of the Salpae, and their relation to the Flint nodules of the Chalk Formation. Trans. Microsc. Soc. London, 8:36-55.

Weaver, F., and Gombos, A., 1981. Southern high-latitude diatom biostratigraphy. In Warme, T. E., Douglas R. C., and Winterer, E. L. (Eds.), The Deep Sea Drilling Project: A Decade of Progress. Soc. Econ. Paleontol. Mineral Spec. Publ., 32: 445-470.

Wiseman, D., and Hendy, N., 1953. The significance and diatom content of deep-sea floor sample from the neighborhood of the greatest oceanic depth. Deep-Sea Res., 1:42-59.

Wornardt, W. W., 1974. Correlation of the neo-stratotype of the Messinian stage Capodarso and Pasquasia sections based on diatoms. In Simonsen R. (Ed.), Second Symposium on Recent \& Fossil Diatoms. Bei. 45 Nova Hedwegia, pp. 391-402.

Date of Acceptance: April 8, 1983

\section{APPENDIX \\ List of Flora}

Actinocyclus curvatulus Janisch 1878 in Schmidt et al. (1874-1959) pl. 57, fig. 31; Hustedt 1958, p. 129-130, pl. 8, fig. 81. (Plate 1, Fig. 9; Plate 2, Fig. 8).

Actinocyclus divisus (Grunow) Hustedt 1958, p. 129, pl. 8, fig. 81; synonym: Coscinodiscus divisus Grunow 1884, p. 31, pl. 4, fig. 16. (Plate 2, Fig. 7; Plate 9, Fig. 3).

Actinocyclus ehrenberg Ralfs in Pritchard 1861, p. 834; Hustedt 1929, p. 525, fig. 298. (Plate 7, Fig. 3).

Actinocyclus ellipticus Grunow in Van Heurck 1883, pl. 124, fig. 10; Schrader 1973, pl. 8, figs. 7-9, 12-14, 16, 17. (Plate 6, Figs. 4, 7)

Actinocyclus ellipticus var. elongatus (Grunow) Kolbe 1954, pl. 3, fig. 28.

Actinocyclus ingens Rattray 1890a s. ampl., p. 149, pl. 11, fig. 7; Baldauf and Barron 1980, pl. 1, figs. 1-4; Baldauf and Barron 1982, p. 68, pl. 1, figs. 6-10. (Plate 7, Figs. 1, 2, 5, and 7)

Remarks. Although a wide morphological variation of this species is observed, for the present paper, all specimens are recognized as $A$. ingens $\mathrm{s}$. ampl. One distinct variation includes specimens that are more robust, characterized by a distinct central hyaline area (see Plate 7, Figs. 5 and 7). The stratigraphic range of this morphological variation is equivalent to the ranges of other morphotypes. However, this variation seems to be restricted geographically to Atlantic Ocean sediments. (Plate 7, Figs. 1, 2, 5, 7).

Actinoptychus undulatus (Bailey) Ralfs in Pritchard 1861, p. 839, pl. 5, fig. 88; synonym: Actinocyclus undulatus Bailey 1842, pl. 2, fig. 11 . (Plate 3, Fig. 10).

Asterolampra marylandica Ehrenberg 1844a, p. 76, fig. 10; Hustedt 1930, p. 485-587, fig. 271. (Plate 1, Fig. 2).

Asteromphalus elegans Greville 1859, p. 161, pl. 7, fig. 6. (Plate 1, Fig. 3).

Asteromphalus hookeri Ehrenberg 1844a, fig. 3; Hustedt 1958, p. 127-128; pl. 8, figs. 88-90. (Plate 1, Figs. 1, 4).

Bacteriastrum hyalinum Lauder 1864, p. 8, pl. 3, fig. 7; Barron 1980b, pl. 2, fig. 10. (Plate 1, Fig. 5).

Brightwellia coronata (Brightwell) Ralfs in Pritchard 1861, p. 940; Fenner 1977, p. 512, pl. 2, fig. 5; pl. 3, fig. 1; synonym: Craspedodiscus coronatus Brightwell 1860, p. 95, pl. 5, fig. 6; Brightwellia pulchra Grunow in Van Heurck 1883, pl. 128, fig. 9.

Remarks. This species is very rare within Leg- 81 material. Specimens observed are generally poorly preserved but are assigned to this species based on having a spiral arrangement of the areolae within the "coronal ring" and having the areolae outside the "coronal ring" arranged in closely spaced linear radiating rows. See Fenner 1977 for a complete description. (Plate 13, Fig. 6).

Cocconeis vitrea Brun 1891, p. 19, pl. 18, fig. 2; Kanaya 1959, p. 110, fig. 6.

Coscinodiscus lewisianus Greville 1866 , p. 78 , pl. 8, figs. 8-10; Schrader 1973, p. 703 , pl. 8, figs. 1-6, 10, 15. Comments: Very few specimens of this species were observed in Hole 555. (Plate 8, Figs. $7,8)$.

Coscinodiscus marginatus Ehrenberg 1841a, p. 142; Ehrenberg 1854, pl. 18, fig. 44; Hustedt 1930, p. 416, fig. 223. (Plate 8, Figs. 1-3) Coscinodiscus nodulifer Schmidt 1878 in Schmidt et al. (1874-1959) Kanaya 1971, pl. 40.3, figs. 1-4. (Plate 3, Fig. 16; Plate 8, Fig. 6). Coscinodiscus nodulifer var. cyclopus Jousé 1977, pl. 45, figs. 11, 15; pl. 48 , figs. $1-6$, pl. 52 , figs. $6-7$, pl. 77 , fig. 17 , pl. 78 , figs. $1-4$, pl. 79, fig. 16; Barron 1980b, pl. 4, fig. 3. (Plate 3, Figs. 17, 18).

Coscinodiscus oblongus Greville 1866, p. 4, pl. 1, figs. 9, 10; Hustedt 1939 , p. $426-427$, fig. 229.

Coscinodiscus obscurus Schmidt 1878, in Schmidt et al. (1874-1959) pl. 61, fig. 16; Rattray 1890 b, p. 513 , fig. 65 ; Hustedt 1928 , p. 418 , pl. 224.

Coscinodiscus oculus-iridis Ehrenberg 1839, p. 147; Ehrenberg 1854, pl. 18 , fig. 42 , pl. 19 , fig. 2 .

Coscinodiscus plicatus Grunow 1878 in Schmidt et al. (1874-1959), pl. 59, fig. 1; Grunow 1884, p. 73, pl. 3c, fig. 10; Schrader 1973, p. 703 , pl. 6 , fig. 23.

Coscinodiscus praenitidus Fenner in Schrader and Fenner 1976, p. 972, pl. 15, fig. 7, pl. 17, fig. 8. (Plate 10, Fig. 4).

Coscinodiscus praeyabei Schrader 1973, pl. 6, fig. 16, pl. 7, figs. 17-20, 22, 23; Baldauf and Barron, 1982, pl. 3, fig. 4.

Coscinodiscus radiatus Ehrenberg 1839, p. 148, pl. 3, figs. la-c; Hustedt 1930, p. 420 , fig. 225.

Coscinodiscus stellaris Roper 1858, p. 21, pl. 3, fig. 3; Hustedt 1930 , p. 396-398, fig. 207; Schrader 1973, pl. 26, fig. 7.

Coscinodiscus tabularis Grunow 1884, p. 86; Rattray 1890 b, p. 583 , fig. 135; Baldauf and Barron 1982, p. 69, pl. 4, figs. 6, 7. (Plate 3, Fig. 11).

Coscinodiscus yabei Kanaya 1959, p. 86, pl. 5, figs. 6-9; Schrader 1973, p. 704, pl. 6, figs. 1-6. (Plate 2, Fig. 9; Plate 8, Fig. 5).

Coscinodiscus sp. 1, (Plate 8, Fig. 4).

Craspedodiscus coscinodiscus Ehrenberg 1844b, p. 266; Ehrenberg 1854 , pl. 18, fig. 10; Rattray 1890 b, p. 600 ; Kanaya 1971 , p. 555 , pl. 40.4, figs. 1-3. (Plate 9, Fig. 6).

Cussia paleacea (Grunow) Schrader 1974b, p. 543, pl. 1, figs. 11-14, synonym: Stoschia paleacea Grunow in Van Heurck 1883, pl. 128, fig. 6 .

Denticulopsis dimorpha (Schrader) Simonsen 1979, p. 64. Synonym: Denticula dimorpha Schrader, 1973, p. 704, pl. 1, figs. 37-46; Barron 1980a, pl. 1, fig. 21.

Denticulopsis hustedtii (Simonsen and Kanaya) Simonsen 1979, p. 64; Baldauf and Barron 1982, pl. 7, figs. 7, 8. synonym: Denticula hustedtii Simonsen and Kanaya 1961, p. 501, pl. 1, figs. 19-25, pl. 2, figs. 36-47; Schrader 1973, p. 704, pl. 2, figs. 28-34, 36-47. (Plate 3, Figs. 3-5).

Denticulopsis hyalina (Schrader) Simonsen 1979, p. 64; Baldauf and Barron 1982, pl. 7, figs. 2, 4; synonym: Denticula hyalina Schrader 1973, p. 704, pl. 1, figs. 12-22. (Plate 3, Figs. 2, 6-8).

Denticulopsis nicobarica (Grunow) Simonsen 1979, p. 65; Baldauf and Barron 1982, pl. 7, fig. 6; synonym: Denticula nicobarica Grunow 1868 , p. 97, pl. 1a, fig. 5. (Plate 3, Fig. 9).

Denticulopsis praedimorpha (Akiba, 1979) Barron, 1981, p. 529, pl. 4, figs. 8-10; synonym: Denticula praedimorpha (Akiba, 1979) Barron 1980 a, pl. 1, figs. 18-20.

Denticulopsis punctata (Schrader) Simonsen 1979, p. 65; Baldauf and Barron 1982, pl. 7, fig. 7. synonym: Denticula punctata Schrader 1973, p. 705, pl. 1, figs. 25-30, pl. 3, figs. 16, 17.

Denticulopsis puncatata var. hustedtii (Schrader) Simonsen 1979; Barron 1981, pl. 4, fig. 1; synonym: Denticula punctata var. hustedtii Schrader 1973, p. 705, pl. 1, figs. 23, 24. (Plate 3, Figs. 1, 15).

Denticulopsis seminae (Simonsen and Kanaya) Simonsen, 1979; Barron 1981, p. 529. synonym: Denticula seminae Simonsen and Kanaya 1961, p. 503, pl. 1, figs. 26-30; Barron 1980a, pl. 1, fig. 1. (Plate 3, Figs. 12-14). 
Denticulopsis seminae var. fossilis (Koizumi) Simonsen 1979; synonym: Denticula seminae var. fossilis Schrader, Koizumi 1975b, pl. 1, figs. 3, 4.

Ethmodiscus rex (Wallich) Hendey in Wiseman and Hendey 1953, p. 51 , pl. 1, fig. 2; synonym: Coscinodiscus rex Wallich in Rattray 1890 b, p. 568 , fig. 120 .

Goniothectum odontella Ehrenberg 1844a, p. 82; Gombos and Ciesielski (1983), pl. 22, fig. 9. (Plate 11, Fig. 3).

Hemidiscus cuneiformis Wallich 1860, p. 42, pl. 2, figs. 3, 4; Barron 1980b, pl. 1, figs. 9, 10. (Plate 1, Figs. 6, 7).

Hemiaulus polymorphus Grunow 1884, p. 66; Fenner 1977, p. 522, pl. 21, fig. 11, pl. 23, figs. 10,11 , pl. 22, fig. 13.

Hemiaulus polycistinorum Ehrenberg 1854, pl. 36, figs. 43a, b; Fenner 1977 , p. 521, pl. 21, figs. 13, 14; pl. 22, figs. 4, 5, 7-10, pl. 23, figs. 1-4. (Plate 12, Figs. 5, 11).

Hemiaulus sp. 1. (Plate 13, Fig. 1).

Hemiaulus sp. 2. (Plate 12, Fig. 10).

Hyalodiscus dentatus Korotkevicz 1964, p. 104, pl. 1, figs. 1-4.

Macrora stella (Azpeitia) Hanna 1932, p. 196, pl. 12, fig. 7; synonym: Pyxidicula stella Azpeitia 1911, p. 150-152, pl. 1, fig. 1.

Remarks. This species is not a diatom but is useful as a good guide fossil for middle Miocene sediments (see Schrader 1973, and Hanna 1932). (Plate 5, Fig. 9).

Mediaria splendida Sheshukova-Poretzkaya 1962, p. 210, pl. 2, fig. 5; Baldauf and Barron 1982, pl. 7, fig. 15.

Melosira cf. architecturalis Brun 1892 in Schmidt et al. (1874-1959), pl. 177, figs. 45-50; Schrader and Fenner 1976, p. 989, pl. 14, fig. 13 ; pl. 29 , fig. 7,8 ; ; pl. 35 , figs. $1-4$.

Remarks. Placement of observed specimens into this taxa is only tentative due to the quality of preservation of the specimens. (Plate 10, Fig. 5).

Melosira clavigera Grunow in Van Heurck 1882, pl. 91, fig. 1;

Melosira sulcata (Ehrenberg) Kutzing 1844, p. 55, pl. 2, fig. 7; synonym: Gallionolla sulcata Ehrenberg 1838, p. 170, pl. 21, fig. 5. (Plate 6, Fig. 6).

Navicula lyra Ehrenberg 1841b, p. 419, pl. 1, fig. 1; Hustedt 1964, p. 453-464, figs. 1516-1523.

Navicula scutellum (O'Mears) O'Mears 1876, p. 396, pl. 33, fig. 14; synonym: Pinnularia scutellum O'Mears 1869, p. 151, pl. 2, fig. 5.

Navicula sp. 1. (Plate 6, Fig. 9).

Nitzschia cf. cylindrica Burckle 1972, p. 239-240. pl. 2, figs. 1-6; Schrader 1973, p. 707, pl. 5, figs. 27, 32, 33.

Remarks. Observed specimens of this species have wide morphological variation. Two morphologically distinct end members exist; those that are linear with broadly rounded apices. (Plate 4, Fig. 13) and those which have slightly less rounded apices, and a mid region which is slightly wider than the apices (Plate 4, Fig. 18). Both forms have the same stratigraphic range and until further taxonomic work can be completed, are considered to be variations of the same species. (Plate 4, Figs. 13, 18).

Nitzschia fossilis (Frenguelli) Kanaya in Kanaya and Koizumi 1970; Schrader 1974a, p. 914, pl. 4, figs. 9-11, 24, 25; Barron 1980a, pl. 2, figs. 3, 4. (Plate 4, Figs. 8, 10, 11, 14, 15, 16?, 17?).

Nitzschia jouseae Burckle 1972, p. 240. pl. 2, figs. 17-20; Schrader 1973, pl. 4, figs. 20, 21, 22-23 (?). (Plate 6, Figs. 13, 14).

Nitzschia marina Grunow in Cleve and Grunow 1880, p. 70; Grunow in Van Heurck 1881, pl. 57, figs. 26-27; Schrader 1973, pl. 4, figs. 17-19; Schrader 1974a, pl. 5, figs. 1, 2, 5, 14(?).

Remarks. $N$. marina is characterized by having parallel sides and slightly pointed apices (Plate 5, Figs. 1, 2). However, wide morphological variation does occur, with forms seeming to blend into a intermediate Nitzschia fossilis-Nitzschia reinholdii category (see Plate 4, Figs. 1-4). (Plate 4, Figs. 1-4; Plate 5, Figs. 1-3).

Nitzschia miocenica Burckle 1972, p. 240-241, pl. 2, figs. 10-15; Barron 1980 a, p. 672 , pl. 2, fig. 8; pl. 3, figs. 3, 4 .

Remarks. The specimen found on Plate 6, Fig. 16 corresponds to Nitzschia sp. aff. N. miocenica Burckle of Barron 1980a, pl. 3, fig. 4. (Plate 6, Figs. 15, 16).

Nitzschia panduriformis Gregory 1857, p. 529, fig. 57; Fenner 1977, p. 525, pl. 32, figs. 27-29. (Plate 5, Fig. 8).

Nitzschia porteri Frenguelli 1949, p. 116, pl. 1 figs. 33-34; Schrader 1973 , p. 707 , pl. 5 , figs. $35,36,43,44,39-41$.

Nitzschia praereinholdii Schrader 1973, p. 708, pl. 5, figs. 20, 23, 26; Barron 1981, pl. 4, fig. 16.
Nitzschia reinholdii Kanaya and Koizumi 1970; Schrader 1973, p. 708, pl. 4, fig. 12-16, pl. 5, figs. 1-9; Barron 1981, pl. 4, fig. 15. (Plate 4, Figs. 5-7; Plate 5, Fig. 4).

Nitzschia sp. 1. (Plate 4, Fig. 12).

Nitzschia sp. 2. (Plate 6, Fig. 12).

Opephora sp. 1. (Plate 4, Fig. 9).

Podosira bella Strelnikova 1960, p. 34. (Plte 10, Fig. 6).

Podosira glacialis (Grunow) Jorgensen 1905, p. 97, pl. 6, fig. 7; synonym: Podosira hormeides var. glacialis Grunow 1884, p. 108, pl. 5e, fig. 32.

Pseudoeunotia doliolus (Wallich) Grunow in Van Heurck 1881, pl. 35, fig. 22; Schrader 1973, p. 708, pl. 4, figs. 1-8; synonym: Synedra doliolus Wallich 1860 , p. 48 , pl. 2, fig. 19. (Plate 5, Figs. 5-7).

Pterotheca aculeifera (Grunow) Van Heurck 1896, p. 430, fig. 151; Fenner 1977, p. 526, pl. 17, figs. 8-21; synonym: Pyxilla aculeifera Grunow in Van Heurck 1882, pl. 83, figs. 13, 14. (Plate 10, Figs. $11,12)$.

Pterotheca danica (Grunow) Forti 1909, p. 13; synonym: Stephanogonia danica Grunow 1866, p. 146. (Plate 12, Figs. 8, 9).

Pterotheca spada Tempère et Brun, in Brun and Tèmpere 1889, p. 50, pl. 1, fig. 7; Schrader and Fenner 1976, p. 994, pl. 41, figs. 4, 5, $12,13$.

Pyrgupyxis prolongata (Brun) Hendey (1969); Brun 1890-1893, p. 176, pl. 2, fig. 7; Fenner 1977, p. 528, pl. 19, fig. 8.

Pyxilla renticulata Grove and Sturt 1887, p. 145, pl. 13, fig. 50. (Plate 10, Fig. 9).

Rhaphoneis amphiceros Ehrenberg 1844a, p. 87; Hustedt 1959, p. 174, figs. 680-681; Schrader 1973, p. 708-709, pl. 25, figs. 2, 3.

Rhaphoneis surirella (Ehrenberg) Grunow in Cleve and Moller 1878, p. 154-155; Hustedt 1959, p. 173-174, fig. 679; Schrader 1973, p. 709, pl. 25, figs. 4, 6; synonym: Zygoceros surirella Ehrenberg 1839 , p. 160 , pl. 4 , fig. 12 .

Rhizosolenia barboi (Brun) Tempère and Peragallo 1908, p. 26, No. 47; Schrader 1973, p. 709, pl. 24, figs. 4, 7; synonym: Pyxilla barboi Brun 1894, p. 87, pl. 5, figs. 16, 17 and 23. (Plate 1, Fig. 12).

Rhizosolenia bergonii Peragallo 1892, p. 110, pl. 15, fig. 5; Schrader 1973 , p. 709 , pl. 9 , figs. $1-5,7,8,10,12,22,23$; pl. 10, figs. 24 , 29. (Plate 2, Fig. 5).

Rhizosolenia curvirostris Jousé 1959, p. 48, pl. 2, fig. 17; Donahue 1970, p. 135-136, fig. 6; Schrader 1973, p. 709, pl. 24, figs. 5, 6, 8, 9.

Remarks. Specimens observed of this species differ in the amount of curvature and in the robustness of the lateral spine. (compare Plate 2, Fig. 6 with Plate 1, Fig. 10). (Plate 1, Fig. 10; Plate 2, Fig. $6)$.

Rhizosolenia hebatata Bailey 1856, p. 5, pl. 1, figs. 18, 19.

Rhizosolenia hebatata forma hiemalis Gran 1904, p. 527, pl. 27, fig. 9; Schrader 1973, pl. 9, figs. 11, 13-17, 19-21, 24, 25. (Plate 2, Figs. 1, 2, 4).

Rhizosolenia interposita Hajós 1976, p. 827, pl. 21, fig. 8.

Rhizosolenia miocenica Schrader 1973, p. 707, pl. 10, figs. 2-6, 9-11; Barron 1980a, pl. 4, fig. 8; Schrader and Fenner 1976, p. 996, pl. 9 , figs. $5,11,13,14$.

Rhizosolenia praebarboi Schrader 1973, p. 709, pl. 24, figs. 1-3; Barron 1980a, pl. 2, fig. 18. (Plate 1, Fig. 11).

Rhizosolenia praebergonii Muchina 1965; Burckle 1972, pl. 1, fig. 1; Koizumi 1968, p. 217, pl. 34, figs. 20, 21; Schrader 1973, pl. 10, fig. 7 , pl. 9, fig. 6 .

Remarks. This species is very rare within Leg 81 material. Plate 2, Fig. 3).

Rhizosolenia styliformis Brightwell 1858, p. 95, pl. 5, figs. 5a, b and d; Hustedt 1930, p. 584-588, figs. 333-335; Schrader 1973, pl. 10, figs $1,20,21,18,19$; pl. 9, fig. 9(?).

Rocella gelida (Mann) Bukry 1978b, p. 788, pl. 5, figs. 1-13; Gombos and Ciesielski (1983), pl. 6, figs. 1-6, pl. 26, fig. 1. (Plate 9, Figs. $7,8)$.

Roperia tesselata (Roper) Grunow in Van Heurck 1883, pl. 118, figs. 6, 7; Barron 1980b, pl. 3, figs. 8, 10. (Plate 6, Figs. 5, 8).

Rouxia californica Peragallo in Tempère and Peragallo 1910, p. 245, No. 468-469; Hanna 1930, p. 186-188, pl. 14, figs. 6-7; Schrader 1973, p. 710, pl. 3, figs. 18-20, 26.

Sceptroneis gemmata Grunow 1886, p. 146. (Plate 10, Fig. 10).

Stephanopyxis eocenicus Hajós 1976, p. 824, pl. 4, figs. 3, 4. 
Stephanopyxis grunowii Grove and Sturt 1887 in Schmidt et al. (18741959), pl. 130, figs. 1-4; Fenner 1977, p. 532, pl. 12, figs. 10, 13. (Plate 10, Fig. 2).

Stephanopyxis cf. raeana (Castracane) De Toni 1894, p. 1146; synonym: Systephania raeana Castracane 1886, p. 151, pl. 9, fig. 11. (Plate 12, Fig. 2).

Stephanopyxis turris (Greville et Arnott) Ralfs 1861, p. 826, pl. 5, fig. 74; Fenner 1977, p. 532, pl. 12, figs. 8, 9; synonym: Cresswellia turris Greville et Arnott 1857, p. 538. (Plate 6, Fig. 10).

Stepanopyxis turris var. cylindrus Grunow 1884, p. 87, fig. 35. (Plate 10, Figs. 3, 13).

Stephanopyxis sp. 1. (Plate 10, Fig. 1).

Stephanopyxis sp. 2. (Plate 11, Fig. 5).

Stephanopyxis sp. 3. (Plate 17, Fig. 3).

Stictodiscus angulatus Grunow et Moller 1868 in Kitton 1871, p. 168. (Plate 10, Fig. 8).

Synedra jouseae Sheshukova-Poretzkaya 1962, p. 208, fig. 4; Schrader 1973, pl. 23, figs. 21-23, 25, 28. (Plate 6, Fig. 1).

Synedra ulna (Nitzsch) Ehrenberg 1838, p. 211, pl. 17, fig. 1; synonym: Bacillaria ulna Nitzsch 1817, p. 99, pl. 5 .

Thalassionema nitzschiodes (Grunow) Van Heurck 1896, p. 319, fig. 75 ; Schrader 1973, pl. 23, figs. 2, 6, 8, 9, 10, 26, 29, 34, 12-13. (Plate 6, Figs. 2, 3).

Thalassionema sp. 1. (Plate 6, Fig. 1).

Thalassiosira convexa Muchina 1965; Schrader 1974a, pl. 2, figs. 1-5, 10-13; Barron 1980b, pl. 8, fig. 1. (Plate 5, Fig. 10; Plate 7, Figs. $4,8)$.

Thalassiosira convexa var. aspinosa Schrader 1974a, pl. 2, figs. 8, 9, 13-21; synonym: Thalassiosira convexa Koizumi 1975a, pl. 4, figs. 15-18. (Plate 7, Figs. 6, 9).

Thalassiosira eccentrica Cleve 1904, p. 216; Sheshukova-Poretzkaya 1967 , p. 141-142, pl. 14, fig. 4; Schrader 1973, pl. 25, fig. 17; pl. 16, figs. 5, 6. (Plate 9, Figs. 1, 4).

Thalassiosira jacksonii Koizumi et Barron in Koizumi 1980, p. 396, pl. 1, figs. 11-14; Barron 1980a, pl. 6, figs. 2, 6 1d?; synonym: Thalassiosira sp. b Schrader and Fenner 1976, pl, 17, figs. 5, 10. (Plate 5, Fig. 11).
Thalassiosira leptopus (Grunow) Hasle and Fryxell 1977, figs. 1-14, 94-96; synonym: Coscinodiscus lineatus Ehrenberg; Reinhold 1937, pl. 11, fig. 7. (Plate 1, Fig. 8; Plate 9, Fig. 5).

Thalassiosira miocenica Schrader 1974a, p. 916, pl. 22, figs. 1-5, 11-13; Barron 1980a, pl. 3, fig. 6; synonym: Thalassiosira usatchevii Jousé in Burckle 1972, p. 228.

Thalassiosira oestrupii (Ostenfeld) Proshkina-Lavrenko 1949; Hasle 1960, p. 8, pl. 1, figs. 5, 7, and 1; Schrader 1974a, pl. 1, figs. 3-11, 13-16, 19, 20; pl. 14, fig. 5; synonym: Coscinosira oestrupii Ostenfeld 1900 , p. 52. (Plate 2, Figs. 11, 12).

Thalassiosira praeconvexa Burckle 1972, p. 242-243, pl. 2, figs. 7-9; Schrader 1973, pl. 11, figs. 10-15.

Thalassiosira sp. 1. (Plate 2, Fig. 10).

Thalassiosira sp. 2. (Plate 2, Fig. 13).

Thalassiosira sp. 3. (Plate 9, Fig. 2).

Thalassiothrix longissima Cleve et Grunow in Cleve and Moller 1878, No. 118, No. 207; Schrader 1973, pl. 23, figs. 7, 17, 18.

Trinacria pileolus (Ehrenberg) Grunow 1884, p. 68, pl. B, figs. 59, 60; Hustedt 1930 , p. 885 , fig. 529; Fenner 1977, p. 536, pl. 24, figs. 16-17; synonym: Triceratium pileolus Ehrenberg 1844c, p. 205.

Trinacria simulacrum Grove and Sturt 1887, p. 144, pl. 13, fig. 46; Fenner 1977, p. 536, pl. 29, fig. 2, pl. 31, fig. 2. (Plate 11, Fig. 10; Plate 13, Fig. 11).

Trinacria sp. 1. (Plate 10, Fig. 7).

Trinacria sp. 2. (Plate 12, Fig. 7).

Xanthiopyxis ovalis Lohman 1938, p. 91, pl. 20, fig. 6; pl. 22, fig. 12.

Genus and species indet. 1 (Plate 11, Fig. 1).

Genus and species indet. 2 (Plate 11, Fig. 6).

Genus and species indet. 3 (Plate 11, Fig. 8).

Genus and species indet. 4 (Plate 11, Fig. 9).

Genus and species indet. 5 (Plate 12, Fig. 1).

Genus and species indet. 6 (Plate 12, Fig. 4).

Genus and species indet. 7 (Plate 12, Fig. 6).

Genus and species indet. 8 (Plate 13, Figs. 5, 7).

Genus and species indet. 9 (Plate 13, Fig. 8). 

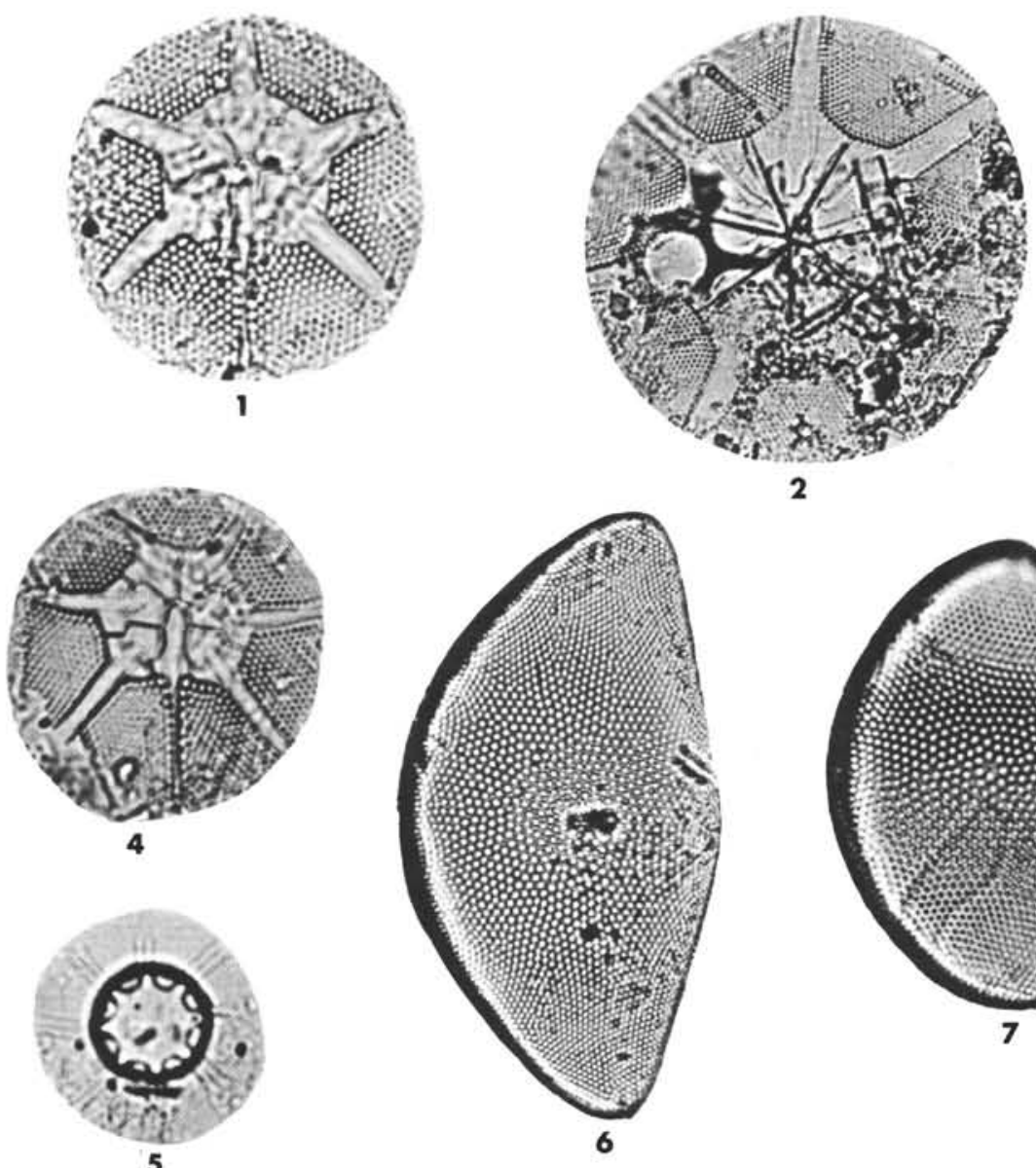

2
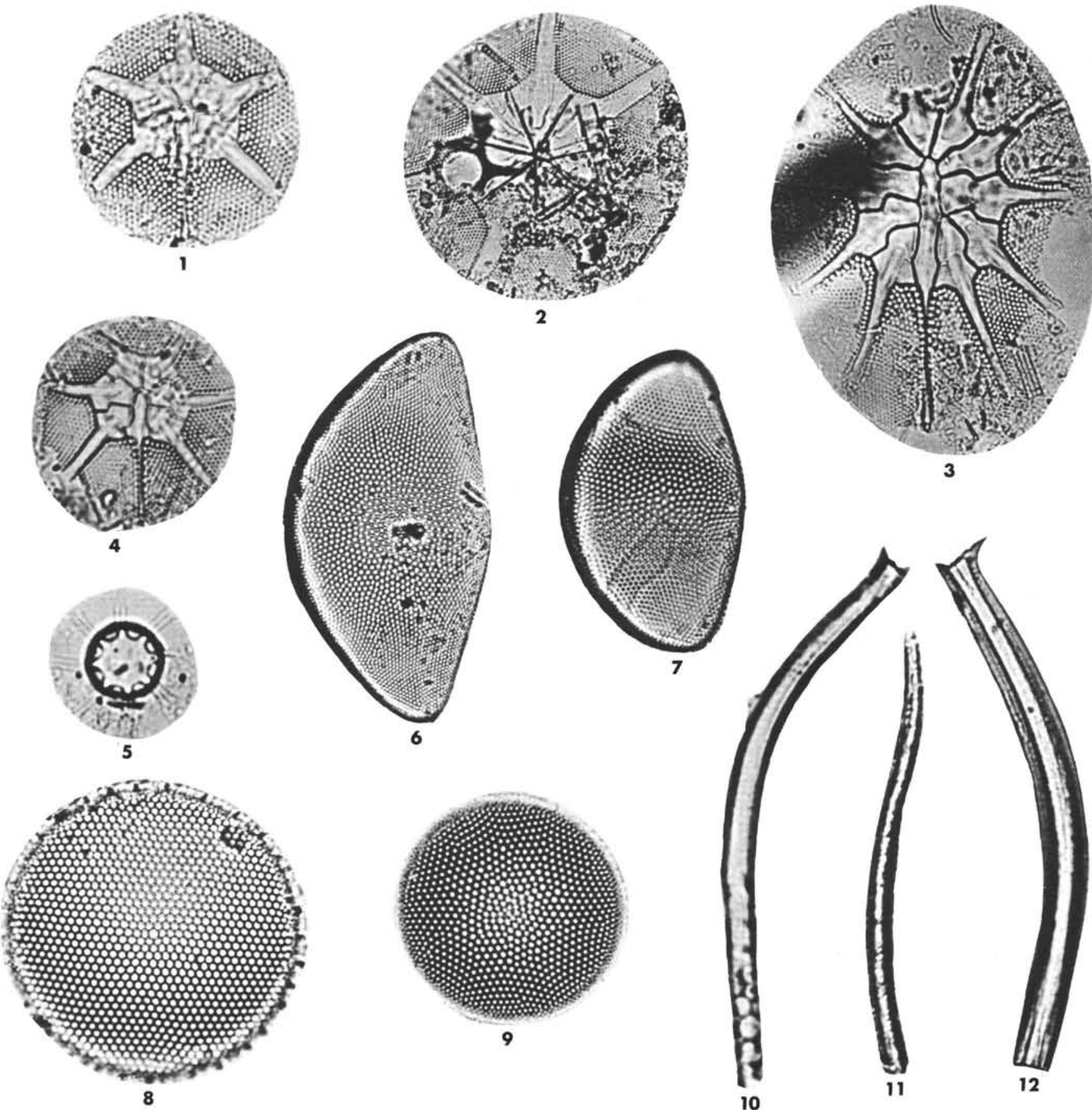

Plate 1. 1. Asteromphalus hookeri Ehrenberg. Sample 552A-16-1, 130-131 cm, length $48 \mu \mathrm{m}$. 2. Asterolampra marylandica Ehrenberg. Sample 555-19-1, 76-77 cm, length $67 \mu \mathrm{m}$. 3. Asteromphalus elegans Greville. Sample 552A-9-3, 93-94 cm, length $88 \mu \mathrm{m}$. 4. Asteromphalus hookeri Ehrenberg. Sample 552A-15-3, 100-101 cm, length $39 \mu \mathrm{m}$. 5. Bacteriastrum hyalinum Lander. Sample 552A-10-2, 130-131 cm, length 10 $\mu \mathrm{m}$. 6, 7. Hemidiscus cuneiformis Wall; (6) Sample 552A-15-3, 100-101 cm, length $76 \mu \mathrm{m}$; (7) Sample 552A-15-3, 100-101 cm, length $56 \mu \mathrm{m}$. 8. Thalassiosira leptopus (Grunow) Hasle and Fryxell. Sample 552A-16-1, 130-131 cm, length $53 \mu \mathrm{m}$. 9. Actinocyclus curvatulus Janisch. Sample 552A-9-3, 93-94 cm, length $42 \mu \mathrm{m}$. 10. Rhizosolenia curvirostris Jousé. Sample 552A-2-2, $90 \mathrm{~cm}$, length $88 \mu \mathrm{m}$. 11. Rhizosolenia praebarboi Schrader. Sample 552A-21-2, 121-122 cm, length $56 \mu \mathrm{m}$. 12. Rhizosolenia barboi Brun. Sample 552A-15-3, $100-103 \mathrm{~cm}$, length $67 \mu \mathrm{m}$. 

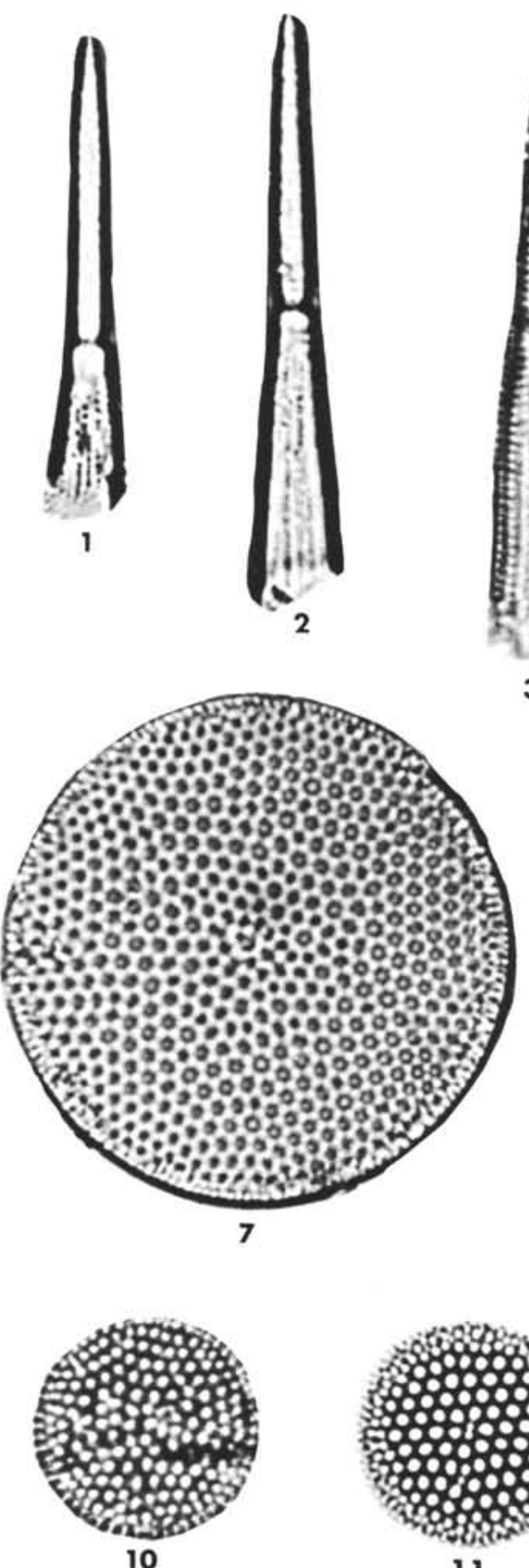

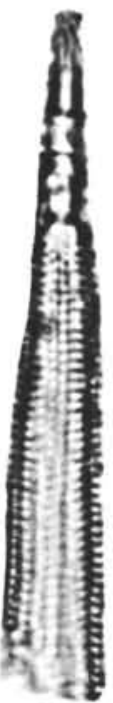

3
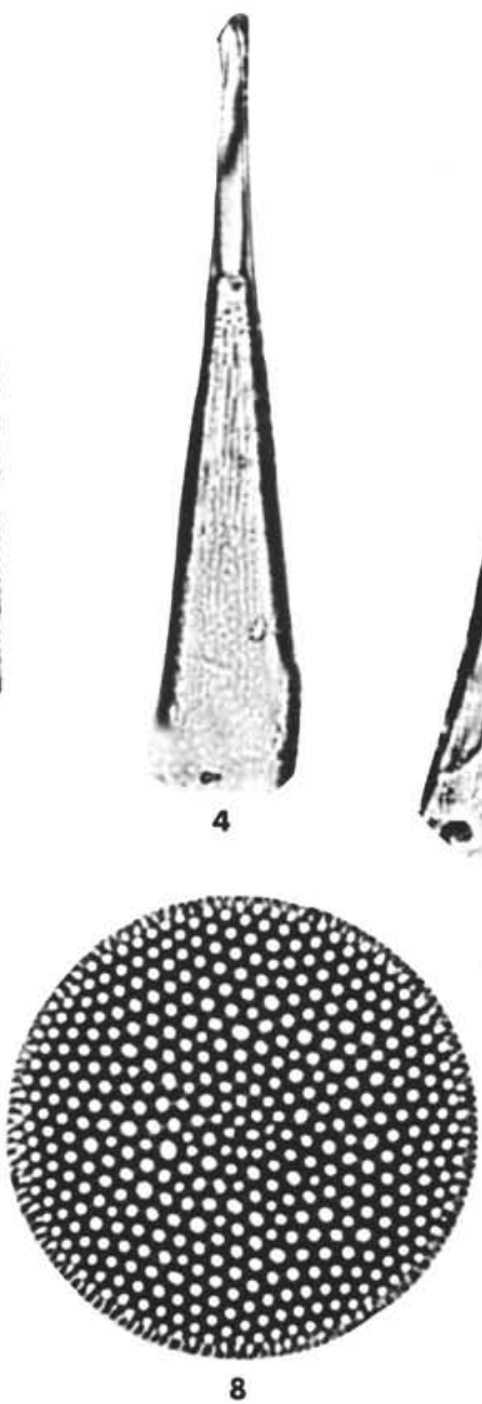
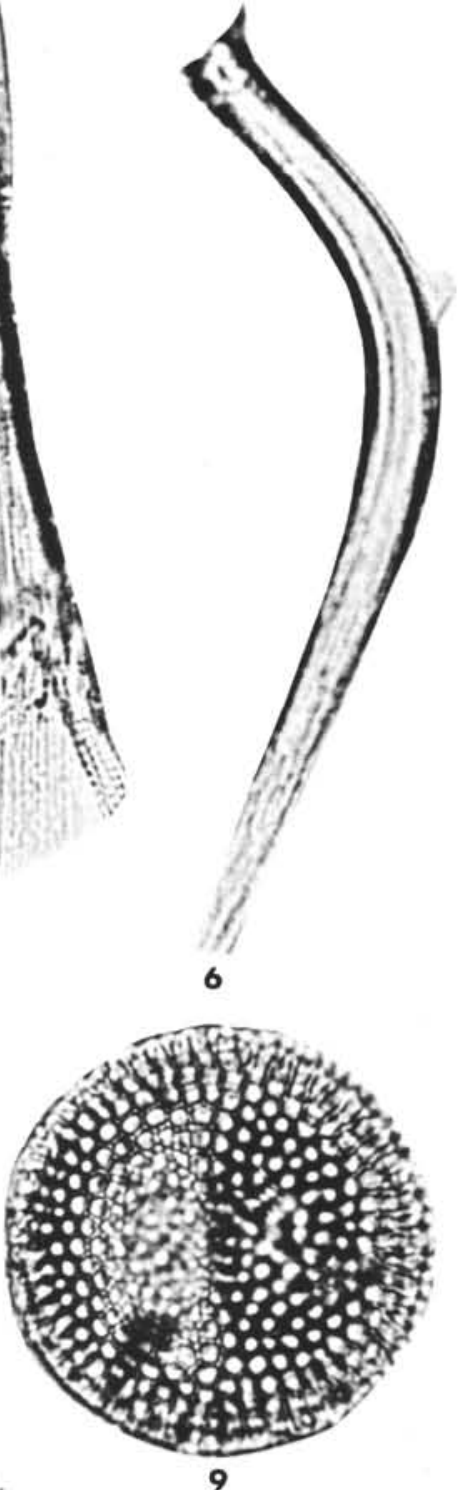

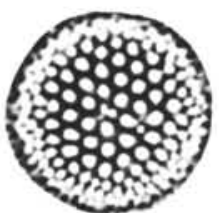

12

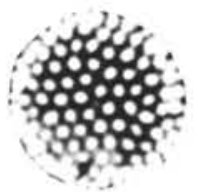

13

Plate 2. 1, 2, 4. Rhixosolenia hebatata forma hiemalis Grun; (1) Sample 552A-15-3, 100-101 cm, length 36 $\mu \mathrm{m}$; (2) Sample 552A-15-3, 100-101 $\mathrm{cm}$, length $48 \mu \mathrm{m}$; (4) Sample 552A-16-1, 130-131, $76 \mu \mathrm{m}$. 3. Rhizosolenia praebergonii Schrader. Sample $552 \mathrm{~A}-10-1,70 \mathrm{~cm}$, length $65 \mu \mathrm{m}$. 5. Rhizosolenia bergonii Peragallo. Sample 552A-9-3, 33-34 cm, length $83 \mu \mathrm{m}$. 6. Rhizosolenia curvirostris Jousé. Sample 552A-2-1, $90 \mathrm{~cm}$, length $70 \mu \mathrm{m}$. 7. Actinocyclus divisus (Grunow) Hustedt. Sample 552A-16-1, 130-131 cm, length $65 \mu$. 8. Actinocyclus curvatulus Janisch. Sample 552A-15-3, 100-101 cm, length $33 \mu \mathrm{m}$. 9. Coscinidiscus yabei Kanaya. Sample 555-19-1, 76-77 cm, length $39 \mu \mathrm{m}$. 10. Thalassiosira sp. 1. Sample 552A-16-1, 130-131 cm, length $14 \mu \mathrm{m}$. 11, 12. Thalassiosira oestrupii (Ostenfeld) Proskina-Lavrenko; (11) Sample 552A-9-3, 33-34 cm, length $17 \mu \mathrm{m}$; (12) Sample 552A-9-3, 33-34 cm, length $8 \mu \mathrm{m}$. 13. Thalassiosira sp. 2. Sample 553A-1,CC, length $8 \mu \mathrm{m}$. 

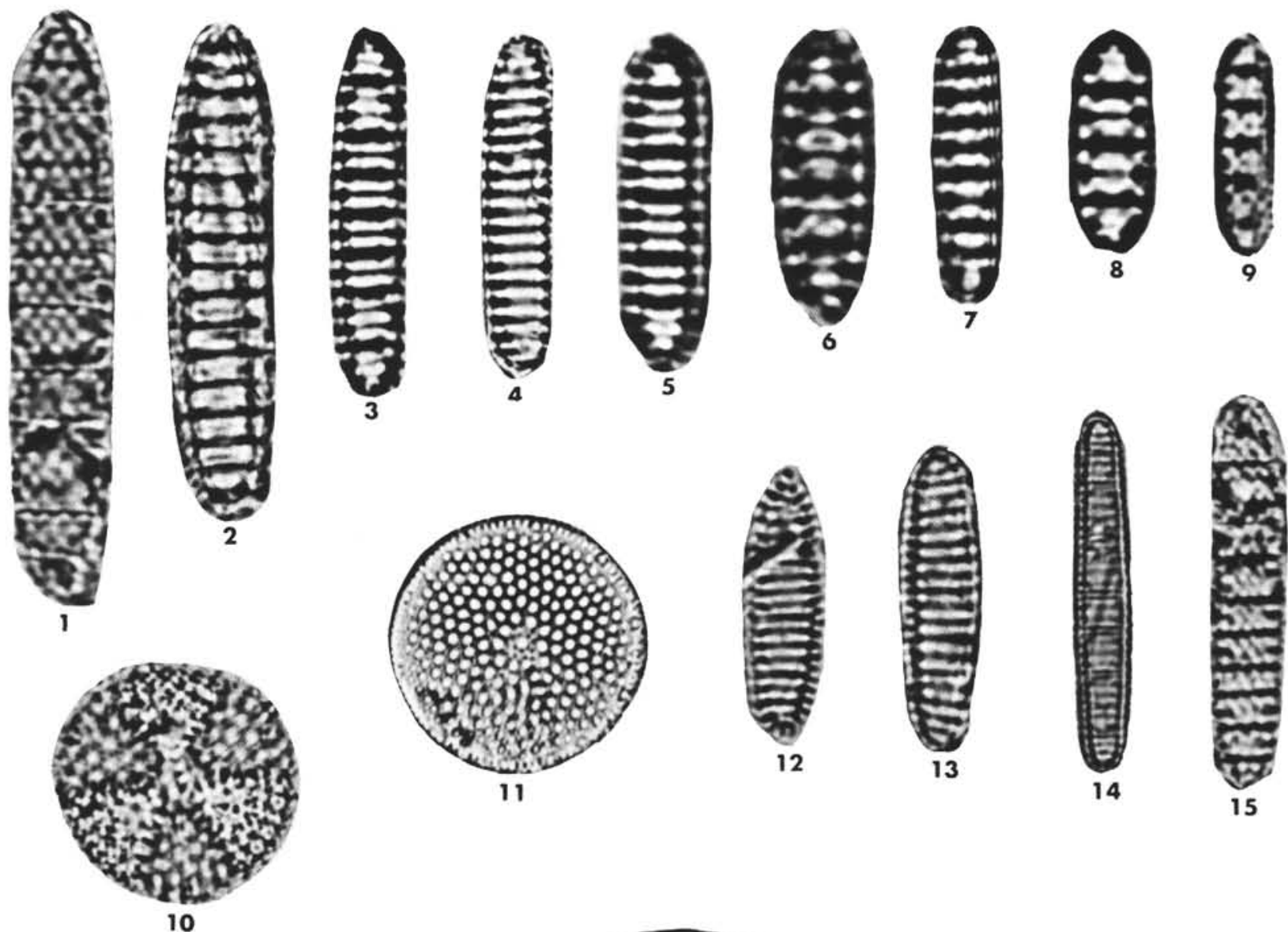

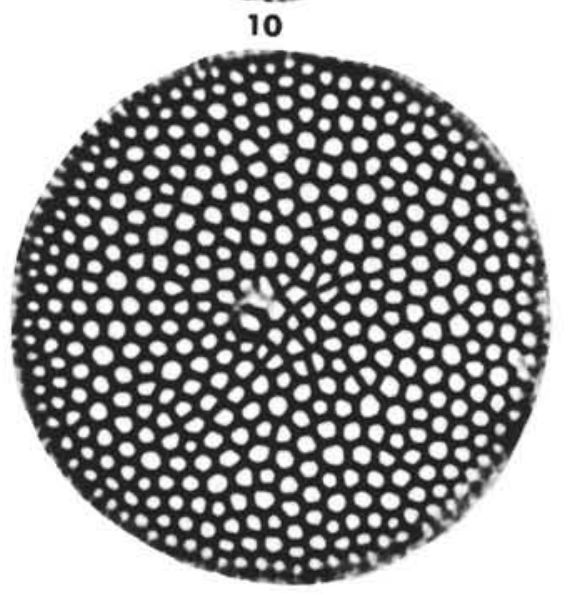

16
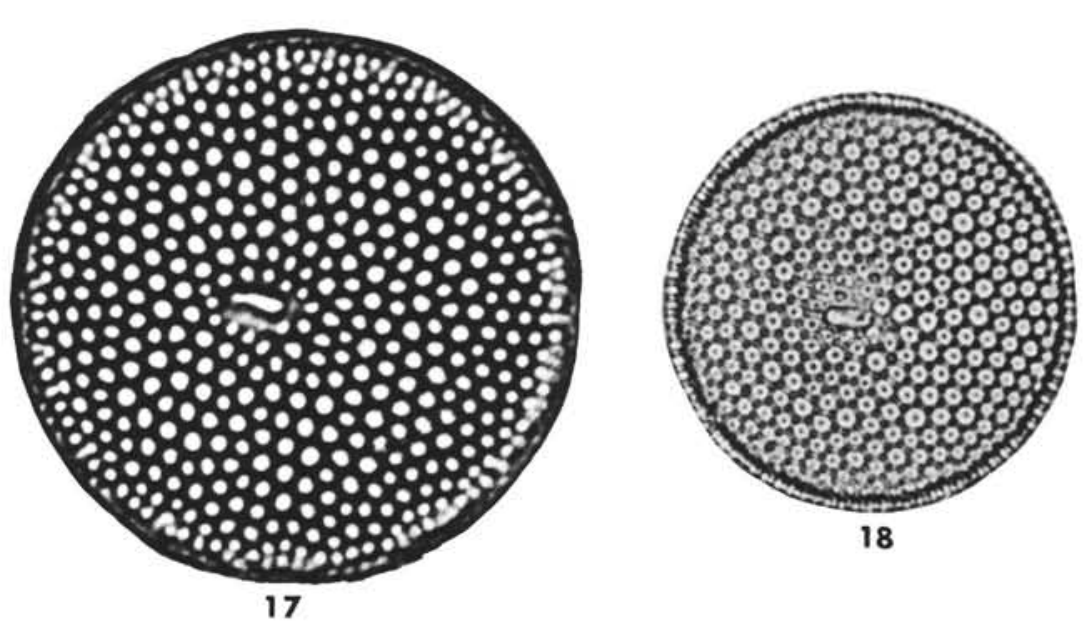

17

Plate 3. 1, 15. Denticulopsis punctata var. hustedtii (Schrader) Simonsen; (1) Sample 555-12-2, 62-63 cm, length $27 \mu \mathrm{m}$; (15) Sample 555-12-2, 62$63 \mathrm{~cm}$, length $39 \mu \mathrm{m}, 2,6,7,8$. Denticulopsis hyalina (Schrader) Simonsen; (2) Sample 552A-29, CC length 37 $\mu \mathrm{m} ;$ (6) Sample 555-19-1, 76-77 $\mathrm{cm}$, length $33 \mu \mathrm{m}$; (7) Sample 555-19-1, 76-77 cm, length $21 \mu \mathrm{m}$; (8) Sample 555-19-1, 76-77 cm, length $14 \mu \mathrm{m}$. 3, 4, 5. Denticulopsis hustedtii (Simonsen and Kanaya) Simonsen; (3) Sample 555-13,CC, length $33 \mu \mathrm{m}$; (4) Sample 555-19-1, 76-77 cm, length 33 $\mu \mathrm{m}$. (5) Sample 555-12-2, 62$63 \mathrm{~cm}$, length $28 \mu \mathrm{m}$. 9. Denticulopsis nicobarica (Grunow) Simonsen. Sample 555-21-2, 121-122 cm, length $10 \mu \mathrm{m}$. 10. Actinoptychus undulatus (Bailey) Ralfs. Sample 552A-29,CC, length $17 \mu \mathrm{m}$. 11. Coscinodiscus tabularis Grunow. Sample 555-19-1, 76-77 cm, length $21 \mu \mathrm{m}$. 12-14. Denticulopsis seminae (Simonsen and Kanaya) Simonsen; (12) Sample 552A-5-1, $90 \mathrm{~cm}$, length $17 \mu \mathrm{m}$; (13) Sample 552A-5-1, $90 \mathrm{~cm}$, length $21 \mu \mathrm{m}$; (14) Sample 552A-5-1, $90 \mathrm{~cm}$, length $39 \mu \mathrm{m}$. 16. Coscinodiscus nodulifer Schmidt. Sample 552A-10-2, 110-113 cm, length 39 $\mu \mathrm{m}$. 17, 18. Coscinodiscus nodulifer var. cyclopus Jousé; (17) Sample 552A-16-1, 130-131 cm, length 53 $\mu \mathrm{m}$; (18) Sample 552A-15-3, 100-101 $\mathrm{cm}$, length $33 \mu \mathrm{m}$. 

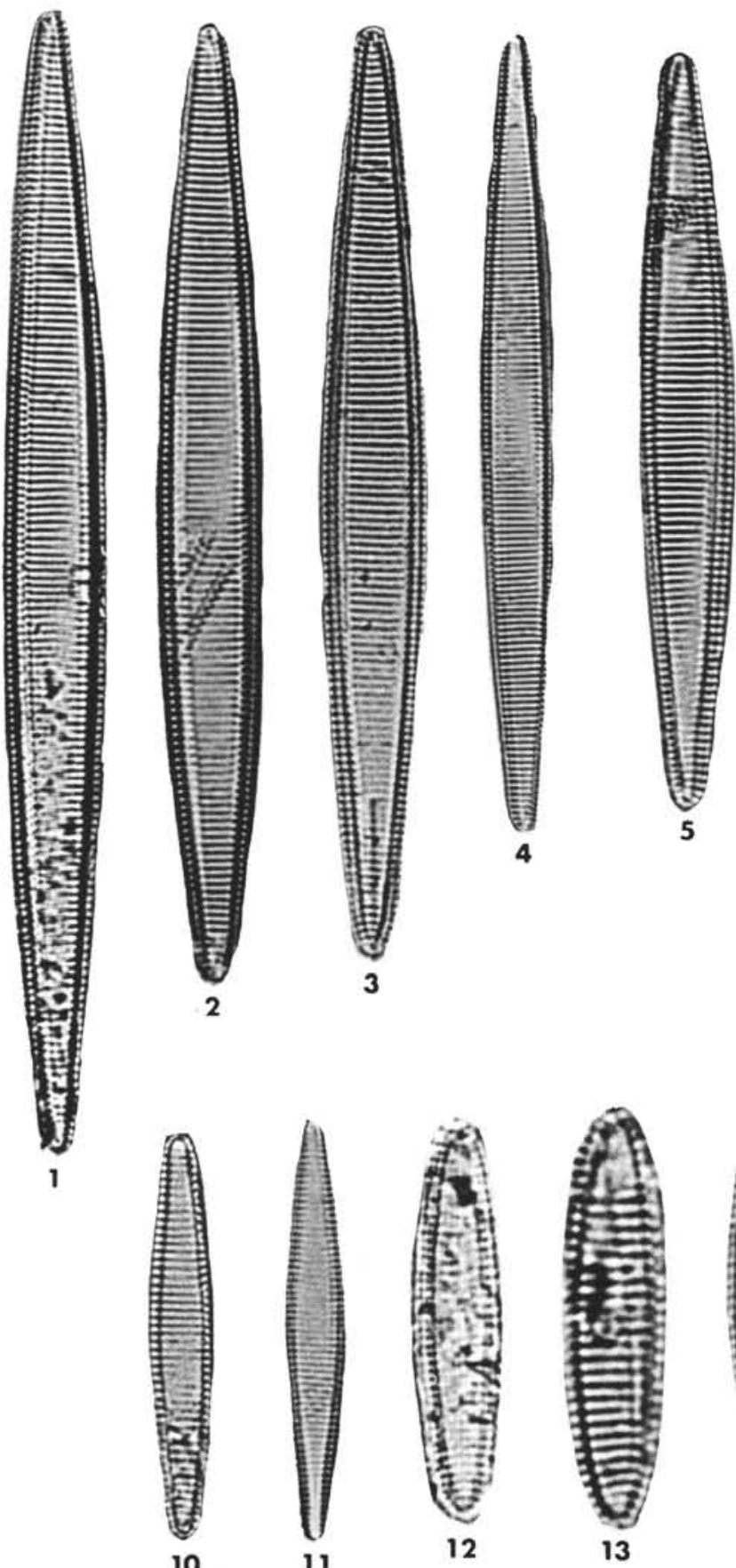


Plate 4. 1-4. Nitzschia marina-Nitzschia reinholdii; (1) Sample 552A-10-2, 34-35 cm, length $96 \mu \mathrm{m}$; (2) Sample 552A-15-3, 100-101 cm, length $100 \mu \mathrm{m}$; (3) Sample 552A-10-2, 130-133 cm, length $79 \mu \mathrm{m}$; (4) Sample 552A-16-1, 130-131 cm, length $88 \mu \mathrm{m}$. 5-7. Nitzschia reinholdii Kanaya and Koizumi; (5) Sample 552A-15-3, 100-101 cm, length $67 \mu \mathrm{m}$; (6) Sample 552A-10-2, 130-133 cm, length 56 $\mu$ m; (7) Sample 552A-10-3, 40-43 $\mathrm{cm}$, length $66 \mu \mathrm{m} . \quad 8,10,11,14,15$. Nitzschia fossilis (Frenguelli) Kanaya; (8) Sample 552A-5-1, $90 \mathrm{~cm}$, length $62 \mu \mathrm{m}$; (10) Sample 552A-15-3, $100-101 \mathrm{~cm}$, length $39 \mu \mathrm{m}$; (11) Sample 552A-15-3, 100-101 cm, length $45 \mu \mathrm{m}$; (14) Sample 552A-5-1, $90 \mathrm{~cm}$, length $21 \mu \mathrm{m}$; (15) Sample 552A-19$3,95-96 \mathrm{~cm}$, length $33 \mu \mathrm{m}$. 16, 17. Nitzschia cf. fossilis (Frenguelli) Kanaya; (16) Sample 552A-19-3, 95-96 cm, length $39 \mu \mathrm{m}$; (17) Sample $552 \mathrm{~A}-19-3,95-96 \mathrm{~cm}$, length $33 \mu \mathrm{m}$. 9. Opephora sp. 1. Sample 552A-16-1, 130-131 cm, length $106 \mu \mathrm{m}$. 12. Nitzschia sp. 1. Sample 552A-93, 33-34 cm, length $28 \mu \mathrm{m}$. 13, 18. Nitzschia cf. cylindrica Burckle; (13) Sample 552A-19-3, 33-34 cm, length $31 \mu \mathrm{m}$; (18) Sample 552A-19-3, 95-96 cm, length $28 \mu \mathrm{m}$. 

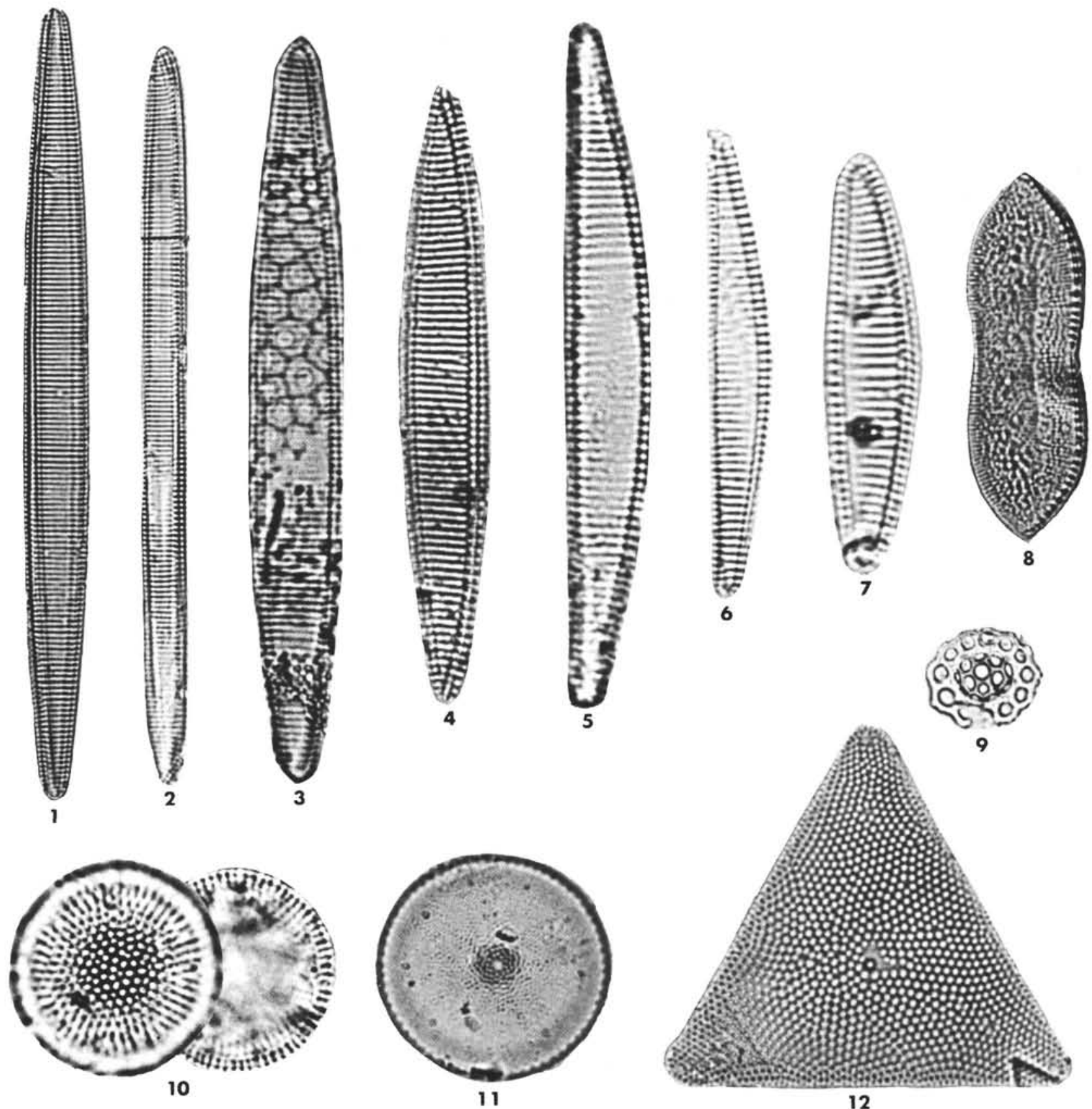

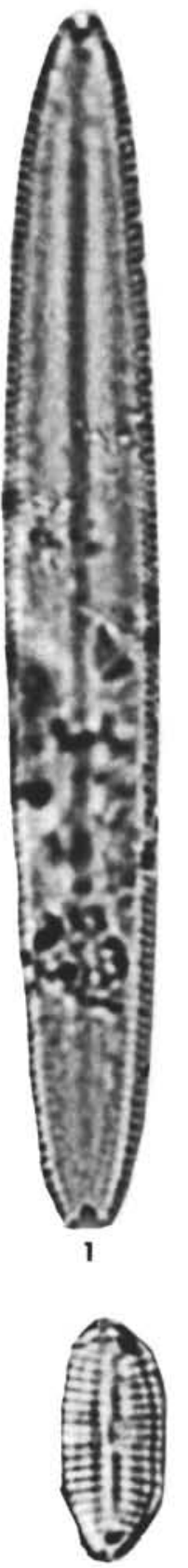

9

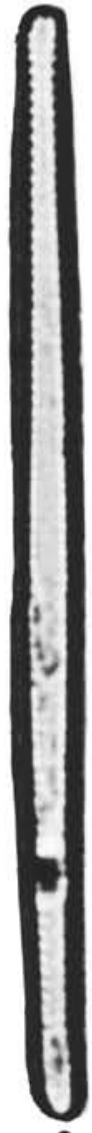

2

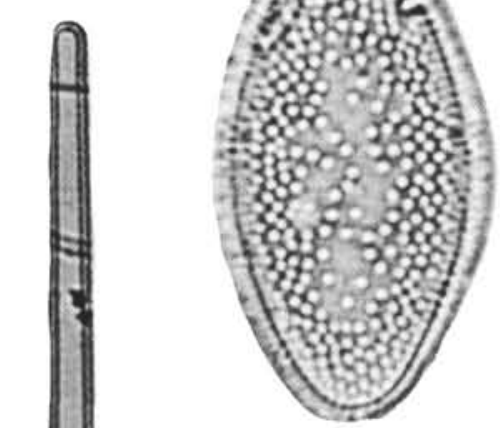

4
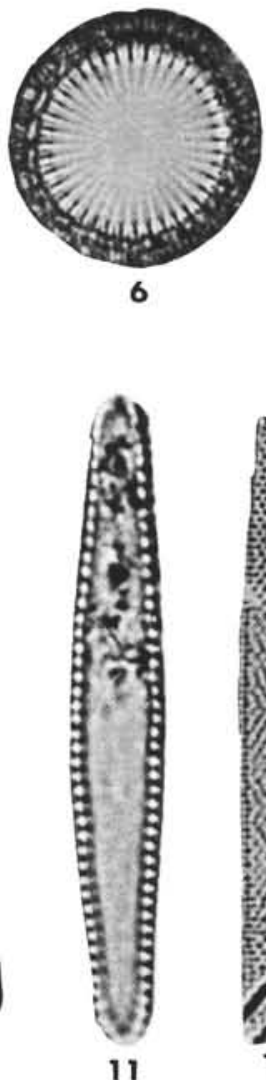
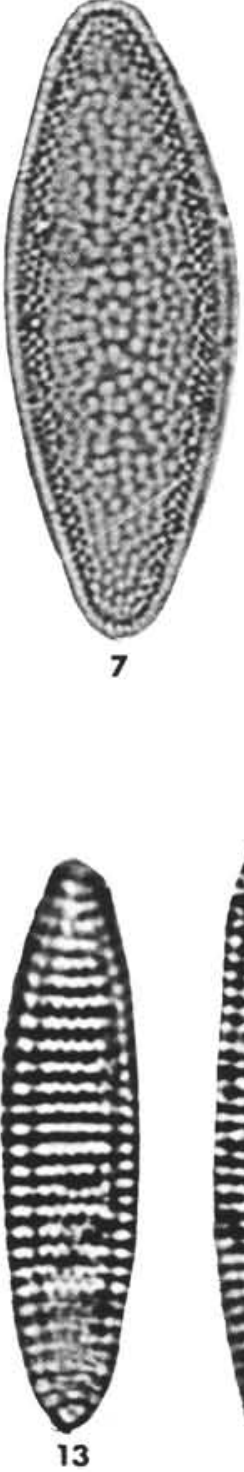

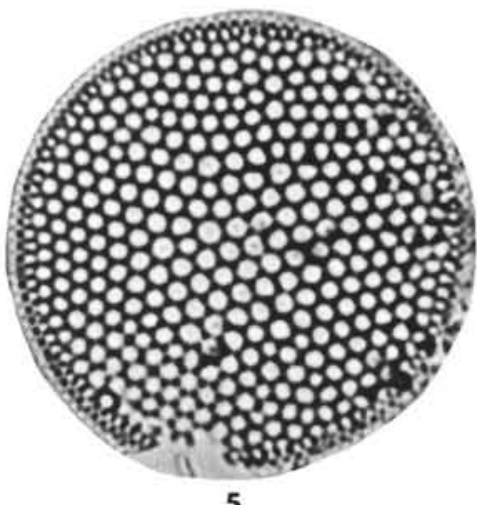

5

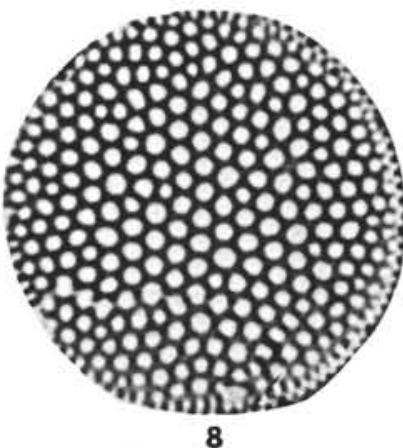

8
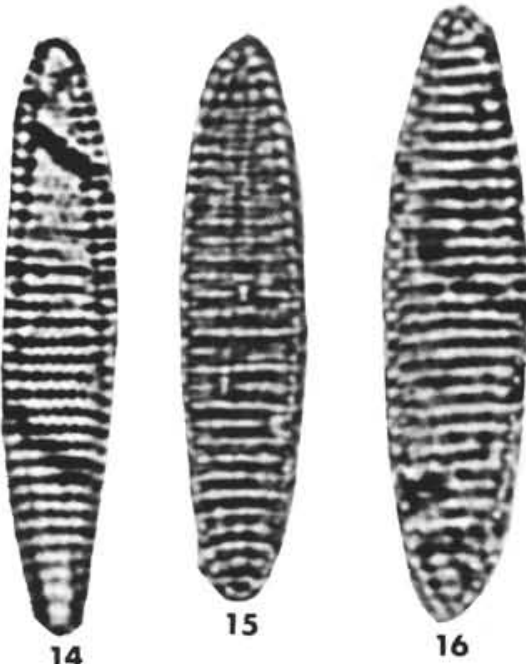

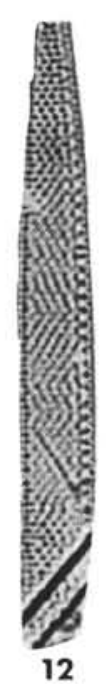

Plate 6. 1. Synedra jouseana Sheshukova-Poretzkaya. Sample 553A-8,CC, length $190 \mu \mathrm{m} . \quad 2,3$. Thalassionema nitzschoides Grunow; (2) Sample 552A-10-1, 130-133 cm, length $84 \mu \mathrm{m}$; (3) Sample 552A-15-3, 100-101 cm, length $80 \mu \mathrm{m}$. 4, 7. Actinocyclus ellipticus Grunow; (4) Sample $552 \mathrm{~A}-19-3,95-96 \mathrm{~cm}$, length $28 \mu \mathrm{m}$; (7) Sample 552A-25-2, 110-111 cm, length $58 \mu \mathrm{m}$. 5, 8. Roperia tesselata (Roper) Grunow; (5) Sample $552 \mathrm{~A}-5-1,90 \mathrm{~cm}$, length $34 \mu \mathrm{m}$; (8) Sample 552A-5-1, $90 \mathrm{~cm}$, length $28 \mu \mathrm{m}$. $\quad$ 6. Melosira sulcata (Ehrenbergii) Kutzing. Sample 553A-11-5, 42$43 \mathrm{~cm}$, length $14 \mu \mathrm{m}$. 9. Navicula sp. 1. Sample 552A-10-3, 61-62 cm, length $9 \mu \mathrm{m}$. 10. Stephanopyxis turris (Greville and Arnott) Ralfs. Sample 552A-10-2, 130-133 cm, length $28 \mu \mathrm{m}$. 11. Thalassionema sp. 1. Sample 555-19-1, 76-77 cm, length $36 \mu \mathrm{m}$. 12. Nitzschia sp. 2 . Sample 552A-15-3, 100-101 cm, length $42 \mu \mathrm{m}$. 13, 14. Nitzschia jouseae Burckle; (13) Sample 552A-10-2, 34-35 cm, length 56 $\mu$ m; (14) Sample $552 \mathrm{~A}-15-3,100-101 \mathrm{~cm}$, length $44 \mu \mathrm{m}$. 15. Nitzschia miocenica Burckle. Sample 552A-29,CC, length $30 \mu \mathrm{m}$. 16. Nitzschia aff. miocenica Burckle. Sample 552A-29,CC, length $31 \mu \mathrm{m}$. 


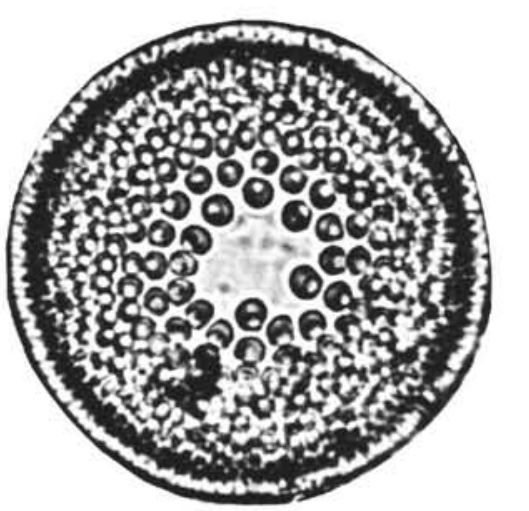

1

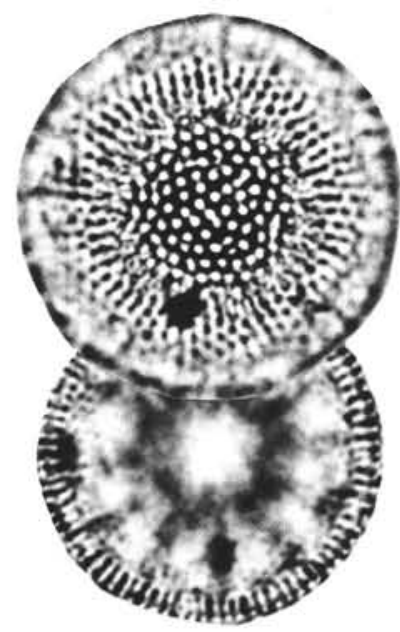

4

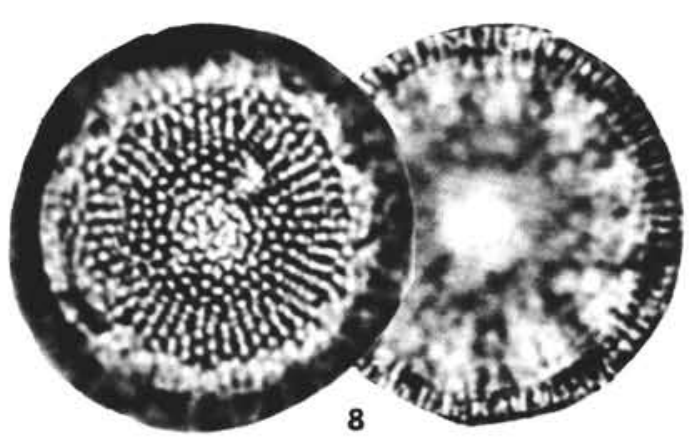

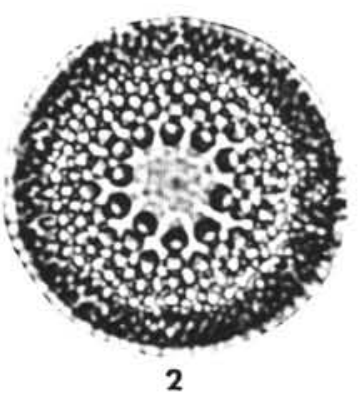
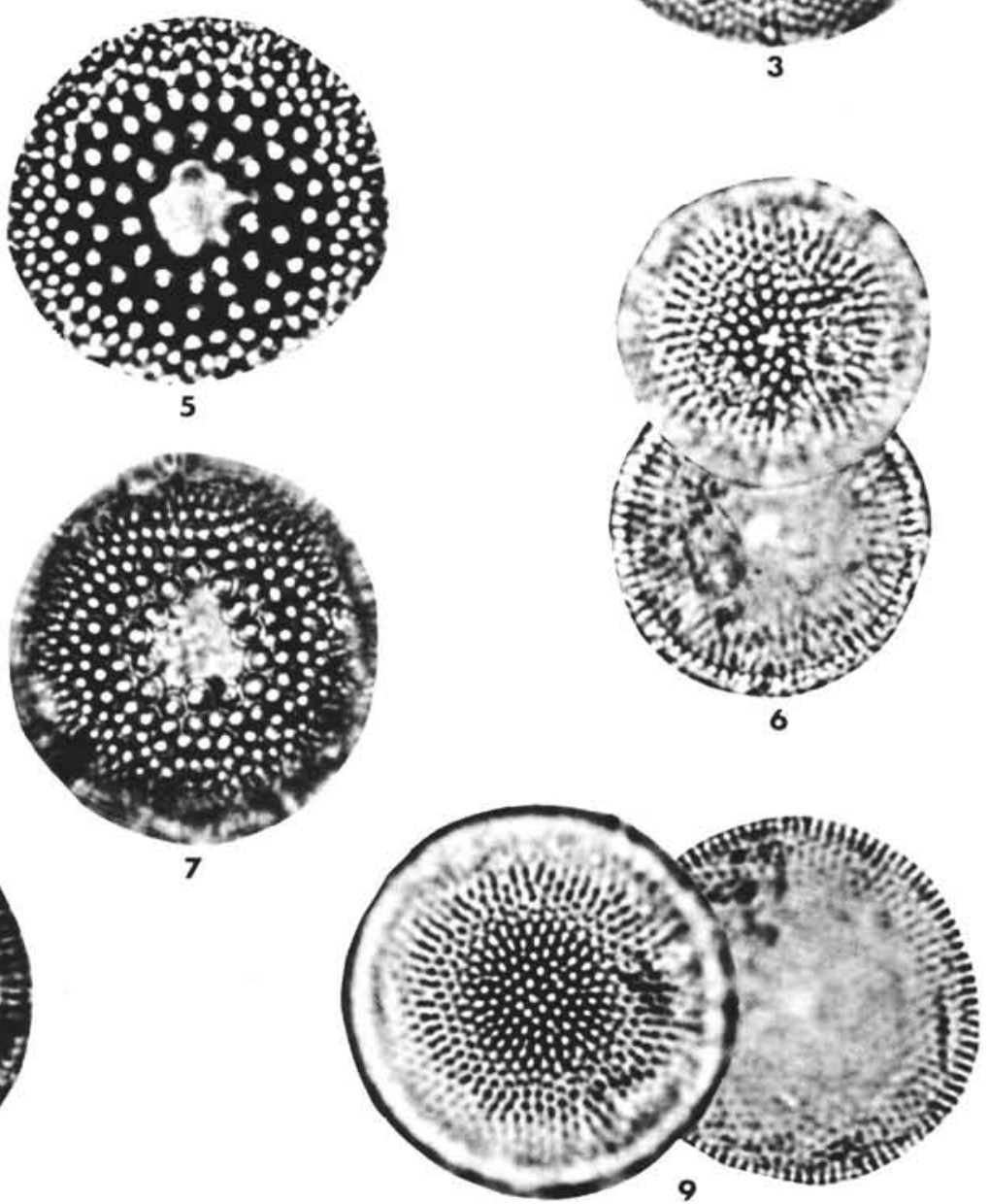

Plate 7. 1, 2, 5, 7. Actinocyclus ingens Rattray; (1) Sample 555-17,CC, $42 \mu \mathrm{m}$; (2) Sample 408-29-2, 94-96 cm, $37 \mu \mathrm{m}$; (5) Sample 553A-7,CC, length $22 \mu \mathrm{m}$; (7) Sample 555, 17,CC length $37 \mu \mathrm{m}$. 3. Actinocyclus ehrenbergii Ralfs. Sample 552A-19-3, 95-96 cm, length $25 \mu \mathrm{m}$. 4, 8. Thalassiosira convexa Muchina; (4) Sample 552A-10-2, 130-133 cm, length $28 \mu \mathrm{m}$; (8) Sample 552A-10-2, 34-35 cm, length $31 \mu \mathrm{m}$. 6, 9. Thalassiosira convexa var. aspinosa Schrader. (6) Sample 553A-1,CC, length $18 \mu \mathrm{m}$; (9) Sample 552A-10-2, 130-133 cm, length $31 \mu \mathrm{m}$. 

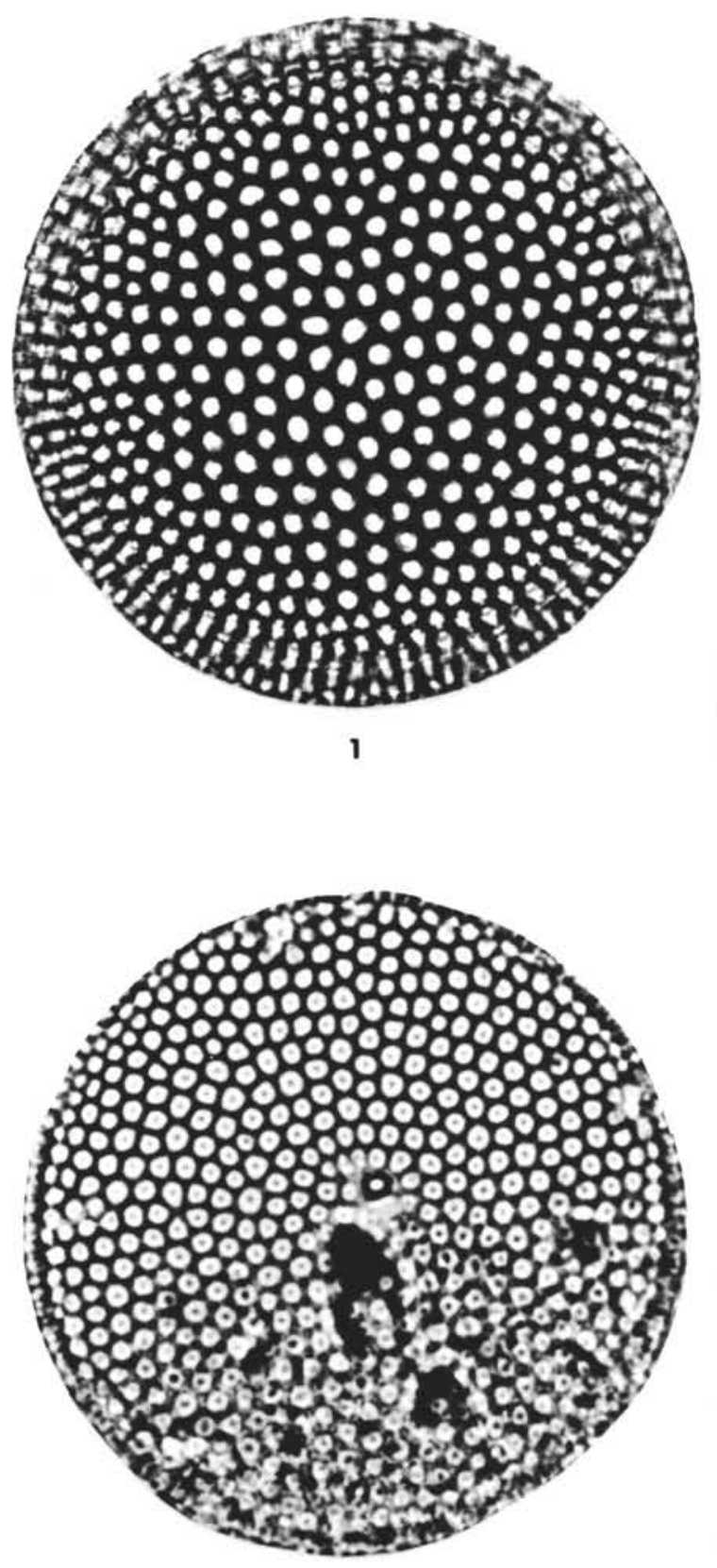

6

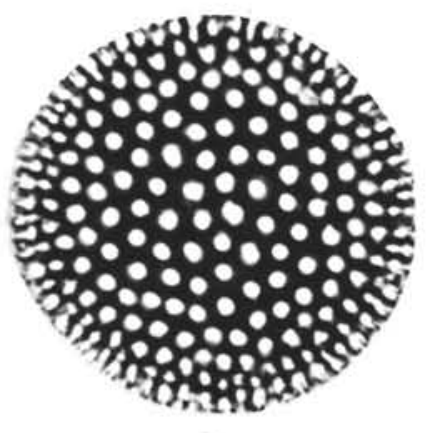

2

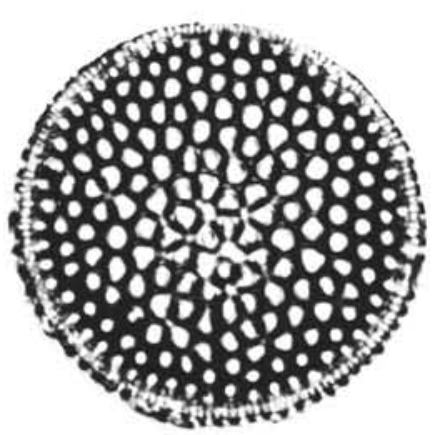

4

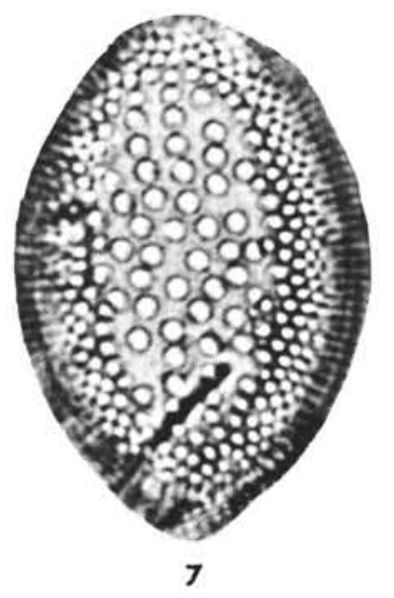

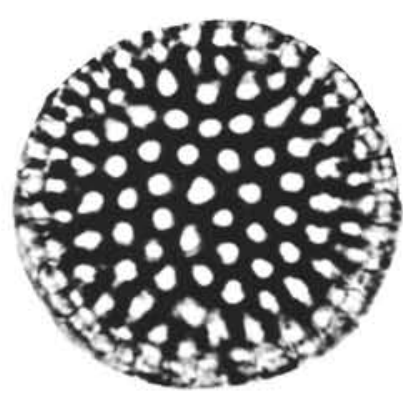

3



5

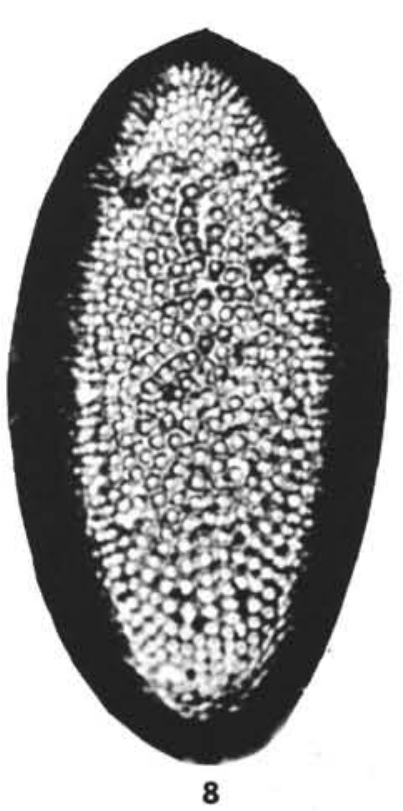

Plate 8. 1-3. Coscinodiscus marginatus Ehrenberg; (1) Sample 552A-10-2, 110-113 cm, length $109 \mu \mathrm{m}$; (2) Sample 552A-9-3, 33-34 cm, length 28 $\mu \mathrm{m}$; (3) Sample 552A-9-4, 23-24 cm, length $22 \mu \mathrm{m}$. 4. Coscinodiscus sp. 1. Sample 552A-9-3, 33-34 cm, length $31 \mu \mathrm{m}$. 5. Coscinodiscus yabei Kanaya. Sample 555-19-1, 76-77 cm, length $18 \mu \mathrm{m}$. 6. Coscinodiscus nodulifer Schmidt. Sample 553A-1-2, $55-56 \mathrm{~cm}$, length $56 \mu \mathrm{m}$. 7. Cascinodiscus lewisianus Greville. Sample 408-29-2, 94-96 cm, length $42 \mu \mathrm{m}$. 8. Coscinodiscus cf. lewisianus? Greville. Sample 555-22-1, 106-107 cm, length $62 \mu \mathrm{m}$. 

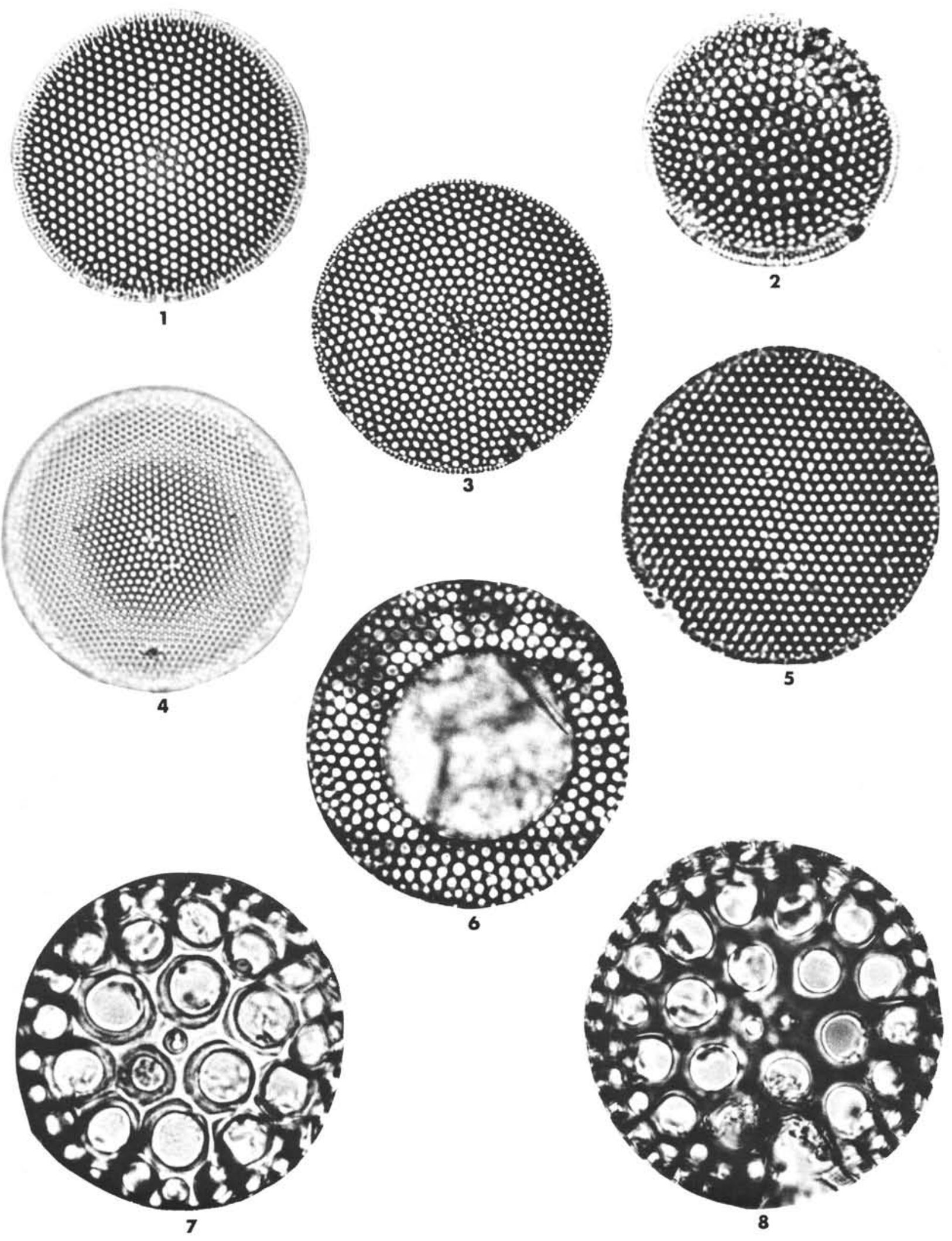

Plate 9. 1, 4. Thalassiosira eccentrica (Ehrenberg) Cleve; (1) Sample 552A-10-2, 34-35 cm, length $36 \mu \mathrm{m}$; (4) Sample 552A-19-3, 95-96 cm, length $31 \mu \mathrm{m}$. 2. Thalassiosira sp. 3. Sample 553A-11-5, $42-43 \mathrm{~cm}$, length $28 \mu \mathrm{m}$. 3. Actinocyclus divisus (Grunow) Hasle and Fryxell. Sample 55519-1, 76-77 cm, length $56 \mu \mathrm{m}$. 5. Thalassiosira leptopus (Grunow) Hasle and Fryxell. Sample 553A-1,CC, length $48 \mu \mathrm{m}$. 6. Craspedodiscus coscinodiscus Ehrenberg. Sample 555-19-1, 76-77 cm, length $65 \mu \mathrm{m}$. 7, 8. Rocella gelida (Mann) Bukry; (7) Sample 553A-9-4, 67-68 cm, length 50 $\mu \mathrm{m}$; (8) Sample 553A-9-4, 67-68 cm, length $71 \mu \mathrm{m}$. 

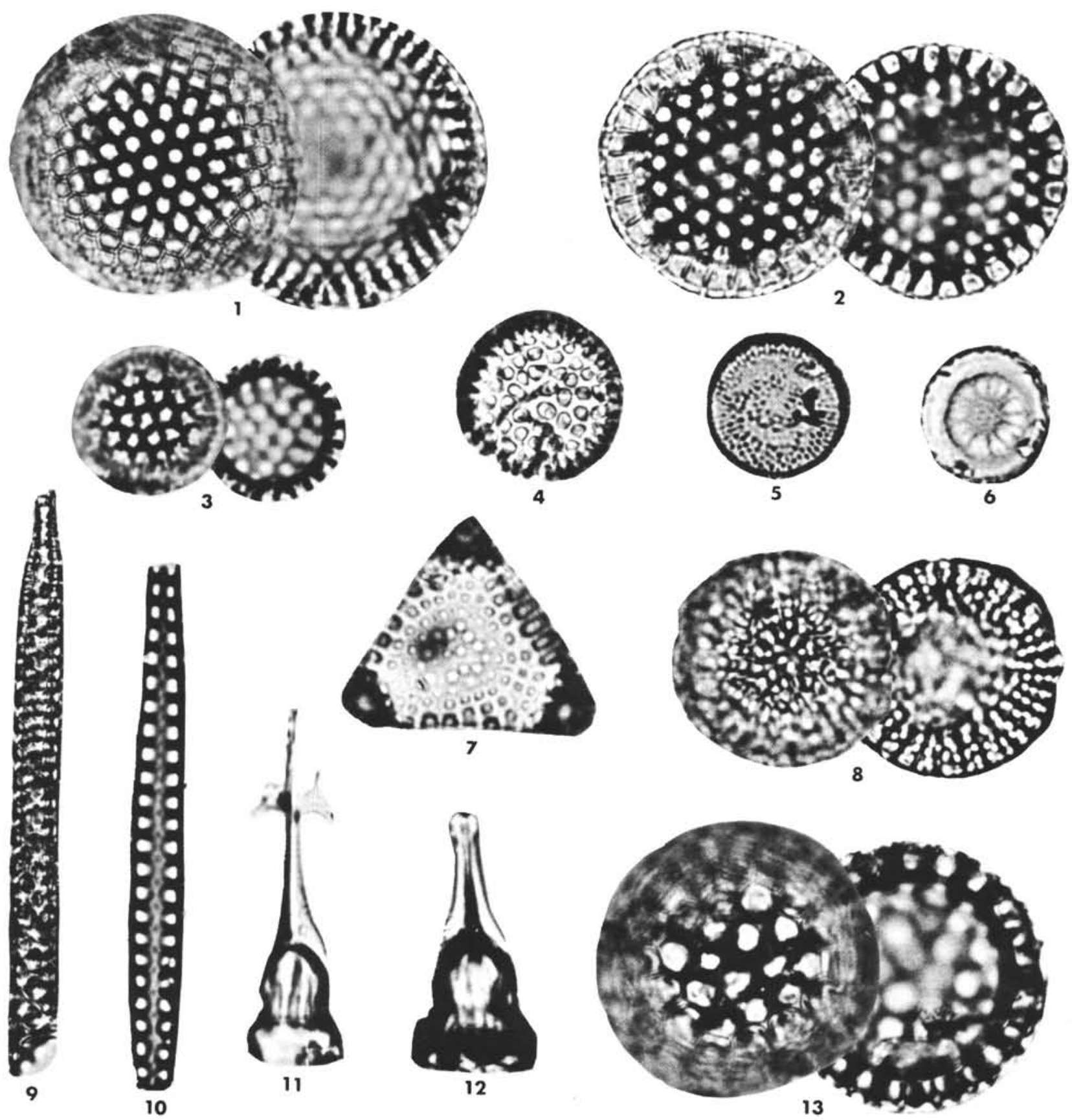

Plate 10. 1. Stephanopyxis sp. 1. Sample 553A-11-5, $42-43 \mathrm{~cm}$, length $33 \mu \mathrm{m}$. 2. Stephanopyxis grunowii Grove et Sturt. Sample 553A-11-5, 42$43 \mathrm{~cm}$, length $30 \mu \mathrm{m}$. 3, 13. Stephanopyxis turris var. cylindrus Grunow; (3) Sample 553A-11-5, $42-43 \mathrm{~cm}$, length $42 \mu \mathrm{m}$; (13) Sample 553A-11$4,131 \mathrm{~cm}$, length $24 \mu \mathrm{m}$. 4. Coscinodiscus praenitidus Fenner. Sample 553A-8,CC, length $13 \mu \mathrm{m}$. 5. Melosira cf. architecturalis Brun. Sample $553 \mathrm{~A}-11-4,131 \mathrm{~cm}$, length $12 \mu \mathrm{m}$. 6. Podosira bella Strenlnikova. Sample $553 \mathrm{~A}-11-4,131 \mathrm{~cm}$, length $8 \mu \mathrm{m}$. 7. Trinacria sp. 1. Sample 553A-9,CC, length $20 \mu \mathrm{m}$. 8. Stictodiscus angulatus Grunow et Moller. Sample 553A-11-4, $131 \mathrm{~cm}$, length $75 \mu \mathrm{m}$. 9. Pyxilla renticulata Grove et Sturt. Sample 553A-11-4, $131 \mathrm{~cm}$, length $113 \mu \mathrm{m}$. 10. Sceptroneis gemmata Grunow. Sample 553A-11-4, $131 \mathrm{~cm}$, length $34 \mu \mathrm{m}$. 11, 12. Pterotheca aculeifera (Grunow) Van Heurck; (11) Sample 553A-11-4, $131 \mathrm{~cm}$, length $39 \mu \mathrm{m}$; (12) Sample $553 \mathrm{~A}-11-4,131 \mathrm{~cm}$, length $28 \mu \mathrm{m}$. 

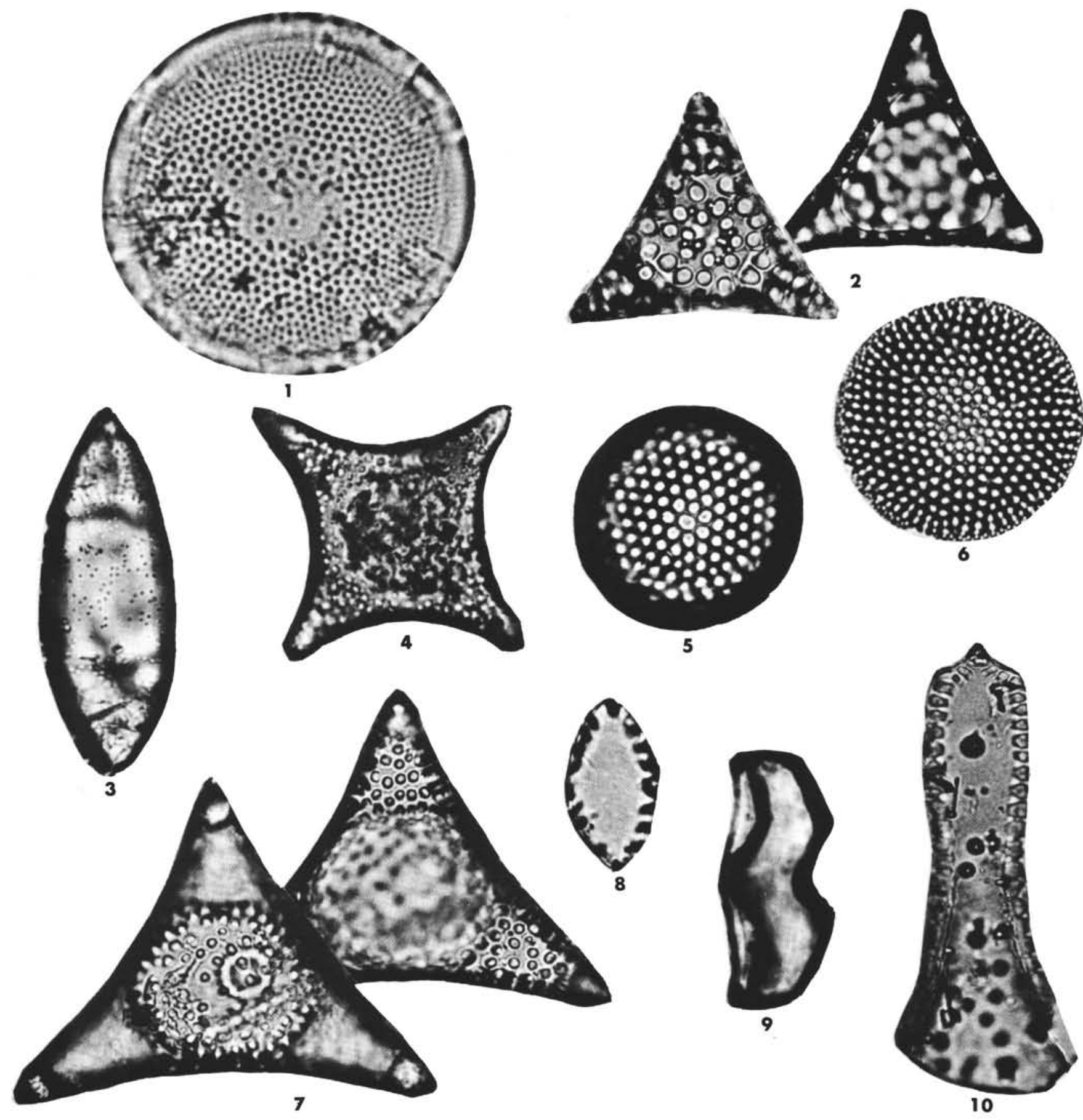

Plate 11. 1. Genus and sp. indet. Sample 553A-1,CC, length $70 \mu \mathrm{m}$. 2. Triceratium sp. 1. Sample $553 \mathrm{~A}-11-4,131 \mathrm{~cm}$, length $28 \mu \mathrm{m}$. 3. Goniothecium odontells Ehrenberg. Sample 553A-11-4, $131 \mathrm{~cm}$, length $33 \mu \mathrm{m}$. 4. Trinacria excavata var. tatragona Schmidt. Sample 552A, 9,CC, length $44 \mu \mathrm{m}$. 5. Stephanopyxis sp. 2. Sample 553A-8,CC, length $25 \mu \mathrm{m}$. 6. Genus and species indet. Sample $553 \mathrm{~A}-11-5,42-43 \mathrm{~cm}$, length 32 $\mu \mathrm{m}$. 7. Triceratium sp. 2. Sample $533 \mathrm{~A}-11-4,131 \mathrm{~cm}$, length $37 \mu \mathrm{m}$. 8. Genus and species indet. Sample $553 \mathrm{~A}-11-4,131 \mathrm{~cm}$, length $18 \mu \mathrm{m}$. 9. Genus and species indet. Sample 553A-9,CC, length $42 \mu \mathrm{m}$. 10. Trinacria simulacrum Grove et Sturt. Sample 553A-11-4, length $77 \mu \mathrm{m}$. 

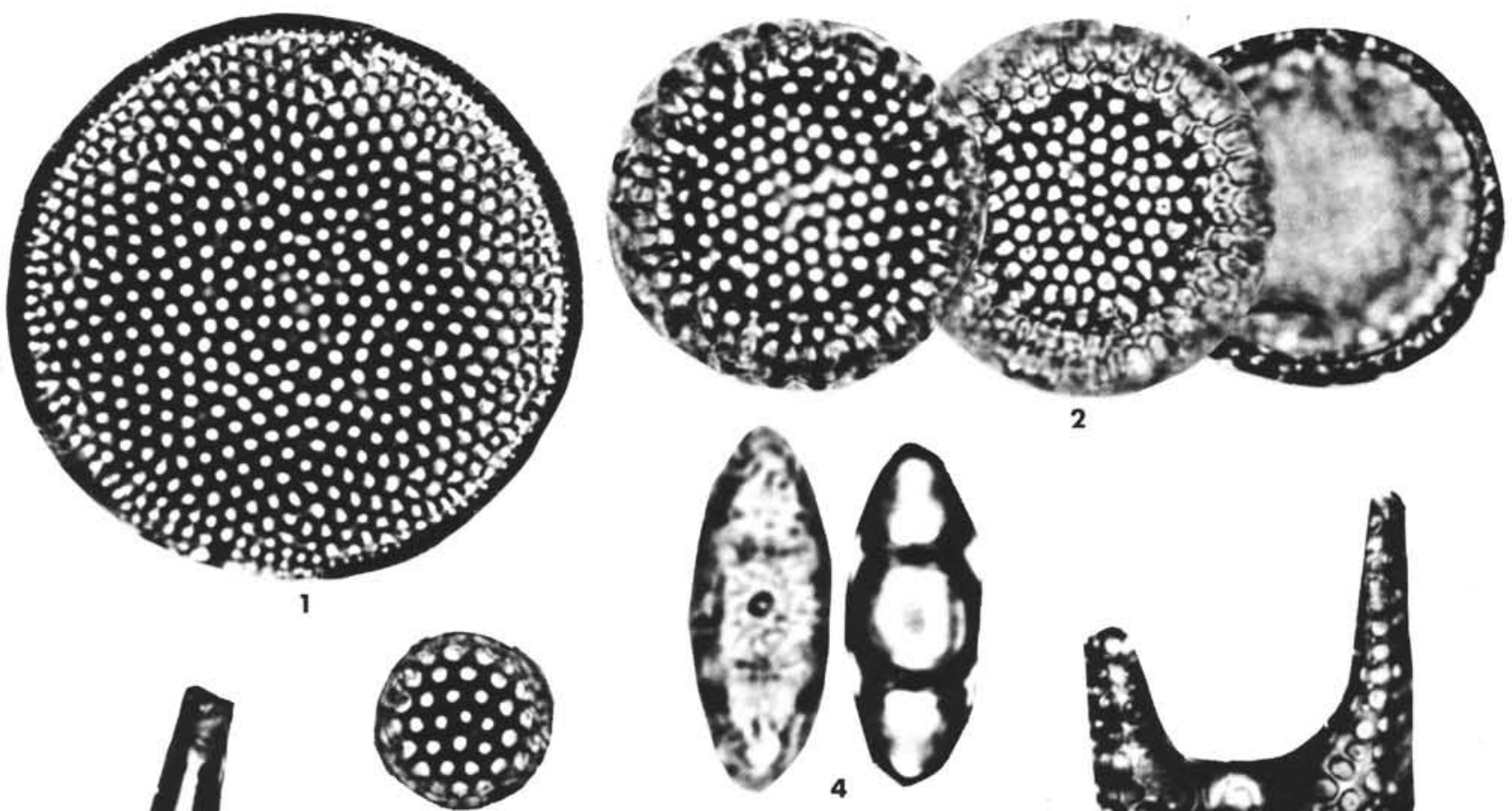

2

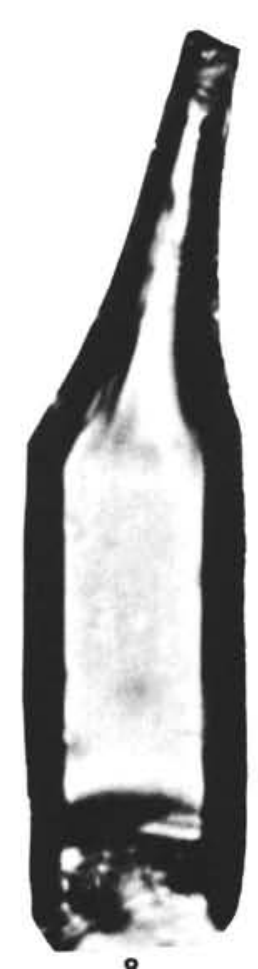

8
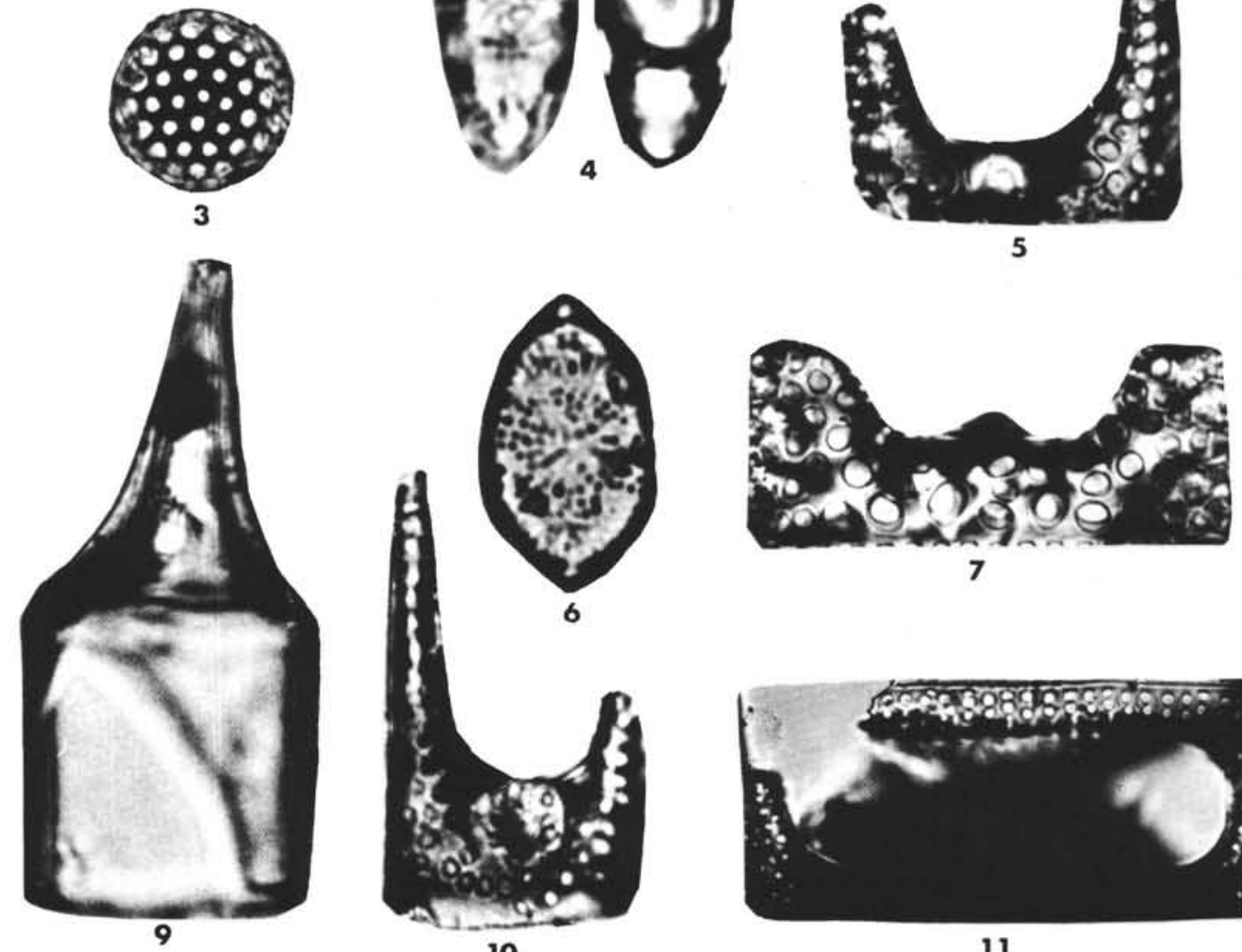

7

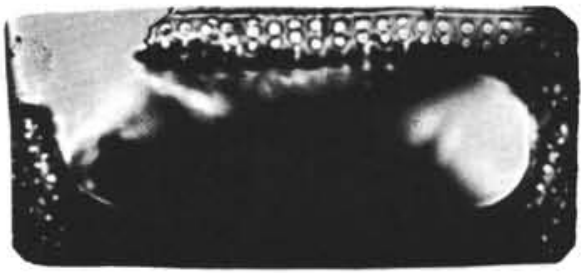

11

Plate 12. 1. Genus and species indet. Sample 553A-11-5, $42-43 \mathrm{~cm}$, length $48 \mu \mathrm{m}$. 2. Stephanopyxis cf. raeana (Castrance) De Toni. Sample 553A-11-5, $42-43 \mathrm{~cm}$, length $30 \mu \mathrm{m}$. 3. Stephanopyxis sp. 3. Sample 553A-11-4, $131 \mathrm{~cm}$, length $11 \mu \mathrm{m}$. 4. Genus and species indet. Sample $553 \mathrm{~A}-11-4,131 \mathrm{~cm}$, length $32 \mu \mathrm{m}$. 5, 11. Hemiaulus polycystinorum Ehrenberg; (5) Sample 553A-11-4, $131 \mathrm{~cm}$, length $30 \mu \mathrm{m}$; (11) Sample 553A-11-4, $131 \mathrm{~cm}$, length $40 \mu \mathrm{m}$. 6. Genus and species indet. Sample 553A-11-4, $131 \mathrm{~cm}$, length $5 \mu \mathrm{m}$. 7. Trinacria sp. 1. Sample 553A-11-5$42-43 \mathrm{~cm}$, length $34 \mu \mathrm{m} . \quad 8,9$. Pterotheca danica (Grunow) Forti. (8) Sample 553A-11-4, $131 \mathrm{~cm}$, length $50 \mu \mathrm{m}$. (9) Sample 553A-11-4, 131 cm, length $44 \mu \mathrm{m}$. 10. Hemiaulus sp. 2. Sample 553A-11-4-131 cm, length $40 \mu \mathrm{m}$. 

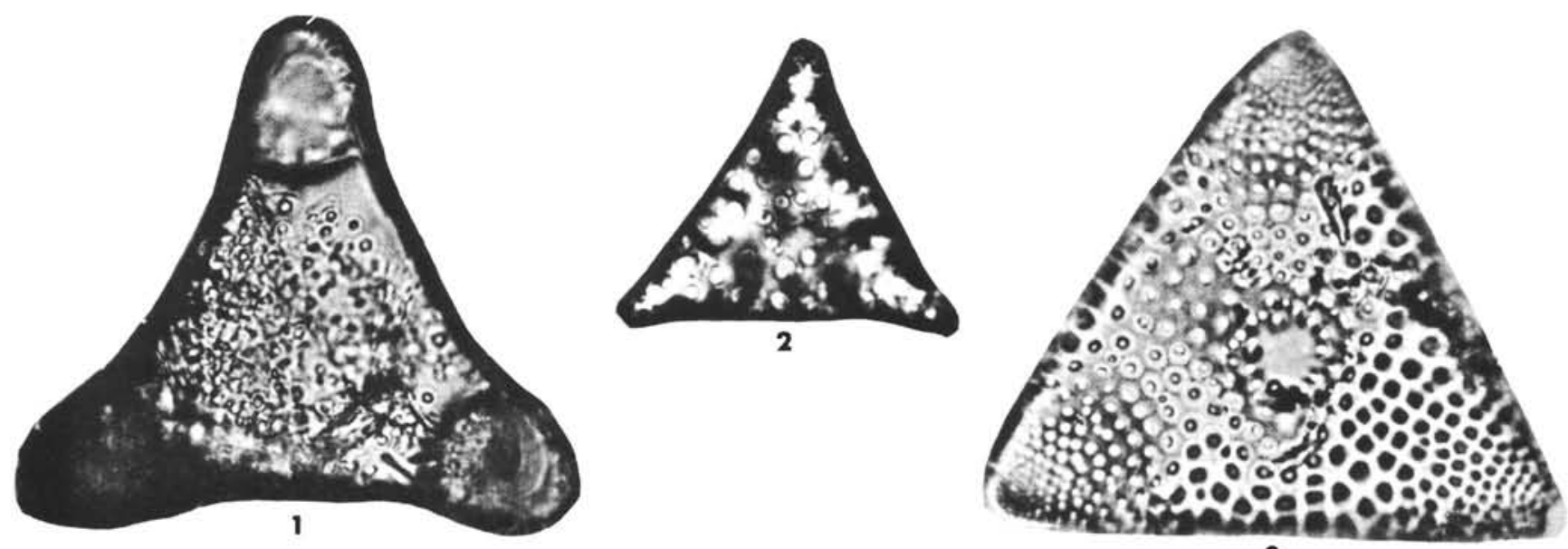

3

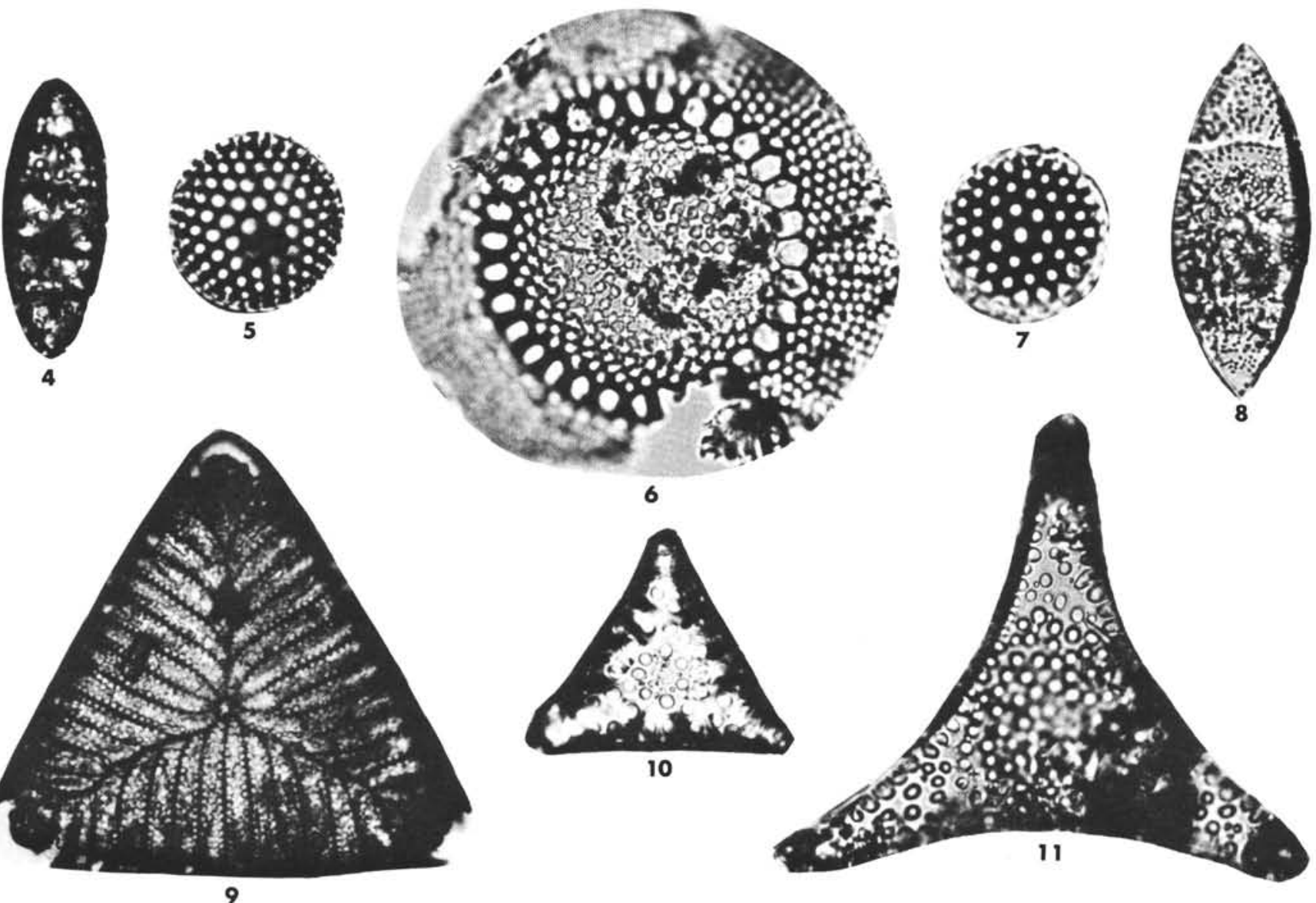

Plate 13. 1. Triceratium cf. imperator Trunn et Witt. Sample 553A-11-4, $131 \mathrm{~cm}$, length $61 \mu \mathrm{m}$. 2. Triceratium sp. 3. Sample 553A-11-4, 131 cm, length $28 \mu \mathrm{m}$. 3. Triceratium cf. pulchrum Hustedt. Sample 553A-11-5, $42-43 \mathrm{~cm}$, length $56 \mu \mathrm{m}$. 4. Hemiaulus sp. 1. Sample 553A-11-4, 131 $\mathrm{cm}$, length $30 \mu \mathrm{m}$. 5. Genus and species indet. Sample 553A-11-4, $131 \mathrm{~cm}$, length $18 \mu \mathrm{m}$. 6. Brightwellia cf. coronata (Brightwell) Ralfs. Sample 552A-9,CC, length $70 \mu \mathrm{m}$. 7. Genus and species indet. Sample 553A-11-4, $131 \mathrm{~cm}$, length $14 \mu \mathrm{m}$. 8. Genus and species indet. Sample $553 \mathrm{~A}-11-4,131 \mathrm{~cm}$, length $43 \mu \mathrm{m}$. 9. Triceratium polycystinorum Pantocsek. Sample 552-10,CC, length $62 \mu \mathrm{m}$. 10. Triceratium sp. 3. Sample $553 \mathrm{~A}-11-5,42-43 \mathrm{~cm}$, length $28 \mu \mathrm{m}$. 11. Trinacria simulacrum Grove et Sturt. Sample 553A-11-4, $131 \mathrm{~cm}$, length $56 \mu \mathrm{m}$. 